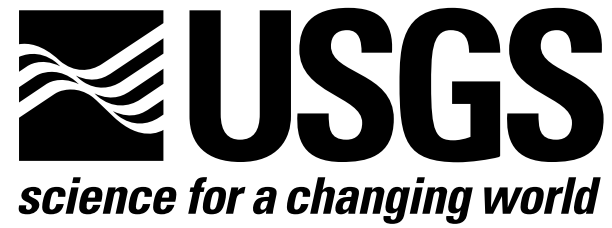

Prepared in cooperation with the MASSACHUSETTS DEPARTMENT OF ENVIRONMENTAL PROTECTION DIVISION OF WATERSHED MANAGEMENT

\section{Statewide Water-Quality Network for Massachusetts}

Water-Resources Investigations Report 01-4081

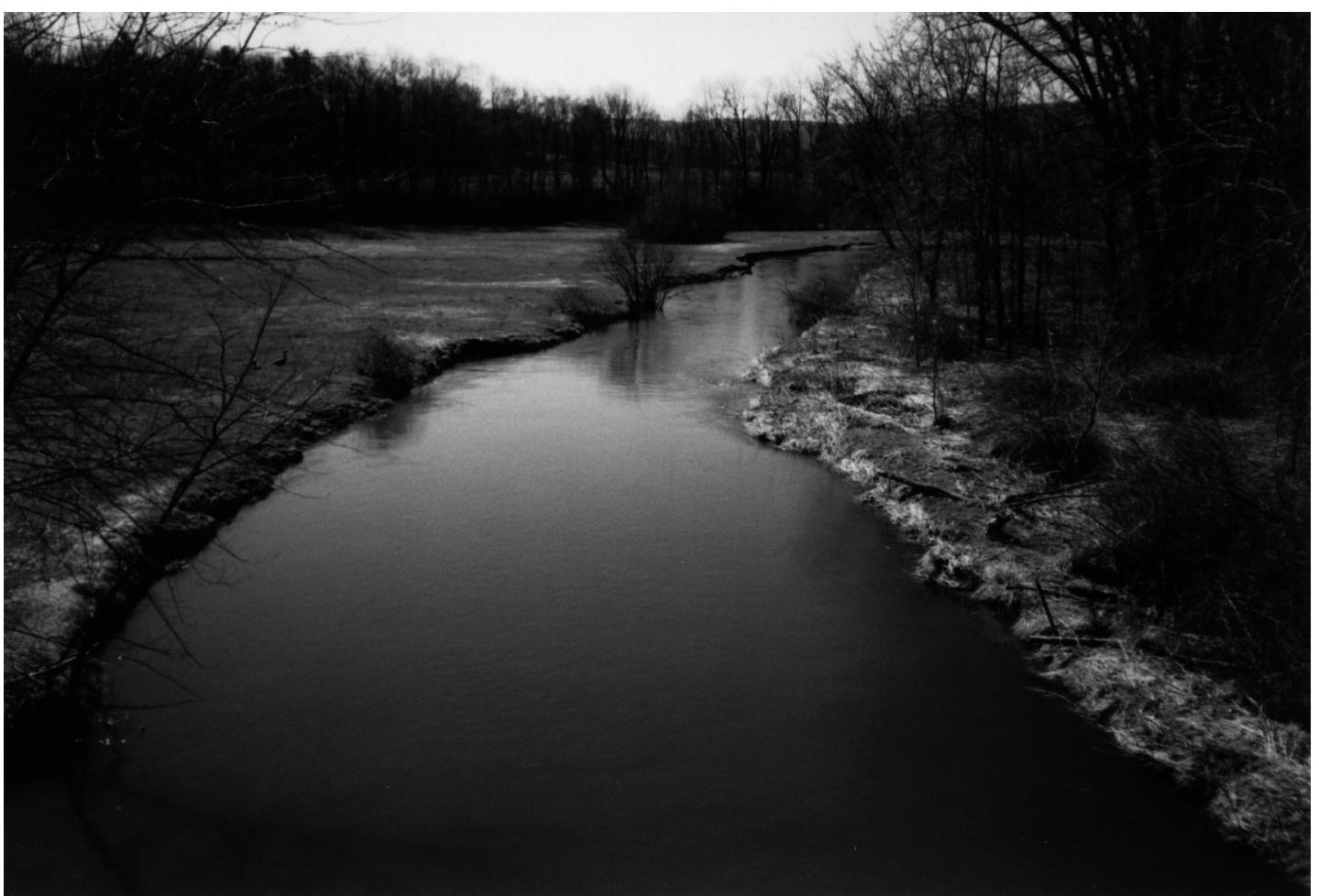

U.S. Department of the Interior

U.S. Geological Survey

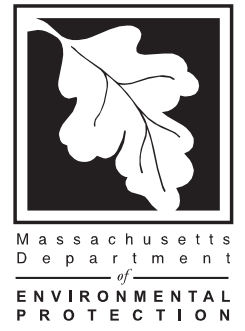

P R OTECTION 
Cover photo is the Konkapot River at Ashley Falls, Sheffield, Massachusetts. Photo by Gardner Bent. 
U.S. Department of the Interior

U.S. Geological Survey

\section{Statewide Water-Quality Network for Massachusetts}

By LESLIE A. DESIMONE, PETER A. STEEVES, and MARC J. ZIMMERMAN

Water-Resources Investigations Report 01-4081

Prepared in cooperation with the

MASSACHUSETTS DEPARTMENT OF ENVIRONMENTAL

PROTECTION, DIVISION OF WATERSHED MANAGEMENT

Northborough, Massachusetts

2001 


\section{U.S. DEPARTMENT OF THE INTERIOR \\ GALE A. NORTON, Secretary}

U.S. GEOLOGICAL SURVEY

Charles G. Groat, Director

The use of trade or product names in this report is for identification purposes only and does not constitute endorsement by the U.S. Government.

For additional information write to:

Chief, Massachusetts-Rhode Island District

U.S. Geological Survey

Water Resources Division

10 Bearfoot Road

Northborough, MA 01532

or visit our Web site at

http://ma.water.usgs.gov
Copies of this report can be purchased from:

U.S. Geological Survey Branch of Information Services

Box 25286

Denver, CO 80225-0286 


\section{CONTENTS}

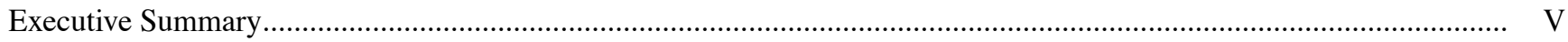

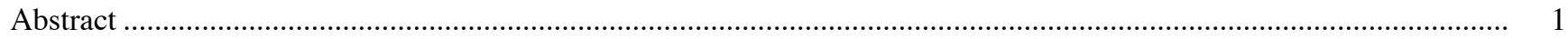

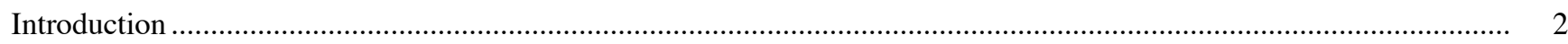

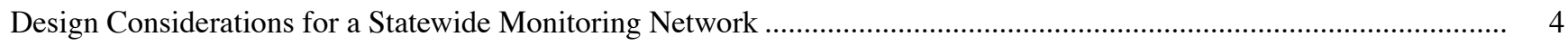

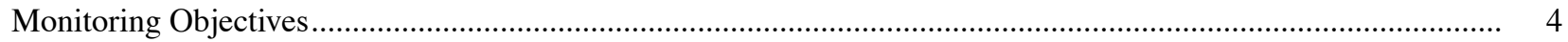

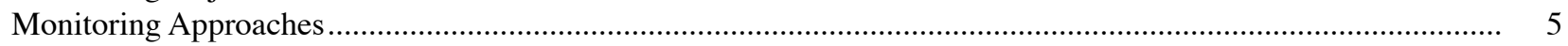

Ongoing Monitoring Activities by State Agencies in Massachusetts.................................................................. 9

Tier I: Basin-Based Monitoring Program for the Clean Water Act Statewide Assessment.............................................. 13

Tier I Monitoring Program Objectives and Approaches ............................................................................. 13

Tier I Monitoring Design for the Neponset River Basin ................................................................................. 17

Definition of Water Resources in the Basin ................................................................................... 17

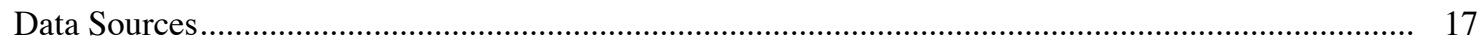

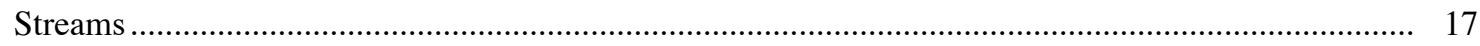

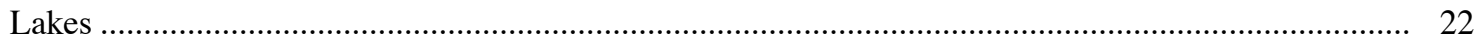

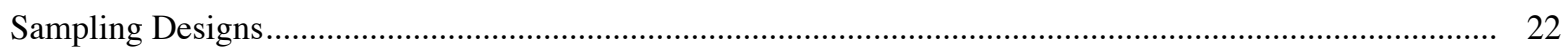

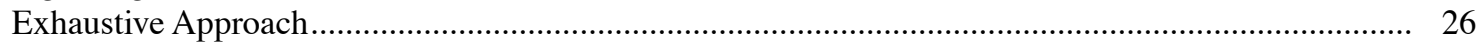

Sampling Sites, Parameters, and Frequency ....................................................................... 26

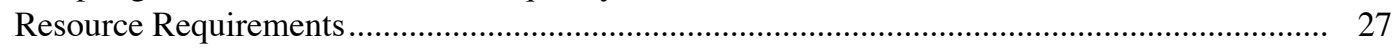

Analysis of the 1994 Neponset Water-Resource Assessment .......................................................................... 30

Combined Probabilistic-Deterministic Approach .............................................................................................. 32

Sampling Sites, Parameters, Frequency, and Resource Requirements for Streams .................................... 32

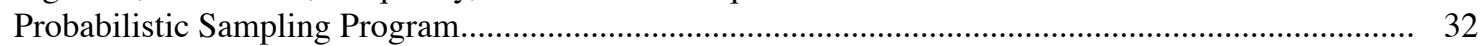

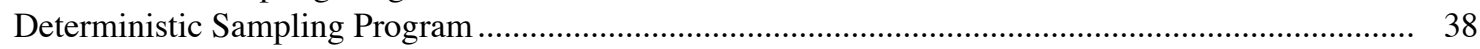

Sampling Sites, Parameters, Frequency, and Resource Requirements for Lakes ......................................... 43

Statewide Implementation of the Combined Probabilistic-Deterministic Approach for Tier I

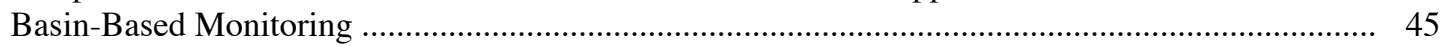

Tier II: Fixed-Station Monitoring Program for Contaminant Loads in Major Rivers...................................................... 47

Sampling Sites, Parameters, and Frequency ……................................................................................... 47

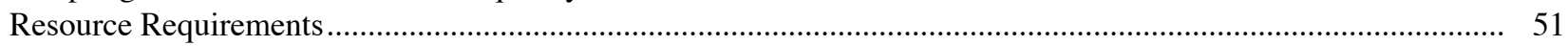

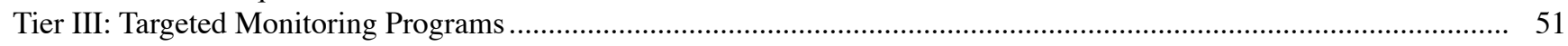

Tier V: Strategies for Compliance-Based Ambient Monitoring ..............................................................................

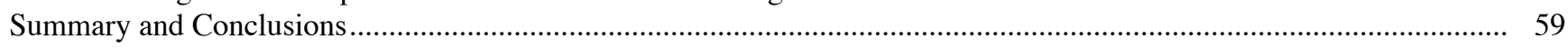

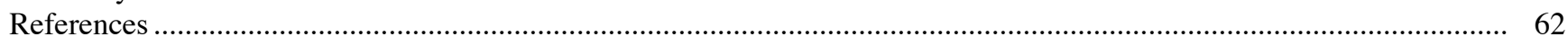

Appendix: Geographic Information System (GIS) and other computer-based procedures used in the monitoring design for the Neponset Basin .............................................................................................. 65

\section{FIGURES}

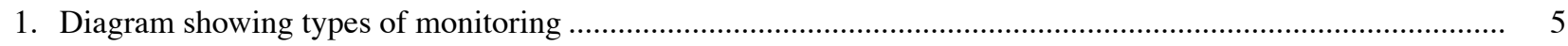

2. Map showing the Neponset Basin in eastern Massachusetts ...................................................................... 18

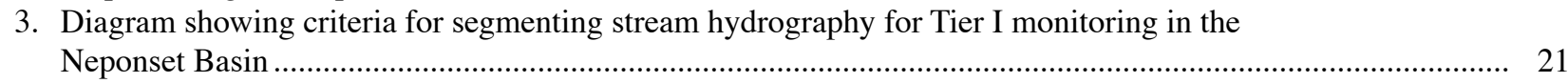

4. Maps showing perennial streams by stream order and lakes inventoried for Tier I monitoring in the Neponset River Basin

5. Diagram showing total perennial stream miles in the Neponset Basin and assessed miles by stream order and designated use from the 1994 Neponset water-resource assessment ................................................ 31

6-8. Maps showing:

6. Locations and watershed-drainage areas of proposed sites for Tier II monitoring

7. Sites sampled for bacteria for hot-spot monitoring in the 1994 Neponset water-resource assessment and generalized land use in the basin ....

8. Locations and watershed-drainage areas of permitted major discharge sites within the National Pollutant Discharge Elimination System in Massachusetts for potential water-quality monitoring 


\section{TABLES}

1. Ongoing water-quality monitoring in Massachusetts by State agencies and programs.

2. Selected surface-water quality standards and criteria for determining use-support status in Massachusetts streams

3. Discharges permitted under the National Pollutant Discharge Elimination System that were used in defining stream segments for Tier I monitoring in the Neponset Basin

4. Summary statistics for stream miles and segments inventoried for Tier I monitoring in the Neponset Basin

5. Physical characteristics of lakes inventoried for Tier I monitoring in the Neponset Basin

6. Sampling parameters and frequency for an exhaustive approach to Tier I monitoring in the Neponset Basin

7. Resource requirements for an exhaustive approach to Tier 1 monitoring in the Neponset Basin

8. Sampling parameters and frequency for a combined probabilistic-deterministic approach to Tier I monitoring in the Neponset Basin.

9. Resource requirements for a combined probabilistic-deterministic approach to Tier 1 monitoring in the Neponset Basin

10. Sampling sites and drainage areas for Tier II monitoring to determine loads carried by major rivers in Massachusetts

11. Distribution of major discharge sites within the National Pollutant Discharge Elimination System among major river basins and stream orders in Massachusetts

\section{CONVERSION FACTORS AND WATER-QUALITY INFORMATION}

CONVERSION FACTORS

\begin{tabular}{rrl}
\hline Multiply & By & To obtain \\
\hline acres & 0.4047 & hectares \\
feet $(\mathrm{ft})$ & 0.3048 & meters \\
miles $(\mathrm{mi})$ & 1.609 & kilometers \\
square miles $\left(\mathrm{mi}^{2}\right)$ & 12.590 & square kilometers \\
Temperature is given in degrees Fahrenheit $\left({ }^{\circ} \mathrm{F}\right)$, which can be converted to \\
degrees Celsius $\left({ }^{\circ} \mathrm{C}\right)$ by the following equation: \\
\multicolumn{2}{c}{$\mathrm{C}=\left({ }^{\circ} \mathrm{F}-32\right) / 1.8$} \\
\hline
\end{tabular}

\section{WATER-QUALITY INFORMATION}

Concentrations of chemical constituents are given in milligrams per liter (mg/L). Milligrams per liter are units expressing the concentration of a chemical constituent in solution as weight (milligrams) of solute per unit volume (liter) of water. For concentrations less than $7,000 \mathrm{mg} / \mathrm{L}$, milligrams per liter is equivalent to "parts per million." 


\section{Statewide Water-Quality Network for Massachusetts}

\section{EXECUTIVE SUMMARY}

\section{Problem}

Public agencies tasked with protecting and managing water resources need information from water-quality monitoring for many purposes. Information is needed to assess the current "health" of water bodies with respect to water-quality standards, to design and evaluate remediation programs, to document compliance with regulations, to detect trends in water quality, to identify emerging problems, and to increase community awareness of waterresource protection. In Massachusetts, several State and Federal agencies and many volunteer groups conduct water-quality monitoring, but their programs do not always provide data at the spatial or temporal scales necessary to meet these information needs. For example, only 18 percent of total stream miles and 48 percent of lake acres were reported as assessed in the State's 1998 Summary of Water Quality [305(b)] report, and statewide trends cannot be determined from the existing data (Commonwealth of Massachusetts, 1997, 1998). Previous statewide data-collection programs have been biased towards larger rivers, known problem areas, and point pollution sources; in this way, the programs have provided limited spatial coverage and have not adequately depicted waterquality conditions throughout the State. A statewide strategy for water-quality monitoring is needed to provide consistent and comprehensive water-quality data on waters throughout the Commonwealth.

\section{Overview}

The U.S. Geological Survey worked with the Massachusetts Department of Environmental Protection, Division of Watershed Management (DEP/DWM) to design a water-quality monitoring program for Massachusetts. The program design was guided by the information needs of the DEP/DWM, which include mandates of the Clean Water Act (CWA) and activities of the Massachusetts Watershed Initiative (MWI), and by input from many organizations involved in water-quality monitoring in the State. To be effective, a monitoring program must be designed to fulfill the purposes for which the data will be used. Thus, the proposed program for Massachusetts' multiple information needs has several components or tiers, that are defined by specific monitoring objectives:

\section{- Tier I-Basin-Based, Statewide Water-Quality} Assessment: To provide a periodic assessment of the water-quality status of the State's surface waters, as required by section 305(b) of the CWA; implemented on a 5-year, rotating-basin basis with the MWI basin assessments;

- Tier II-Contaminant Loads: To determine loads of contaminants carried by major rivers in Massachusetts at strategic locations, such as at the mouths of major rivers and at State boundaries;

- Tier III -Targeted Monitoring, Spatially or by Issue: To identify impaired water bodies required by section 303(d) of the CWA, to determine causes and sources of impairments for purposes of 303(d) and 305(b) requirements, to identify pollution sources or "hot-spots," and other site-specific objectives;

- Tier IV-TMDLs: To develop Total Maximum Daily Loads for specific water bodies.

- Tier V-Compliance monitoring: To meet regulatory requirements and permits.

The program as described in this report is most fully developed for Tiers I and II, which are statewide in scale, and resource requirements for implementing these tiers are discussed. Strategies for Tier III "hotspot monitoring," an objective of the MWI teams, also are investigated. Strategies for Tier IV, TMDL development and monitoring in Massachusetts, are being developed separately and are not discussed in this report. Finally, a network is investigated that would use compliance monitoring under the National Pollutant Discharge Elimination System as a possible fifth Tier in the program. 


\section{Design Considerations}

To guide the monitoring program design, a review was conducted of general principles of network design, including monitoring objectives and approaches, and of ongoing monitoring activities of Massachusetts State agencies. A clear definition of objectives for the monitoring program is a first and necessary step in network design. Monitoring approaches, which comprise the details of how waterquality measurements will be made, are chosen to answer the water-quality questions posed by the program objectives. Monitoring approaches can be defined in terms of the time period of the measurements (shortterm, long-term, or rotating), the method of site selection (targeted or probabilistic), the types of measurements made (for example, physical, chemical, or biological), the type of water resource being monitored (for example, stream, lake, or ground water), and the use of the monitoring results. Monitoring methods include fixed-station monitoring, which is a type of monitoring in which the same sites are repeatedly sampled at regular intervals, for a long period of time. Fixed-station monitoring and flow data typically are needed to estimate mass fluxes or constituent loads, as in Tier II of the proposed monitoring program; this is not the best approach for a large-scale assessment of water-resource conditions, as is needed for Tier I of the proposed program. Short-term (synoptic) surveys that incorporate probabilistic designs are more appropriate for large-scale assessments.

Ongoing monitoring programs by State agencies include (1) lake sampling, fish-toxics monitoring, benthic macroinvertebrate measurements, and some water-chemistry monitoring by DEP/DWM, (2) lake monitoring by DEM in State parks, (3) reservoir, reservoir tributary, and coastal river sampling for bacteria and water-chemistry by the Metropolitan District Commission and the Massachusetts Water Resources Authority, (4) bacteria and physical monitoring in coastal waters by the Division of Marine Fisheries and fish community surveys by the Division of Fisheries and Wildlife of the Department of Fisheries, Wildlife, and Environmental Law Enforcement, (5) groundwater monitoring for highway-runoff contaminants by the Massachusetts Highway Department, and (6) diverse monitoring activities of many local volunteer groups. Many of these activities would provide useful data for components of the statewide monitoring program, but none has the monitoring approach, geographic coverage, sampling density, or sampling parameters that would provide information to meet all the information needs of DEP/DWM, the MWI teams, and the U.S. Environmental Protection Agency. The review of ongoing monitoring programs demonstrates the need for the development of a statewide monitoring program.

\section{Statewide Water-Quality Network Design}

\section{Tier I-Basin-Based, Statewide Water-Quality Assessment}

The proposed monitoring program developed for Tier I objectives consists of a basin-based assessment of existing surface-water-quality conditions with respect to State water-quality standards and the designated uses of water bodies. Requirements for a Tier I program, reflecting CWA mandates, are that it be statewide in scale, comprehensive (all water bodies in the Commonwealth are assessed), and repeated at regular intervals. Another goal is that the program lead to improvements in the 305(b) assessment, by increasing the number of stream miles and lake acres assessed and reducing the historical bias toward problem areas. Monitoring for Tier I objectives would be implemented on a 5-year, rotating basin basis, reflecting the State's strong commitment to the watershed approach. Several approaches for this tier were investigated by use of information collected in the Neponset Basin in eastern Massachusetts. This basin was also used as a pilot area for the MWI in the early 1990s. The Neponset Basin is a 117-square-mile watershed with urban (19 percent), residential (35 percent), and forested or undeveloped (48 percent) land uses that drains to Boston Harbor.

Geographic Information System (GIS) procedures were developed to inventory streams and lakes in the Neponset Basin for a comprehensive assessment using the 1:25,000-scale centerline hydrography and Watershed Tools of the Massachusetts Office of Geographic and Environmental Information (MassGIS). The basin contains 152 miles of perennial streams and 46 lakes larger than 5 acres for inclusion in the assessment. About 50 percent of stream miles were firstorder, or small headwater, streams; about 35 percent were second- or third-order streams, many of which drain major tributary subbasins; and about 15 percent were fourth- and fifth-order streams, primarily parts of the mainstem Neponset and East Branch Neponset Rivers. 
In order to investigate an exhaustive approach to assessment, stream miles in the basin were segmented on the basis of physical features (confluences with tributaries, lakes, and point discharges) that could potentially alter water quality. Lakes were assessed as discrete water bodies. Resources required for an exhaustive approach, in which all stream segments and lakes in the Neponset Basin are assessed and data are collected to evaluate nearly all applicable water-quality standards, were estimated to be about 2,660 personneldays or 12 full-time equivalents (FTEs) for field sample collection and processing and about 4,700 laboratory analyses. The Neponset Basin, areally less than onehalf of the Boston Harbor Watersheds Basin, is small compared to the 27 major basins in Massachusetts, which average about $300 \mathrm{mi}^{2}$ in area (about $400 \mathrm{mi}^{2}$ when basins are combined for MWI teams). Thus, the resource estimates for the Neponset Basin probably represent at best about one-half of the resources needed for an exhaustive assessment of a typical major basin. For statewide implementation with the MWI, in which five major basins are assessed per year, perhaps 10 times the Neponset estimates would be needed, or about 120 FTEs for sample collection and processing and about 47,000 analyses; in all likelihood, more than double the personnel resources would be needed when project planning, field preparation, data management and analysis are included. Thus, resource requirements for a comprehensive assessment of all water bodies using this exhaustive approach are much greater than could be realistically expended.

The monitoring program and results of the 1994 Neponset assessment were reviewed for comparison with the goals and requirements of a comprehensive assessment, such as the exhaustive approach described above. The 1994 study was an in-depth assessment of water resources in the Neponset River Basin, with multiple objectives in addition to that of a basin-wide (though not comprehensive) use-support assessment for the CWA. During that study, about one-half of the total stream miles in the basin were assessed for their designated uses, with a sampling density that was considerably less than that proposed for a systematic, exhaustive assessment of streams and lakes in the basin. All fourth- and fifth-order streams were assessed for most designated uses; the fraction of third-order streams assessed varied from 15 to 85 percent, by use; and less than one-half of second-order streams and less than one-third of first-order streams were assessed for any use. About one- to three-fourths of significant (larger than 5 acres in area) lakes in the basin were assessed for designated uses; lake assessments were based on limited data that resulted in only impairment being assessed for important uses of aquatic life and primary contact recreation.

Analysis of the Neponset Basin hydrography and 1994 study demonstrated that resource-limitation problems will always be posed by the large number of sites needed in order for all the small streams in a basin to be sampled and the need for repeated site visits to assess some uses. Thus, a monitoring program is proposed in which (a) probabilistic monitoring of small streams is combined with the deterministic or targeted monitoring of large streams and (b) deterministic or probabilistic monitoring of lakes may be supplemented with more intensive sampling in lakes of special interest. Small streams, including first-, second-, and third-order streams, are assessed probabilistically for the aquatic life and recreational uses with biomonitoring and bacteria sampling. This approach is proposed to meet the CWA requirement of 100 percent coverage for small streams. Estimates of use support would be provided for all small streams as a group, rather than definitive information for individual streams, and causes or sources of impairments could not be identified. Depending on the resources expended, comprehensive estimates of these uses for small streams could be made on a statewide basis only or for individual basins. For large streams, including fourth-, fifth, and some third-order streams, nearly all designated uses would be assessed, with biomonitoring and sampling for water chemistry, bacteria, sediment, and fish tissue. All large streams in a basin would be assessed using a fixed sampling distance of about 5 miles per sample. This approach is proposed to meet DEP/DWM's need for information on water-quality conditions on specific reaches of these streams. Lakes greater than 10 acres are assessed for aquatic life use and trophic status, with field parameters, macrophytes, Secchi-disk, nutrients, and chlorophyll-a sampling.

The combined probabilistic-deterministic program would provide information to meet CWA requirements and provide data for other information needs of Massachusetts regulatory agencies and MWI teams. It would be implemented on schedule with the 5-year rotating-basin cycle of the MWI, probably in the MWI's research and assessment years. Managementlevel decisions would be needed with respect to program objectives and sampling density for the probabilistic component of the program, about whether estimates of use support are needed for small streams on the statewide scale only or for individual basins 
also. These decisions would affect resource requirements, but with the statewide estimate for small streams only, about 30 FTEs for field sample collection and processing and about 10,500 laboratory analyses would be needed; this assumes that five basins, each of which requires about twice the effort as the Neponset, are assessed per year. Additional time for field preparation and data management could double these requirements to about 60 FTEs, with several additional FTEs needed for program administration, planning, site selection, and obtaining permissions. Although they are much less than the requirements for the exhaustive approach, these resource requirements are substantial. They could be reduced by eliminating or reducing assessment of some designated uses that require intensive sampling, such as the recreational use for small streams or frequent sampling of lakes for trophic status, or by using a probabilistic approach for lakes.

Volunteer monitoring could be used in several ways to enhance the proposed program for Tier I monitoring or to offset the resource requirements for field data collection. Volunteer monitoring, coordinated through the MWI teams, could be used to conduct biomonitoring or collect bacteria samples at additional sites in basins where individual status estimates for small streams are needed; these estimates could be less rigorous if less sophisticated biomonitoring protocols were followed by the volunteer groups than by agency personnel. Volunteer monitoring of additional sites on large streams could be used to increase the number of third-order streams that are deterministically monitored, or to increase the sampling density on mainstem reaches, most likely for aquatic life (water chemistry sampling) or recreational (bacteria sampling) uses. For lakes, volunteer monitoring could be used to increase or maintain the measurement frequency for trophicstatus indicators, to conduct more intensive assessments for some lakes, or to sample lakes of special interest deterministically if a probabilistic approach for lakes generally is taken.

\section{Tier II-Contaminant Loads in Major Rivers}

Tier II is a fixed-station sampling network to determine contaminant loads carried by major rivers. Nineteen sampling sites, in 17 of the 27 major basins in Massachusetts, are proposed. Because continuous streamflow records are needed for accurate loads calculations, the sites are located primarily at or near existing streamflow gages. The proposed sampling sites are: near the mouths of the Merrimack, Aberjona, Charles,
Ipswich, Neponset, and Taunton Rivers, which collectively drain to Boston Harbor, the Gulf of Maine, and Narrangansett Bay; at the mouths of the Millers, Deerfield, Chicopee, and Westfield Rivers, which discharge to the Connecticut River; at the mouths of the Concord and Nashua Rivers, which discharge to the Merrimack River; and at locations on the Quinebaug, French, Blackstone, West Branch Farmington, Housatonic, and Connecticut Rivers near where they enter and(or) leave the State. Sampling at these sites would provide information on contaminant loads from 67 percent of the total land area of the State. The remaining unsampled areas of the State would be primarily coastal areas, which are drained by numerous small streams.

Resource limitations would preclude including all these streams in a loads network. A limited number of sites in small coastal watersheds also could be sampled for a sufficient time (several years) to characterize loads from the watersheds, however, and then discontinued and re-located elsewhere in the coastal area. Loads from some areas, between the coast and the inland limit of tidal influence, will not be determinable without developing site-specific, non-standard methods for flow measurement (through dams, for example), or modelling. Sampling parameters for Tier II monitoring, proposed to provide information on the waterquality issues of concern for receiving waters or specific site locations, include field parameters, bacteria, nutrients, suspended sediment, and possibly metals at some sites. Sampling frequency is determined by the need to characterize adequately the range of hydrologic and seasonal conditions for loads calculations. Thus, about 15 samples per year are proposed, at about monthly intervals but also during high and low flows. The sampling frequency could be enhanced by the use of volunteers or paid observers. Volunteer monitoring would be particularly useful for sediment and sediment-borne contaminants, because frequent sampling is needed to adequately quantify sediment loads. Resource requirements for Tier II of the network were estimated at about 2 FTEs for water-quality sample collection, with additional time needed for field preparation, data analysis and management, and resources for the installation, operation, and maintenance of any new streamflow gages. 


\section{Tier III-Targeted Monitoring Programs}

Targeted programs of Tier III of the proposed network are described primarily in terms of strategies for hot-spot monitoring, that is, monitoring to identify pollution sources. These strategies are investigated using an analysis of the bacteria sampling program of the 1994 Neponset Basin assessment. In that study, data from 41 sites were used to identify leaking sewer lines and failed septic systems, as well as stormwater runoff, as general sources of bacteria contamination in the basin and to confirm that bacteria were a basinwide problem. The bacteria source for a specific impaired reach was identified in only one instance out of 29 impairments, using infrastructure investigation by a town rather than by additional water-quality sampling. An analysis of watershed areas of the sampling sites found little relation between bacteria concentrations and land uses expected to be bacteria sources. These analyses illustrate the difficulties that can arise when a single monitoring design is used to address multiple, sometimes partly conflicting, monitoring objectives. They also demonstrated that effective programs for hot-spot monitoring are based on substantial knowledge of suspected problem areas and on site and contaminant characteristics, information that commonly is compiled by MWI teams and also could be provided to some extent by Tier I of the monitoring program. Monitoring data at all quality levels and the local knowledge of volunteer groups also could be very effective for site selection or source identification. Once known or suspected hot spots are identified, sitespecific sampling programs in terms of sampling parameters and density can be designed. Because these programs are issue-, site-, and basin-specific, resource requirements for an effective program for this component of Tier III of the network cannot be defined in advance.

\section{Tier V-Strategies for Compliance-Based Ambient Monitoring}

The distribution of major National Pollutant Discharge Elimination System (NPDES) sites in Massachusetts was evaluated to determine the usefulness of these sites for the collection of ambient waterquality data. Locations of 155 sites were reviewed. The sites were well distributed geographically among basins, but were located primarily on large rivers, with two-thirds or more on fourth- or higher order streams. Use of these sites for a statewide assessment of stream-water quality, such as needed for Tier I of the monitoring program, would yield estimates of use support that were biased towards large streams. The targeted approach to site selection also would mean that monitoring could not be extrapolated to unsampled streams. Thus, with assumptions of 3 miles of assessed stream per site for first- through third-order streams and 5 miles per site for fourth- and higher order streams, a total of 553 miles, or less than 10 percent of the perennial stream miles in the State, would be assessed by sampling major NPDES sites. NPDES sites might be more suited to sampling for loads or Tier II objectives than for a statewide status assessment. Watersheds of major NPDES sites, where they could be determined, account for about 70 percent of the total land area of Massachusetts. These sites may not be optimally located in terms of the loads objectives, however, and would require review; the isokinetic depthand flow-integrated sampling needed for loads calculations also generally is best implemented by experienced water-quality personnel. Moreover, it might be difficult to adequately design and implement protocols for sample collection, handling, and analysis by multiple private entities to ensure data of sufficient comparability and quality to meet statewide information needs.

\section{Summary}

The water-quality monitoring program described in this report contains several components that would provide information to meet many of the water-quality information needs of the Massachusetts state agencies and others concerned about water resources in the State. The components are complementary in many ways but are not interchangeable, and each component requires a substantial investment of personnel time, laboratory analyses, and other resources. Several components must be developed on site-specific bases, and available resources will place important constraints on all aspects of the program. The water-quality information needs to which components of the proposed program are addressed must be carefully evaluated and prioritized, so that monitoring resources are efficiently and effectively deployed in accordance with the critical tasks of protecting and managing the water resources of Massachusetts. 



\title{
Statewide Water-Quality Network for Massachusetts
}

\author{
By Leslie A. DeSimone, Peter A. Steeves, and Marc J. Zimmerman
}

\section{Abstract}

A water-quality monitoring program is proposed that would provide data to meet multiple information needs of Massachusetts agencies and other users concerned with the condition of the State's water resources. The program was designed by the U.S. Geological Survey and the Massachusetts Department of Environmental Protection, Division of Watershed Management, with input from many organizations involved in water-quality monitoring in the State, and focuses on inland surface waters (streams and lakes). The proposed monitoring program consists of several components, or tiers, which are defined in terms of specific monitoring objectives, and is intended to complement the Massachusetts Watershed Initiative (MWI) basin assessments. Several components were developed using the Neponset River Basin in eastern Massachusetts as a pilot area, or otherwise make use of data from and sampling approaches used in that basin as part of a MWI pilot assessment in 1994. To guide development of the monitoring program, reviews were conducted of general principles of network design, including monitoring objectives and approaches, and of ongoing monitoring activities of Massachusetts State agencies.

Network tiers described in this report are primarily (1) a statewide, basin-based assessment of existing surface-water-quality conditions, and (2) a fixed-station network for determining contaminant loads carried by major rivers. Other components, including (3) targeted programs for hot-spot monitoring and other objectives, and (4) compliance monitoring, also are discussed.
Monitoring programs for the development of Total Maximum Daily Loads for specific water bodies, which would constitute another tier of the network, are being developed separately and are not described in this report. The basin-based assessment of existing conditions is designed to provide information on the status of surface waters with respect to State water-quality standards and designated uses in accordance with the reporting requirements [Section 305(b)] of the Clean Water Act (CWA). Geographic Information System (GIS)-based procedures were developed to inventory streams and lakes in a basin for these purposes. Several monitoring approaches for this tier and their associated resource requirements were investigated. Analysis of the Neponset Basin for this purpose demonstrated that the large number of sites needed in order for all the small streams in a basin to be sampled (about half of stream miles in the basin were headwater or first-order streams) pose substantial resource-based problems for a comprehensive assessment of existing conditions. The many lakes pose similar problems. Thus, a design is presented in which probabilistic monitoring of small streams is combined with deterministic or targeted monitoring of large streams and lakes to meet CWA requirements and to provide data for other information needs of Massachusetts regulatory agencies and MWI teams.

The fixed-station network is designed to permit the determination of contaminant loads carried by the State's major rivers to sensitive inland and coastal receiving waters and across State boundaries. Sampling at 19 proposed sites in 17 of the 27 major basins in Massachusetts would provide information on contaminant loads from 
67 percent of the total land area of the State; unsampled areas are primarily coastal areas drained by many small streams that would be impossible to sample within realistic resource limitations. Strategies for hot-spot monitoring, a targeted monitoring program focused on identifying contaminant sources, are described with reference to an analysis of the bacteria sampling program of the 1994 Neponset Basin assessment. Finally, major discharge sites permitted under the National Pollutant Discharge Elimination System (NPDES) were evaluated as a basis for ambient water-quality monitoring. The discharge sites are well distributed geographically among basins, but are primarily on large rivers (two-thirds or more on fourth- or higher order streams). Thus, NPDES sites alone would provide a biased estimate of existing water-quality conditions, but might be useful for some loads determinations if data of sufficient quality could be collected.

\section{INTRODUCTION}

Public agencies tasked with protecting and managing water resources, the natural environment, and public health have a critical need for information that is gained through water-quality monitoring. Information from water-quality monitoring is needed to assess the existing conditions of water resources, to design preservation, management, and remediation programs, and to evaluate the effectiveness of those programs (Intergovernmental Task Force on Monitoring Water Quality, 1995a). Monitoring also is needed to document compliance with State, Federal, and local regulations and permits. In addition, the results of water-quality monitoring are needed to detect and define trends in water quality, to identify emerging water-quality problems or problem areas, and to increase community awareness of and involvement in water-resource protection.

In Massachusetts, several State and Federal agencies conduct water-quality monitoring for various purposes related to their agencies' missions. In addition, many watershed and lake associations monitor stream- and lake-water quality in many of the State's 27 major river basins. Examples of existing State agency programs include (1) monitoring of benthic macroinvertebrates for aquatic life use-support determinations in five watersheds per year by the Division of Watershed Management (DWM) of the Department of Environmental Protection (DEP), (2) lake-quality monitoring in State-owned lakes by the Office of Water Resources of the Department of Environmental Management (DEM), (3) bacteria and nutrient monitoring in Boston Harbor and its major tributary rivers by the Massachusetts Water Resources Authority (MWRA), and (4) contaminant monitoring in shellfish by the Division of Marine Fisheries (DMF) and fish community monitoring by the Division of Fisheries and Wildlife (DFW) of the Department of Fisheries, Wildlife, and Environmental Law Enforcement (DFWELE). Watershed associations such as the Charles and Neponset River Watershed Associations also monitor ambient stream-water quality by measuring field parameters, bacteria, and nutrients at locations throughout their watersheds; lake associations often maintain long-term records of lakequality parameters such as Secchi-disk depth and aquatic-plant cover.

Existing agency and volunteer monitoring programs, although numerous and well suited to their individual purposes, do not always provide the specific types of data at spatial or temporal scales necessary to meet many of the water-quality information needs in Massachusetts. For example, only 18 percent of total stream miles and 48 percent of lake acres were reported as assessed in the State's 1998 Summary of Water Quality [305(b)] report, and statewide trends cannot be determined from the existing data (Commonwealth of Massachusetts, 1997, 1998). Previous statewide datacollection programs have been biased towards larger rivers, known problem areas, and point pollution sources; in this way, the programs have provided limited spatial coverage and have not adequately depicted water-quality conditions throughout the State. Many watershed associations and other volunteer groups collect monitoring data, but their activity is unevenly distributed statewide and often is limited to small areas and to a small number of water-quality parameters. Finally, the lack of mechanisms to link monitoring results, such as common systems for site location or data storage, documentation, or reporting, makes it difficult to coordinate existing programs or to aggregate their results into larger-scale assessments.

Consistent and comprehensive water-quality data at the state- and basin-wide scales are needed (1) to meet the State's assessment and reporting requirements under the Federal Clean Water Act (CWA), (2) to 
support the assessment and remedial activities of the Executive Office of Environmental Affairs (EOEA) Massachusetts Watershed Initiative (MWI) teams and to allow for comparison of water-quality conditions among major basins, and (3) to evaluate the effectiveness of large-scale pollution prevention and remediation programs. Scientifically valid and defensible sitespecific data also are needed by statewide programs to identify impaired water bodies and to support the development of Total Maximum Daily Loads (TMDLs) for impaired waters. Finally, information is needed on pollutant loads carried by major rivers to sensitive receiving waters and across State boundaries and on how these loads may be changing with time. To address these multiple information needs, the DEP/DWM worked with the U.S. Geological Survey (USGS) to design a comprehensive statewide waterquality monitoring strategy for Massachusetts. The $\mathrm{DEP} / \mathrm{DWM}$ is the state agency tasked with monitoring and regulatory activities regarding water quality in the State's major basins (Massachusetts Department of Environmental Protection, 1997).

As an initial step in developing a statewide monitoring strategy, the USGS and DEP/DWM circulated a draft plan that outlined goals, objectives, and preliminary approaches of the proposed program among State and Federal agencies and other organizations involved in monitoring in Massachusetts. This plan contained eight general objectives for the network, which were to provide information for (1) definition of existing water resource conditions, (2) detection and definition of trends in concentrations, loads, and habitat, (3) calibration and validation of models, (4) evaluation of management strategies and program effectiveness, (5) detection of emerging problems, (6) design of abatement, control, and management strategies, (7) regulatory needs, including CWA, TMDLs, and enforcement, and (8) watershed teams. The plan's scope included network design and data collection along with data management and reporting; its approach included five separate components, including statewide fixed-station sampling, basin-wide rotatingsite sampling in conjunction with MWI teams, sitespecific and issue-specific sampling, and volunteer sampling. This draft plan was subsequently revised to focus the monitoring program on the objectives defined by the CWA and other statewide water-quality information needs, and to limit its scope primarily to network design. The Neponset River Basin in eastern Massachusetts was chosen as a pilot area for developing the basin-based components of the network design.

This report describes several proposed components of a comprehensive statewide water-quality monitoring program for Massachusetts. These components were developed by the USGS and DEP/DWM from 1998 to 2000. A basin-based monitoring design, developed for the Neponset Basin, could be implemented across the State to meet requirements of the Federal CWA and other large-scale water-quality information needs. A fixed-station network could be used to determine loads of contaminants delivered by the State's major rivers. A review of monitoring strategies for identifying pollution sources, or "hot-spot monitoring", which is an objective of the MWI teams, incorporates further analysis of data from the Neponset basin. Finally, an analysis is presented of waterquality monitoring network that would make use of compliance monitoring conducted under the National Pollutant Discharge Elimination System (NPDES) requirements.

In several sections of this report, estimates of the resources required are presented, primarily in terms of personnel and laboratory analyses, to implement the monitoring programs as described. Aspects of the monitoring program that could be enhanced by the use of volunteer monitors also are identified; these aspects generally are consistent with recommendations of a recent report to EOEA on volunteer monitoring (Dates and others, 2000). It should be noted that the agency personnel and laboratory estimates are based on assumptions about the personnel requirements of specific sampling tasks. The resource estimates are presented for comparison of monitoring program components and alternatives, and to describe the magnitude of the proposed effort. They are not intended to be used as rigorous, quantitative evaluations. Finally, additional resources for planning, data management, data analysis, and coordination with volunteer groups, if used, would be needed to implement fully the proposed monitoring programs; estimates of these additional resources are inherently more uncertain than personnel and laboratory estimates.

The monitoring strategies described in this report are limited to inland surface waters for several reasons. Although within the scope of the Clean Water Act (which generally is within DEP/DWM's mandate), State agencies other than DEP/DWM have responsibility for coastal monitoring in Massachusetts. 
Monitoring of drinking-water quality is conducted under an existing, well-defined program within DEP with separate Federal and State regulatory requirements. Ambient ground-water monitoring, while an important part of a comprehensive water-resource monitoring program, is not currently planned in the State. Information is provided on these and other monitoring programs of State agencies, however, to facilitate future investigation of mechanisms for integrating these efforts into a comprehensive statewide strategy for water-quality monitoring in Massachusetts.

\section{DESIGN CONSIDERATIONS FOR A STATEWIDE MONITORING NETWORK}

\section{Monitoring Objectives}

The first step in the design of any water-quality monitoring program is to define the objectives of the monitoring activity. Monitoring objectives also may be represented as information needs, the fulfillment of which allows water-quality managers and others to make informed decisions about regulations, actions, or programs. General objectives of water-quality monitoring programs commonly are stated to include determining current water-quality conditions, detecting trends, identifying problems, and collecting data for model studies (Ward and others, 1990). However, because of the large inherent variability, both spatial and temporal, in water-quality conditions and because of the wide variety of parameters that can be measured as indicators of quality, monitoring objectives usually must be much more specifically defined than the commonly stated general objectives in order to design effective monitoring programs. Collecting data in advance of or without an identified information need, while appropriate for a fundamental and relatively simple parameter such as water quantity (that is, streamflow), is problematic for a highly variable and multifaceted characteristic such as water quality (R.P. Hooper, U.S. Geological Survey, written commun., 1996).

Specific objectives of a monitoring program developed to meet the information needs of the DEP/DWM in Massachusetts can be derived from the regulatory mandates and statutory interests of that agency ${ }^{1}$. As the state agency responsible for monitoring and regulatory activities regarding inland water quality, the DEP/DWM, with the U.S. Environmental Protection Agency, is responsible for implementing the Federal CWA in Massachusetts. For example, section 305(b) of the CWA requires that each State develop a water-quality monitoring program and periodically report the status of its water quality (U.S. Environmental Protection Agency, 1997a). This assessment is expected to be comprehensive, in that all surface-water bodies (streams, lakes, and coastal waters), as well as ground water, are included. Water-quality status for this purpose is described in terms of the waters' suitability for various uses, such as drinking water, fishing, swimming, and aquatic life; these uses are formally defined as "designated uses" in State and Federal regulations. Section 303(d) of the CWA requires that waters that do not meet applicable water-quality standards after implementation of effluent-discharge controls be identified, and TMDLs be determined for these waters (U.S. Environmental Protection Agency, 1997a). DEP/DWM also has responsibility for supporting MWI teams by conducting water-quality and biomonitoring surveys in the second year of the MWI's 5-year assessment and remedial cycles. DEP/DWM and MWI teams need this and other information to assess watershed water-quality conditions ("health") at the river basin scale, to identify impaired waters and pollution sources ("hot spots") at the reconnaissance level, and to determine the effectiveness of specific management actions (best management practices, or BMPs) in their basins. DEP/DWM and other state agencies also have an interest in determining the loads of and time-trends in pollutants delivered by large rivers to sensitive receiving waters, such as Boston Harbor, and across State boundaries. Finally, DEP/DWM, in conjunction with USEPA, is responsible for regulating and determining compliance of surface-water dischargers with NPDES permits.

These information needs, defined by CWA mandates, MWI requirements, and the other regulatory interests described above, define a set of objectives on which to build a comprehensive and adequate statewide water-quality monitoring program. A program is

\footnotetext{
${ }^{1}$ A comprehensive monitoring strategy for the State would include objectives derived from the mandates and interests of all State agencies and other organizations; although outside of the scope of the current effort, the survey information provided on monitoring programs of other agencies, described in a subsequent section of the report, provides useful background information for this purpose.
} 
proposed that consists of several components or "tiers," that reflect the different spatial and temporal scales of the identified water-quality information needs and the different purposes, for example, regulatory or reconnaissance, for which the data are used. Tier I consists of monitoring for objectives defined by the 305(b) assessment, that is, the status of the State's waters relative to applicable water-quality standards. Monitoring for this objective would be implemented on a 5-year, rotatingbasin basis, reflecting the State's strong commitment to the watershed approach. Tier II consists of monitoring for pollutant loads and trends at the mouths of major rivers. Tier III consists of sampling that is targeted spatially or by issue, and includes data collection for 303(d) listing of impaired waters, causes and sources of impairments for 303(d) and 305(b) purposes, "hotspot" monitoring, and other site-specific investigations. Tier IV consists of monitoring for TMDL development for specific water bodies.

The monitoring program described in this report is most fully developed for Tiers I and II, which are statewide in scale. Monitoring designs for Tiers III and IV will vary significantly based on site characteristics and the purpose of the investigation. Thus, designs for these tiers generally are not suited for definitive development at the statewide scale. Strategies for TMDL development and monitoring in Massachusetts are being developed separately (D.R. Dunn, Massachusetts
Department of Environmental Protection, written commun., 1999), and are not discussed in this report. Monitoring for compliance with NPDES and other permits also is highly variable and site specific, and is closely tied to purposes defined by individual permits. Compliance monitoring historically has been managed separately from most ambient monitoring programs (Intergovernmental Task Force on Monitoring Water Quality, 1995a, b). The MWI approach, however, provides a link between water-resource assessment and compliance monitoring at the basin scale, and compliance monitoring is a possible fifth tier in the proposed statewide monitoring program. An investigation of potential links between ambient and compliance monitoring at the statewide scale is provided in this report through an analysis of the spatial distribution of NPDES dischargers in Massachusetts.

\section{Monitoring Approaches}

Monitoring approaches comprise the specifics of how water-quality measurements will be made to provide the information needed to meet monitoring objectives. Monitoring activities/approaches can be described in terms of five categories that also can be considered as types of monitoring (fig. 1).

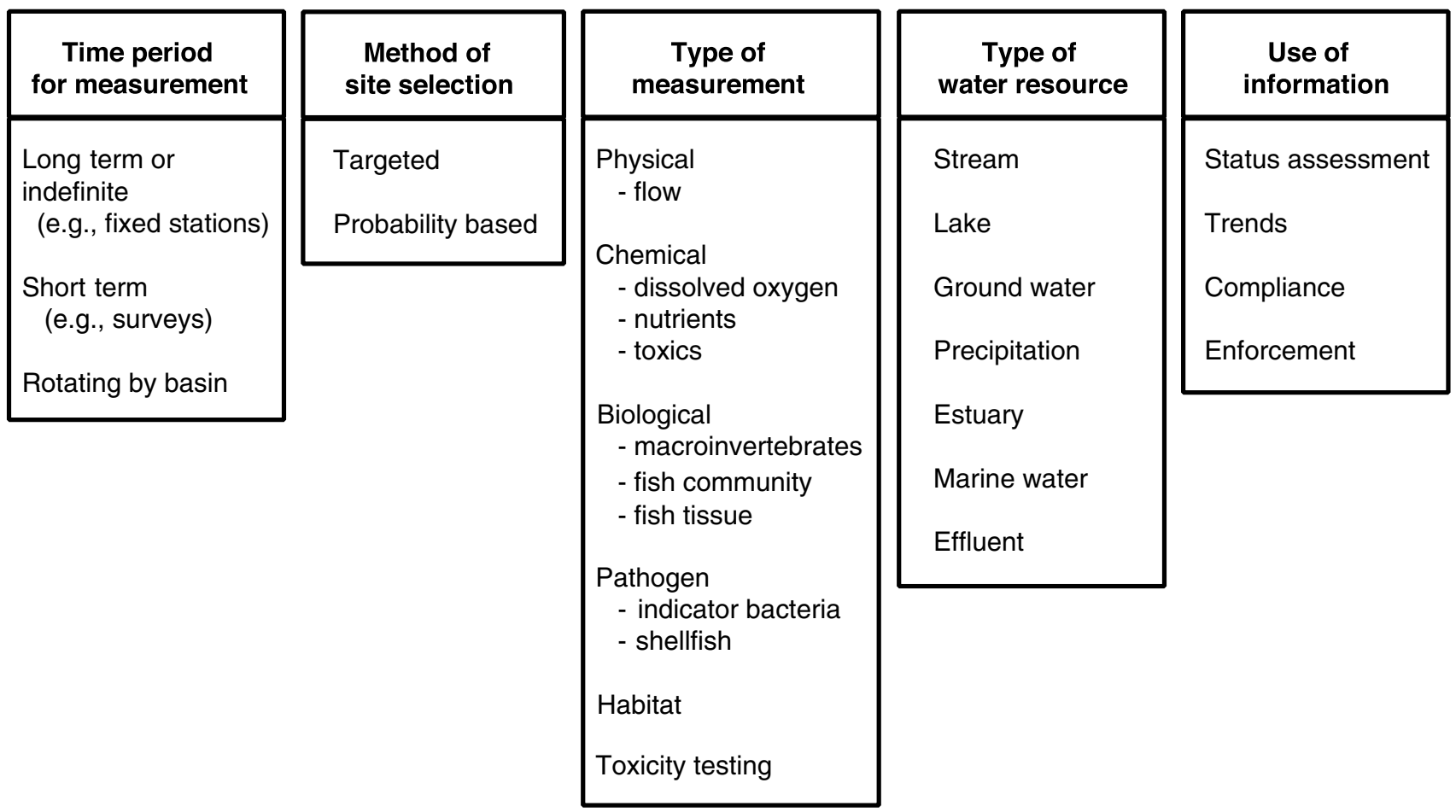

Figure 1. Types of monitoring (modified from Ward and others, 1990, p. 10-12, and U.S. Environmental Protection Agency, 1997b, Appendix 1). 
A specific monitoring approach contains elements from each of these monitoring-type categories, which are chosen to fit the water-quality questions posed by the monitoring objective. No single monitoring approach or type of monitoring can provide the data needed to address all water-quality information needs.

Monitoring in which the same sites are repeatedly sampled, at regular time intervals, over an indefinite or long period of time, commonly is called fixedstation monitoring. This type of monitoring formed the basis of traditional water-quality networks, including the first phase of the U.S. Geological Survey's National Stream Quality Accounting Network (NASQAN; R.P. Hooper, written commun., 1996; Hooper and others, 1997). Fixed-station sampling is useful for long-term monitoring, for detection of trends, for assessment of larger streams, and for monitoring critical reaches of streams with regulated or permitted discharges. Fixedstation monitoring, with the collection of flow data, is essential for the calculation of contaminant loads by rivers, which may be needed at strategic locations such as State borders. However, fixed-station monitoring programs must be carefully designed with intended use of the data collected in mind. For example, if contaminant loads are needed, then the sampling schedule must be constructed such that the range of hydrologic conditions (high and low flows or seasonal variations) during which the specific contaminants of interest are transported are sampled; or, sampling must be frequent enough so that the relevant range of conditions can be subsequently determined. The number of samples collected within the time period of interest also must be adequate for statistically valid calculations. Special consideration must be given to contaminants that are associated with wet-weather flow, because sampling at periodic, fixed intervals may inadequately characterize loads and water-quality conditions that result from contaminant inputs that change rapidly during rainfallrunoff events. Finally, a trade-off exists between design requirements for the detection and interpretation of trends and for determining loads. Stations selected for loads determinations are likely to be located at the mouths of relatively large basins; however, large basins commonly are heterogeneous in land use and other factors affecting stream-water quality, making it difficult to relate trends detected at these sampling stations to specific causes or changes within the basins (Smith and others, 1987). A lack of high-quality, time-series data on factors affecting water quality also makes it difficult to identify the causes of trends that may be detected.

Fixed-station monitoring generally is not the best single approach for a comprehensive assessment of water resources at the state-wide or basin scale, for several reasons. This type of monitoring requires a long-term commitment of a large amount of resources, which generally will severely limit the number of stations that can be operated. With limited numbers of sampling stations, water-quality conditions must be extrapolated for long distances up- and downstream from the sampling site to obtain the spatial coverage necessary for state- or basin-wide assessments. Such extrapolation often is not valid, because many waterquality parameters (for example, dissolved oxygen, bacteria, and contaminants associated with sediments) are not conservative - that is, they are subject to attenuation or transformation and can change rapidly in concentration downstream. Moreover, there often are multiple or even continuous inputs of contaminants along a stream reach that can change water-quality conditions and make an extrapolation invalid. In addition, the resource limitations of fixed-station sampling often results in selecting sites on relatively high-order (that is, larger) streams. A network of sites on large streams will not provide information on water quality in specific low-order (that is, smaller) tributaries, but will only describe a cumulative water quality. For example, a low-order stream may have serious violations of water-quality criteria, but dilution of contaminants in the larger stream may mask these problems.

Another approach, short-term monitoring, includes special studies that generally are directed towards specific water-quality problems and synoptic surveys that provide "snapshots" of water-quality conditions over a wide area. The spatial coverage provided by synoptic surveys, in which many sites are sampled, makes this type of monitoring useful for areal assessments of existing conditions and hot-spot monitoring. Climatic, seasonal, and other temporal variability in water quality conditions are important considerations for short-term monitoring programs. Short-term temporal variability in many water-quality constituents, such as dissolved oxygen and indicator bacteria, may mean that sites will need to be sampled repeatedly, even in synoptic surveys, to characterize the water-quality conditions of interest, or that the sampling period must be carefully chosen, perhaps to 
represent "worst case" conditions. Multi-year climatic variability may make it difficult to compare short-term monitoring results to historical data or data collected in other basins during different assessment years. Changes with time resulting from management practices or changing land uses also may be difficult to identify using short-term monitoring programs.

Rotating-basin programs, in which intensive short-term surveys are conducted periodically in a watershed, may both provide wide spatial coverage and allow for the identification of changes in water-quality conditions with time. However, consistency of monitoring approaches, data-collection procedures, and laboratory analytical procedures are needed so that the results of sequential basin assessments are comparable. Climatic variability also may limit data comparability.

Methods of site selection define a category of monitoring types that also places important constraints on the uses of data collected from monitoring networks (fig. 1). A common method used in monitoring programs is the targeted approach whereby sites are selected for multiple, site-specific reasons. For example, in a recent USGS/DEP/EOEA monitoring program for streamflow and quality in an Eastern Massachusetts watershed, 45 possible sampling sites, of which 10 were used, were proposed for the following reasons: (1) to determine the effects of likely problem areas or activities, such as septic tanks, stormwater, highway construction, and waste management; (2) to determine baseline conditions upstream of major known pollution sources; (3) to determine conditions at boundaries of subwatersheds; (4) to document conditions prior to remedial actions; (5) to determine conditions for fish passage and fishery-stream habitat; (6) to determine conditions in streams flowing to sensitive areas such as water supplies and State-designated Areas of Critical Environmental Concern; (7) to investigate reports of impaired quality; and (8) to confirm 303(d) listing of impaired waters. Data collected from programs such as this one can fill important information needs, such as identifying impaired waters and sources, identifying conditions and trends at specific sites, evaluating improvements due to specific management actions in a watershed, and, with biomonitoring, provide information on the biological response to water-quality stressors. However, results of such targeted sampling programs cannot easily be extended to unsampled sites, and so cannot provide comprehensive areal assessments of conditions throughout a basin or state. Without defensible information on the extent and severity of a water-quality problem at the statewide scale, it may be difficult to justify the expenditure of resources for its large-scale remediation or control (U.S. Environmental Protection Agency, 1997b).

Probability-based approaches are alternatives to targeted sampling programs capable of providing comprehensive assessments of water-quality conditions throughout an area. In these approaches, representative sampling sites are chosen and conditions in the entire population of the water resource are inferred from monitoring results for these sites. In a probabilitybased approach, sites are selected randomly from the total population of a water-resource type in an area (for example, from all streams or lakes in a watershed or state). Because the sites are selected randomly, monitoring results can be extrapolated to estimate conditions in the total population with a known statistical confidence (U.S. Environmental Protection Agency, 1997b). In a stratified-random approach, the population of water bodies is divided into categories, for example, by size or geographic area, and sites are randomly selected from within these categories. This approach could provide better estimates of conditions in each category, because the variability within the categories is less than in the entire population; it also allows for sampling procedures to be varied among categories.

The probability-based approach is advantageous in that it could provide an unbiased, comprehensive assessment of the status of a State's water bodies required by section 305(b) of the CWA. This approach also could provide more information on the State's small streams, and on water bodies generally that are not expected to be affected by large pollution sources. However, a probability-based approach cannot provide information on specific sites (unless they happen to be included in the random selection) for documenting impairments, for identifying new problem areas, for detecting trends or evaluating improvements (U.S. Environmental Protection Agency, 1997b). Monitoring resource limitations may result in a small number of selected sampling sites, such that the confidence bands around the statewide estimates are large. Moreover, because an estimate of the water-quality status of the entire resource by itself cannot provide information on the sources or causes of impairment, the information provided by a probability-based approach may be of limited use to managers in their efforts to improve water quality. In addition, logistical difficulties, in terms of accessing the randomly selected sites, may 
arise that unexpectedly increase the personnel costs of the program when probability-based approaches are implemented.

Another alternative for a comprehensive assessment of a water resource is a deterministic or exhaustive monitoring approach, in which all water bodies in an area are sampled or otherwise surveyed. This is a kind of targeted approach, but with no discrimination among potential sampling sites. In most cases, this approach will be severely affected by resource limitations. For example, sampling all 8,229 stream miles in Massachusetts (Commonwealth of Massachusetts, 1998), using USEPA recommended distances of 5 to 10 mi per site for wadeable streams and $25 \mathrm{mi}$ per site for larger streams (U.S. Environmental Protection Agency, 1997a), and an estimated ratio of 6:1 for small to large streams (where small streams are first, second, and third order and large streams are fourth and fifth order; this estimate is derived from the Neponset Basin analysis, described below), would require 754 to 1,560 sampling sites at a minimum. These values are likely to be underestimates of the number of sites required to characterize the spatial variability in water-quality conditions in Massachusetts streams, given the heterogeneous land uses, relatively short length of streams between tributaries, and frequency of point sources and dams in the State. These factors are potentially significant influences on water quality and decrease the length of stream of which a sampling site could be representative. Similarly, there are several thousand lakes in Massachusetts (Robert Hartzel, Massachusetts Department of Environmental Management, written commun., 1993), all of which would need to be sampled in an exhaustive approach. Moreover, these stream and lakes sites would need to be sampled repeatedly for some water-quality conditions. One potentially feasible approach for an exhaustive monitoring program within realistic resource limitations might be to use remote-sensing techniques; an example would be the use of remote-sensing data to provide reconnaissance-level information on the trophic state of lakes (Waldron and others, 2001). However, assessments conducted through such methods would be considered less rigorous than those based on direct sampling.

Monitoring also may be defined by the waterquality indicators or parameters measured (fig. 1). In physical and chemical monitoring, parameters such as flow, temperature, $\mathrm{pH}$, dissolved oxygen, turbidity, and chemical concentrations in the water column and sediment are measured. Biological monitoring (biomonitoring) can include the identification and enumeration of macroinvertebrates, fish communities, or macrophytes (aquatic plants) and measurements of fish-tissue-contaminant, algae, or chlorophyll-a concentrations. Physical and chemical parameters also are considered exposure indicators, in that they depict the level of exposure for aquatic life (or humans) to stressors, whereas biomonitoring indicators, or response indicators, depict the response of the biological community to the physical and chemical stressors (C.O. Yoder, Ohio Environmental Protection Agency, written commun., 1997). Advantages to physical and chemical monitoring are that the measurements or samples are relatively simple to make or collect, and the results generally are unambiguous and quantitative. On the other hand, these parameters are spatially and temporally variable, potentially numerous, and can be costly to analyze. Routinely analyzing for all potential stressors in a monitoring network, especially when organic compounds and metals are included, can be prohibitively expensive. Biomonitoring indicators are advantageous in that they directly assess biological integrity and may be more valid measures of impairment for aquatic life uses than the status of waters relative to numerical water-quality standards (C.O. Yoder, written commun., 1997; U.S. Environmental Protection Agency, 1999). Biomonitoring indicators such as macroinvertebrate assessments also integrate the effects of stressors over time, thereby more accurately representing water-quality conditions that are highly variable than repeated point measurements of physical or chemical indicators; they also can reflect the effects of unknown stressors. However, although biomonitoring indicators may more readily detect impairments, they generally cannot provide information to indicate the causes or sources of the impairments. Moreover, biomonitoring approaches are not appropriate for assessing the status of waters for uses involving human health. Finally, different specialized skills may be needed to conduct biomonitoring assessments than those needed to sample for physical and chemical parameters.

Other categories or types of monitoring are based on the type of water resource being monitored and the uses of the monitoring results (fig. 1). Monitoring approaches for streams, lakes, ground-water, and other water-resource types must suit the temporal and spatial variability that results from the unique hydrologic regime of the water resource. Logistical aspects 
of sampling the various water-resource types also must be considered. For example, daily or more frequent sampling may be needed to characterize water-quality in some streams, especially during storm events, whereas weekly sampling may be adequate for lakes, and monthly or less frequent sampling would be sufficient to characterize ground-water quality. The intended use of the information also affects the dataquality objectives of the program, as well as other aspects of the monitoring approach design, including the frequency, location, and types of measurements collected.

This review of monitoring approaches reemphasizes the importance of a clear definition of goals and objectives before monitoring programs can be designed. Multiple approaches may be needed in a monitoring program to meet conflicting requirements of the identified water-quality information needs. Finally, knowledge of the hydrologic and water-quality system, including the physical, chemical, and biological processes affecting the sources, transport, and attenuation of contaminants of concern, also is essential in developing the monitoring approaches that will meet the program's objectives.

\section{Ongoing Monitoring Activities by State Agencies in Massachusetts}

To determine the extent of water-quality monitoring activities in the Commonwealth of Massachusetts, the USGS, on two occasions, contacted State agencies and their constituent divisions, offices, bureaus, and programs. In 1998, a written questionnaire was distributed and, in 2000, telephone calls were made to supplement and update the responses to the 1998 questionnaire. Massachusetts agencies contacted included the DEP, DEM, DFWELE, Massachusetts Coastal Zone Management (MCZM), MWRA, Metropolitan District Commission (MDC), Department of Public Health, Massachusetts Highway Department (MHD), Cape Cod Commission, and Massachusetts Waterwatch Partnership. This section reports on ongoing water-quality-monitoring activities in the State as determined from these contacts (table 1) and briefly discusses how these activities might be used in a comprehensive statewide water-quality monitoring strategy.
The DEP/DWM is responsible for coordination of water-quality and quantity monitoring and regulation in the State's major watersheds. Through the MWI, the DEP now assesses water quality on a rotating basis in the 27 major watershed units across Massachusetts on a 5-year cycle, with approximately 5 watershed-unit water-quality assessments taking place each year. The assessments are multi-purpose in nature, with physical, chemical and biological waterquality being evaluated primarily to determine if the water bodies or portions of them meet water-quality standards and their designated uses. Typical monitoring program elements currently include lake sampling for TMDL development, fish-toxics monitoring, benthic macroinvertebrate measurements, and siteor issue-specific water-quality sampling especially for CWA purposes (A.S. Johnson, Massachusetts Department of Environmental Protection, Division of Watershed Management, written commun., 1999). Much of the monitoring occurs in MWI basins that are in the research year (Year 2) of the 5-year cycle. Fixedsite ambient monitoring is not conducted statewide, although a pilot program is underway in the Central Region (A.S. Johnson, Massachusetts Department of Environmental Protection, Division of Watershed Management, written commun., 1999).

Several agencies in addition to the DEP/DWM, including MWRA, MDC, MHD or their subdivisions, and DFWELE, support routine, environmental waterquality monitoring (table 1). Others monitor for compliance with specific regulations, such as monitoring by DEP's Drinking Water Program for public-water supply compliance with drinking-water-quality regulations. Some agencies support water-quality studies through the administration of special programs and grants for relatively short-term studies; these agencies include the MCZM and the Lakes and Ponds Program of the DEM. The MCZM's Marine Monitoring and Research Program assesses wetlands and studies the effects of contaminated sediment, for example. The DEM Lakes and Ponds Program performs studies of water-quality problems related to occasional low flushing rates in lakes in some state parks.

The MDC through its Watershed Management Division collects a great deal of environmental data in its extensive fixed-site network in the Quabbin Reservoir, Ware River, and Wachusett Reservoir watersheds. This network monitors drinking-water sources used by much of the metropolitan Boston area. Samples are collected from many tributary streams and the reservoirs at frequencies that vary depending on the water-quality constituent monitored. 
Table 1. Ongoing water-quality monitoring in Massachusetts by State agencies and programs

[Agencies included in this table were contacted during January through March 2000; MWI, Massachusetts Watershed Initiative; --, not applicable]

\begin{tabular}{|c|c|c|c|c|c|c|}
\hline Agency & Program & $\begin{array}{c}\text { Description } \\
\text { and focus of } \\
\text { monitoring program }\end{array}$ & $\begin{array}{l}\text { Sampling } \\
\text { parameters }\end{array}$ & $\begin{array}{c}\text { Type of } \\
\text { sampling site }\end{array}$ & $\begin{array}{l}\text { Duration of } \\
\text { sampling }\end{array}$ & $\begin{array}{l}\text { Geographic area } \\
\text { of activity }\end{array}$ \\
\hline Cape Cod Commission & Water Resources Office & $\begin{array}{l}\text { Site-specific assessment } \\
\text { projects }\end{array}$ & Vary by project & Vary by project & Short term & Cape Cod \\
\hline \multirow[t]{3}{*}{ Coastal Zone Management } & $\begin{array}{l}\text { Coastal Water Quality/ } \\
\text { Coastal Nonpoint } \\
\text { Pollution Control }\end{array}$ & -- & -- & -- & -- & -- \\
\hline & $\begin{array}{l}\text { Coastal Water Quality/ } \\
\text { Massachusetts Bays }\end{array}$ & Wetlands health & $\begin{array}{l}\text { Dissolved oxygen, } \mathrm{pH}, \\
\text { nutrients, salinity, } \\
\text { macroinvertebrates, } \\
\text { vegetation, birds }\end{array}$ & Fixed & Short term & Coastal areas \\
\hline & $\begin{array}{l}\text { Marine Monitoring and } \\
\text { Research }\end{array}$ & $\begin{array}{l}\text { Wetlands assessments; } \\
\text { contaminated sediments }\end{array}$ & $\begin{array}{l}\text { Water chemistry, } \\
\text { macroinvertebrates, } \\
\text { vegetation, birds }\end{array}$ & Variable & Short term & Coastal areas \\
\hline \multirow[t]{5}{*}{$\begin{array}{l}\text { Department of Environmental } \\
\text { Management }\end{array}$} & Forests and Parks & $\begin{array}{l}\text { No ongoing monitoring } \\
\text { program }\end{array}$ & -- & -- & -- & -- \\
\hline & $\begin{array}{l}\text { Natural Resources /Areas } \\
\text { of Critical } \\
\text { Environmental Concern }\end{array}$ & $\begin{array}{l}\text { No ongoing monitoring } \\
\text { program }\end{array}$ & -- & -- & -- & -- \\
\hline & $\begin{array}{l}\text { Water Resources / Data } \\
\text { Collection and Analysis }\end{array}$ & $\begin{array}{l}\text { Cooperative programs with } \\
\text { USGS }\end{array}$ & Vary by program & $\begin{array}{l}\text { Fixed and } \\
\text { variable }\end{array}$ & $\begin{array}{l}\text { Short and } \\
\text { long term }\end{array}$ & $\begin{array}{l}\text { Varies by } \\
\text { program }\end{array}$ \\
\hline & $\begin{array}{l}\text { Water Resources / Lakes } \\
\text { and Ponds }\end{array}$ & $\begin{array}{l}\text { Lakes and ponds in some } \\
\text { State parks }\end{array}$ & Vary by issue & Variable & Short term & Statewide \\
\hline & Engineering / Waterways & $\begin{array}{l}\text { No ongoing monitoring } \\
\text { program }\end{array}$ & -- & -- & -- & -- \\
\hline \multirow[t]{2}{*}{$\begin{array}{l}\text { Department of Environmental } \\
\text { Protection }\end{array}$} & $\begin{array}{l}\text { Resource Protection / } \\
\text { Drinking Water }\end{array}$ & $\begin{array}{l}\text { Compliance of public-water } \\
\text { suppliers with drinking- } \\
\text { water regulations }\end{array}$ & $\begin{array}{r}\text { Drinking-water } \\
\text { contaminants }\end{array}$ & Fixed & Long term & Statewide \\
\hline & $\begin{array}{l}\text { Resource Protection / } \\
\text { Watershed Management }\end{array}$ & $\begin{array}{l}\text { Clean Water Act monitoring } \\
\text { and assessment; } \\
\text { Massachusetts Watershed } \\
\text { Initiative (MWI) } \\
\text { monitoring }\end{array}$ & $\begin{array}{l}\text { Water chemistry; benthic } \\
\text { macroinvertebrates; } \\
\text { lake vegetation; fish } \\
\text { toxics; others }\end{array}$ & Variable & Short term & $\begin{array}{l}\text { Statewide, but } \\
\text { focused in } \\
\text { MWI Year } 2 \\
\text { basins }\end{array}$ \\
\hline
\end{tabular}


Table 1. Ongoing water-quality monitoring in Massachusetts by State agencies and programs-Continued

\begin{tabular}{|c|c|c|c|c|c|c|}
\hline Agency & Program & $\begin{array}{c}\text { Description } \\
\text { and focus of } \\
\text { monitoring program }\end{array}$ & $\begin{array}{l}\text { Sampling } \\
\text { parameters }\end{array}$ & $\begin{array}{c}\text { Type of } \\
\text { sampling site }\end{array}$ & $\begin{array}{l}\text { Duration of } \\
\text { sampling }\end{array}$ & $\begin{array}{c}\text { Geographic area } \\
\text { of activity }\end{array}$ \\
\hline & $\begin{array}{l}\text { Resource Protection / } \\
\text { Wetlands and } \\
\text { Waterways }\end{array}$ & $\begin{array}{l}\text { No ongoing monitoring } \\
\text { program }\end{array}$ & -- & -- & -- & -- \\
\hline \multirow[t]{2}{*}{$\begin{array}{l}\text { Department of Fisheries, } \\
\text { Wildlife, and Environmental } \\
\text { Law Enforcement }\end{array}$} & Fisheries and Wildlife & $\begin{array}{l}\text { Fish community surveys in } \\
\text { MWI watersheds; special } \\
\text { studies related to game } \\
\text { fish population }\end{array}$ & Fish community & -- & -- & -- \\
\hline & Marine Fisheries & Fish and shellfish health & $\begin{array}{l}\text { Dissolved oxygen, } \\
\text { temperature, bacteria }\end{array}$ & Fixed & Long term & Coastal areas \\
\hline Department of Public Health & $\begin{array}{l}\text { Environmental Health } \\
\text { Assessment }\end{array}$ & $\begin{array}{l}\text { No ongoing monitoring } \\
\text { program }\end{array}$ & -- & -- & -- & -- \\
\hline $\begin{array}{l}\text { Massachusetts Highway } \\
\text { Department }\end{array}$ & Research and Materials & $\begin{array}{l}\text { Highway runoff and public- } \\
\text { water supplies }\end{array}$ & Road-salt constituents & Fixed & Variable & Statewide \\
\hline \multirow[t]{2}{*}{$\begin{array}{l}\text { Metropolitan District } \\
\text { Commission }\end{array}$} & $\begin{array}{l}\text { Watershed Management / } \\
\text { cooperatively with } \\
\text { Massachusetts Water } \\
\text { Resources Authority }\end{array}$ & Drinking-water protection & $\begin{array}{l}\text { Nutrients, alkalinity, } \\
\text { hardness, bacteria and } \\
\text { other pathogens, and } \\
\text { macroinvertebrates }\end{array}$ & Fixed & Long term & $\begin{array}{l}\text { Quabbin } \\
\text { Reservoir, } \\
\text { Ware River, } \\
\text { and Wachusett } \\
\text { Reservoir } \\
\text { watersheds }\end{array}$ \\
\hline & Watershed Management & Public-beach monitoring & Bacteria & Fixed & $\begin{array}{l}\text { Long term, } \\
\text { summer }\end{array}$ & Public beaches \\
\hline $\begin{array}{l}\text { Massachusetts Water } \\
\text { Resources Authority }\end{array}$ & & $\begin{array}{l}\text { Water quality in Boston } \\
\text { Harbor and tributaries }\end{array}$ & $\begin{array}{l}\text { Sewage contaminants } \\
\text { (nutrients, bacteria, } \\
\text { others) }\end{array}$ & Fixed & Long term & $\begin{array}{l}\text { Boston Harbor } \\
\text { and } \\
\text { tributaries; } \\
\text { beaches }\end{array}$ \\
\hline
\end{tabular}


Sampling frequency ranges from daily for Quabbin Reservoir (although samples are sometimes collected twice daily at the outlet to the aqueduct), to biweekly at tributary sites. Sampling parameters are primarily indicator bacteria and nutrients (nitrogen and phosphorus species). Monthly reservoir depth profiles for temperature, $\mathrm{pH}$, dissolved oxygen, and specific conductance also are made in Quabbin Reservoir from April through November. In the Wachusett watershed, indicator bacteria samples are collected generally daily in the reservoir and weekly in tributaries; nutrients are sampled weekly in tributaries; and reservoir profiles are conducted monthly. Field parameters of temperature, dissolved oxygen, $\mathrm{pH}$, and specific conductance are measured at the time of sample collection. Sampling also is conducted for Giardia, Cryptosporidium, phytoplankton in Quabbin and Wachusett watersheds and, on occasion in Quabbin, includes a number of other water-quality constituents, such as iron, color, turbidity, and total suspended solids. In addition to the waterchemistry and bacteria monitoring, an MDC biomonitoring program conducts macroinvertebrate sampling at about 12 to 24 fixed sites in tributary streams. The macroinvertebrate data are used as integrated measures of stream quality and changes in quality over time.

The MWRA monitors water quality in Boston Harbor and its tributaries. In addition, MDC's Watershed Management Division, working for the MWRA, monitors for potential beach contamination by bacteria in summer that may cause the beaches to be closed. Monitored areas include the Charles, Neponset, and Mystic Rivers, Dorchester Bay, and the Inner Harbor. Water-quality conditions in these areas are determined by regular sampling and measurements of algae, suspended solids, turbidity, dissolved oxygen, and nutrients. The health of fish, shellfish, and other harbor animal communities also is routinely monitored.

The stream water-quality data collected by MDC and MWRA include many of the sampling parameters needed to assess compliance with State water-quality standards. Thus, these data would be useful in determining use-support of the sampled stream reaches. However, the spatial distribution of sampling sites is limited, and the targeted site-selection approach would make it difficult to extrapolate monitoring results to unsampled streams (see below for further discussion) The MDC and MWRA data, particularly from sites in the relatively pristine Quabbin watershed, however, could be used to characterize background or unimpaired conditions in Massachusetts streams.
The MHD collects water-quality samples primarily from ground water from municipal and private water supplies statewide. This monitoring focuses on contamination associated with road-salt constituents of highway runoff, such as sodium, calcium, and chloride. Although this network might overlap with some fixed sites in a proposed surface-water-quality monitoring network, the limited range of water-quality constituents indicates that this program would provide only ancillary data for other monitoring objectives.

The DFWELE/DMF monitoring program collects environmental data at some 350 sites in the coastal waters of Massachusetts. Primary datacollection efforts focus on bacterial contamination of shellfishing beds. These data have been used for assessing designated uses of coastal waters for the State's 305(b) report and will continue to be very useful for this purpose. The distribution of sampling sites is likely to be based on a targeted approach, however, such that additional data or alternative approaches would be needed to develop a comprehensive assessment of designated use of all coastal waters as defined by 305 (b) purposes. The DFWELE/DFW conducts fish community surveys throughout the State, following the MWI basin cycles, and monitors game fish populations in Quabbin and Wachusett watersheds. These data support use determinations for aquatic life in sampled streams, but would be difficult to extrapolate to unsampled streams.

In addition to the State agencies with responsibilities for monitoring water quality, there are at least 100 local volunteer groups that are concerned with some aspect of water quality. These groups, many of which are associated with the Massachusetts Waterwatch Partnership, generally are distributed throughout the State and may focus their efforts on streams, lakes or ponds, and coastal habitats. Their activities may range from lobbying to occasional monitoring to maintaining a full-time professional staff, such as that of the Charles River Watershed Association. These volunteers can serve as an important part of a statewide water-quality-monitoring network, by collecting reconnaissance or higher-level data, by compiling information on local impairments and pollution sources, and by otherwise supplementing agency programs. Many of these groups are active participants on the MWI basin teams. Volunteer monitoring programs in Massachusetts are summarized in a recent report to EOEA by River Network (Dates and others, 2000). 


\section{TIER I: BASIN-BASED MONITORING PROGRAM FOR THE CLEAN WATER ACT STATEWIDE ASSESSMENT}

\section{Tier I Monitoring Program Objectives and Approaches}

The objective of Tier I of the statewide monitoring program is to provide a periodic assessment of the quality of the State's surface and ground waters, as is required by Section 305(b) of the CWA. The waterquality questions posed by this objective are: (1) what fraction of the State's streams, lakes, ground waters and marine waters support their designated uses, and (2) what are the causes (pollutants or other stressors; U.S. Environmental Protection Agency, 1997a) and sources of impairments, where designated uses are not met. The designated uses for these water body types are defined by the State as primary contact recreation (swimming), secondary contact recreation (boating and fishing), aquatic life support, fish consumption, shellfishing, aesthetics, and drinking water. As stated previously, shellfishing and drinking-water uses and the quality of marine waters and ground waters, which are monitored by agencies other than DEP/DWM, are outside of the scope of the monitoring program described in this report.

Massachusetts Surface-Water Quality Standards (MGL Ch. 21, section 27; 314 CMR 4.00, 1995) provide criteria by which to determine whether water bodies meet their designated uses. The criteria are established in terms of water classes that encompass several uses, but also can be grouped according to the individual designated uses (Kennedy and others, 1995; Commonwealth of Massachusetts, 1997, 1998; A.S. Johnson, Massachusetts Department of Environmental Protection, written commun., 2000). The standards are primarily numeric criteria, such as maximum or minimum acceptable values for $\mathrm{pH}$, temperature, or dissolved oxygen, and can be used to directly define sampling parameters for the monitoring program (table 2). Assessments of use support also include the interpretation of narrative standards, which requires different types of information. For example, the occurrence of nutrient concentrations that encourage cultural eutrophication may be assessed with macrophyte mapping; or macroinvertebrate community indices as well as $\mathrm{pH}$ and dissolved-oxygen concentrations may be used to determine whether a native and diverse aquatic community exists, which is the definition of the aquatic life use (MGL, Ch. 21, section 27 and CMR 4.02, 1995; A.S. Johnson, Massachusetts Department of Environmental Protection, written commun., 1999).

Requirements for a Tier I monitoring program are that it be statewide in scale, comprehensive (all water bodies in the Commonwealth are assessed), and repeated at regular intervals. The need for comprehensive spatial coverage indicates that synoptic-survey, rather than fixed-station monitoring, approaches are appropriate, and that "snapshots" of existing conditions, rather than trend data, are needed. However, short-term temporal variability in water-quality conditions must be measured adequately to determine whether the state numeric water-quality standards are met. The proposed monitoring program also should lead to improvements in the 305(b) assessment, by increasing the number of stream miles and lake acres assessed as compared to previous years and reducing the historical bias towards streams and lakes with known water-quality problems. The requirement of comprehensive ("100 percent") monitoring of all water bodies also means that a probabilistic approach, which provides inferential information on all water bodies by sampling a relatively small number of them, will be needed. In addition, information is needed on causes of impairment and the sources of impairing stressors, as well as on the use-support status of all water bodies, both for the 305(b) assessment and for the basin-based assessments of the MWI teams. Thus, water-quality data are needed at a scale that is sufficiently dense so that existing conditions can be related to land uses and other causes and sources of specific impairments. Finally, Massachusetts' commitment to the watershed-based, rotating-basin approach to waterresource assessment and management requires that a monitoring design for the 305(b) assessment, like other components of a comprehensive statewide monitoring strategy, be integrated with the MWI. Thus, the monitoring program must be designed to be implemented on a 5-year, rotating-basin cycle and should otherwise supplement the missions of the MWI teams. 
[Modified from A. Johnson, Massachusetts Department of Environmental Protection, written commun., 2000. BPJ, best professional judgement; DPH, Massachusetts Department of Public Health;

GM, geometric mean; L-EL, lowest-effect level, or concentration of a contaminant where no adverse effects would be expected; S-EL, severe-effect level, or concentration of a contaminant where severe detrimental effects would be expected; L-EL and S-EL values from Persaud and others, 1992; $n$, number of samples; PCBs, polychlorinated biphenyls; RBP, Rapid bioassessment protocol; TRC, total residual chlorine; $\mu \mathrm{g} / \mathrm{kg}$, microgram per kilogram; $\mathrm{mg} / \mathrm{L}$, milligrams per liter; $\mathrm{mL}$, milliliter; $\mathrm{ng} \mathrm{TEQ} / \mathrm{kg}$, nanogram dioxin toxic equivalents per kilogram; $>$, actual value is greater than or equal to value shown; < actual value is less than or equal to value shown; >, actual value is greater than value shown; <, actual value is less than value shown; \%, percent; ${ }^{\circ} \mathrm{F}$, degrees Fahrenheit; --, no applicable standards]

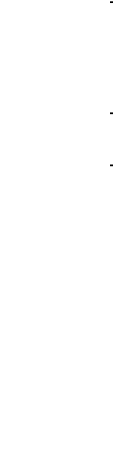

\section{Sampling}

parameter

Water-quality standards

\section{Criteria for determining use-support status}

\begin{tabular}{|c|c|c|c|c|}
\hline \multirow{2}{*}{ parameter } & & \multirow{2}{*}{ Supporting } & \multirow{3}{*}{ Partially supporting } & \multirow{3}{*}{ Not supporting } \\
\hline & & & & \\
\hline \multicolumn{3}{|c|}{ Aquatic-Life Use } & & \\
\hline \multicolumn{5}{|l|}{ Water chemistry } \\
\hline Dissolved oxygen ........................... & $\begin{array}{l}\text { Cold water: } \\
\geq 6.0 \mathrm{mg} / \mathrm{L} \text { and } \geq 75 \% \text { saturation unless } \\
\quad \text { background is lower } \\
\text { Warm water: } \\
\geq 5.0 \mathrm{mg} / \text { and } \geq 60 \% \text { saturation unless } \\
\quad \text { background is lower }\end{array}$ & $\begin{array}{l}\text { Standards met in } \geq 90 \% \text { of } \\
\text { measurements }\end{array}$ & $\begin{array}{l}\text { Standards not met in } 11 \text { to } \\
25 \% \text { of measurements }\end{array}$ & $\begin{array}{l}\text { Standards not met in }>25 \% \\
\text { of measurements }\end{array}$ \\
\hline $\mathrm{pH}$ (standard units) .......................... & $\begin{array}{l}6.5 \text { to } 8.3 \text { and change } \leq 0.5 \text { outside } \\
\text { of background range }\end{array}$ & $\begin{array}{l}\text { Standards met in } \geq 90 \% \text { of } \\
\text { measurements }\end{array}$ & $\begin{array}{c}\text { Standards not met in } 11 \text { to } \\
25 \% \text { of measurements }\end{array}$ & $\begin{array}{l}\text { Standards not met in }>25 \% \\
\text { of measurements }\end{array}$ \\
\hline 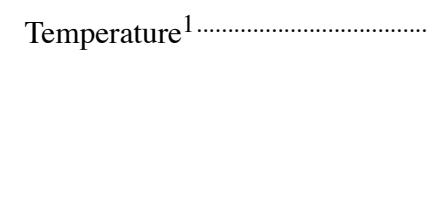 & $\begin{array}{l}\text { Cold water: } \\
\leq 68^{\circ} \mathrm{F} \text { and change } \leq 3^{\circ} \mathrm{F} \text { due to a discharge } \\
\text { Warm water: } \\
\leq 83^{\circ} \mathrm{F} \text { and change } \leq 3^{\circ} \mathrm{F} \text { in lakes and } \leq 5^{\circ} \mathrm{F} \text { in rivers } \\
\quad \text { due to a discharge }\end{array}$ & $\begin{array}{l}\text { Standards met in } \geq 90 \% \text { of } \\
\text { measurements }\end{array}$ & $\begin{array}{l}\text { Standards not met in } 11 \text { to } \\
25 \% \text { of measurements }\end{array}$ & $\begin{array}{l}\text { Standards not met in }>25 \% \\
\text { of measurements }\end{array}$ \\
\hline 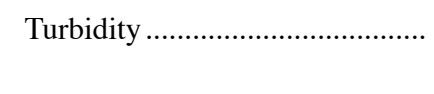 & Narrative standard & $\begin{array}{l}\text { Change } \leq 5 \text { turbidity units } \\
\text { due to a discharge }\end{array}$ & BPJ & BPJ \\
\hline 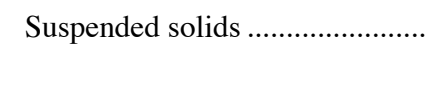 & Narrative standard & $\begin{array}{c}\leq 25 \mathrm{mg} / \mathrm{L} \text { and change } \leq 10 \\
\mathrm{mg} / \mathrm{L} \text { due to a discharge }\end{array}$ & BPJ & BPJ \\
\hline Nutrients ........... & $\begin{array}{l}\text { Narrative standard: Nutrients shall not exceed the } \\
\text { site-specific limits necessary to control } \\
\text { accelerated cultural eutrophication }\end{array}$ & $\begin{array}{l}\text { Site-specific criteria; } \\
\text { maintain balanced } \\
\text { biocommunity; } \\
\text { no pH or dissolved oxygen } \\
\text { violations }\end{array}$ & BPJ & $\mathrm{BPJ}$ \\
\hline Toxic pollutants ............................ & Ammonia $\leq 0.254 \mathrm{mg} / \mathrm{L}$ as $\mathrm{NH}_{3}-\mathrm{N}^{2}$ & Standards met & BPJ & Standards are exceeded in \\
\hline
\end{tabular}

\section{Sediment chemistry and toxicity}

$$
\text { Chlorine } \leq 0.011 \mathrm{mg} / \mathrm{L} \text { TRC }
$$

Ontario guidelines for L-EL and S-EL

Toxic pollutants .

$--$

$<$ L-EL

One pollutant between $\quad$ One pollutant $\geq S$-EL

L-EL and S-EL 
Table 2. Selected surface-water quality standards and criteria for determining use-support status in Massachusetts streams-Continued

\begin{tabular}{|c|c|c|c|c|}
\hline \multirow{2}{*}{$\begin{array}{l}\text { Sampling } \\
\text { parameter }\end{array}$} & \multirow{2}{*}{ Water-quality standards } & \multicolumn{3}{|c|}{ Criteria for determining use-support status } \\
\hline & & Supporting & Partially supporting & Not supporting \\
\hline \multicolumn{5}{|c|}{ Aquatic-Life Use-Continued } \\
\hline & & \multicolumn{3}{|c|}{ Ontario guidelines for L-EL and S-EL } \\
\hline 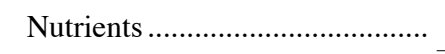 & -- & $<\mathrm{L}-\mathrm{EL}$ & Between L-EL and S-EL & $\geq \mathrm{S}$-EL \\
\hline 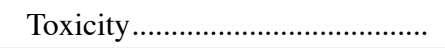 & -- & $>75 \%$ survival & $>50 \%$ and $\leq 75 \%$ survival & $\leq 50 \%$ survival \\
\hline \multicolumn{5}{|l|}{ Biology } \\
\hline Macroinvertebrates ...................... & -- & $\begin{array}{l}\text { Non-impaired based on } \\
\text { RBP II or III }\end{array}$ & $\begin{array}{l}\text { Slightly impaired based on } \\
\text { RBP II or III }\end{array}$ & $\begin{array}{l}\text { Moderately or severely } \\
\text { impaired based on RBP } \\
\text { II or III }\end{array}$ \\
\hline 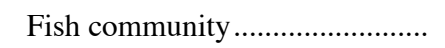 & -- & BPJ & BPJ & BPJ \\
\hline Habitat and flow ........................... & -- & BPJ & BPJ & $\begin{array}{l}\text { Dewatered streambed due } \\
\text { to artificial regulation or } \\
\text { channel alteration }\end{array}$ \\
\hline 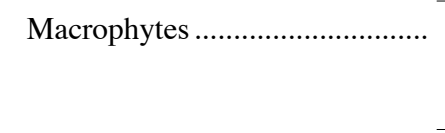 & -- & BPJ & $\begin{array}{l}\text { Non-native plant species } \\
\text { present, but not } \\
\text { dominant, BPJ }\end{array}$ & $\begin{array}{l}\text { Non-native plant species } \\
\text { dominant, BPJ }\end{array}$ \\
\hline Plankton/Periphyton .................... & -- & No algal blooms & Occasional algal blooms & Persistent algal blooms \\
\hline \multicolumn{5}{|l|}{ Tissue chemistry } \\
\hline 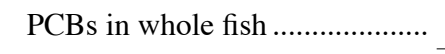 & -- & $\leq 500 \mu \mathrm{g} / \mathrm{kg}$ wet weight & BPJ & BPJ \\
\hline PCBs in aquatic tissue ................. & -- & $\begin{array}{l}<0.79 \mathrm{ng} \mathrm{TEQ} / \mathrm{kg} \text { wet } \\
\text { weight }\end{array}$ & BPJ & BPJ \\
\hline 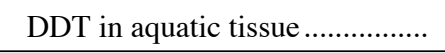 & -- & $\leq 500 \mu \mathrm{g} / \mathrm{kg}$ wet weight & BPJ & BPJ \\
\hline
\end{tabular}

Dry-weather guidance: Maximum of $<400$ colonies/100 $\mathrm{mL}$ for $\mathrm{n}<5$ Wet-weather guidance: $<2,000$ colonies $/ 100 \mathrm{~mL}$

Fecal coliform bacteria............ GM of $<200$ colonies/100 $\mathrm{mL}$ in any representative set of samples and $<10 \%$ of samples $>400$ colonies $/ 100 \mathrm{~mL}$
$\mathrm{pH}$
Standards met in $\geq 90 \%$ of measurements for all samples or dry- and wetweather guidances met

\section{Standards exceeded in} $\leq 10 \%$ of measurements
Standards exceeded in 11 to Standards exceeded in $25 \%$ of samples or dry- $\quad>25 \%$ of samples weather guidance met and wet-weather guidance not met

Standards exceeded in 11 to Standards exceeded in
$25 \%$ of measurements 
Table 2. Selected surface-water quality standards and criteria for determining use-support status in Massachusetts streams-Continued

\begin{tabular}{|c|c|c|c|c|}
\hline \multirow{2}{*}{$\begin{array}{l}\text { Sampling } \\
\text { parameter }\end{array}$} & \multirow{2}{*}{ Water-quality standards } & \multicolumn{3}{|c|}{ Criteria for determining use-support status } \\
\hline & & Supporting & Partially supporting & Not supporting \\
\hline \multicolumn{5}{|c|}{ Primary Contact Recreation Use-Continued } \\
\hline Temperature .................................. & Same as for aquatic life & Standards met & $\begin{array}{l}\text { Standards exceeded in } 11 \text { to } \\
25 \% \text { of measurements }\end{array}$ & $\begin{array}{l}\text { Standards exceeded in } \\
>25 \% \text { of measurements }\end{array}$ \\
\hline Color and turbidity ........................ & Narrative standard & $\begin{array}{c}\text { Change } \leq 5 \text { turbidity units } \\
\text { due to a discharge }\end{array}$ & $\begin{array}{l}\text { Criterion for support } \\
\text { exceeded in } 11 \text { to } 25 \% \text { of } \\
\text { measurements }\end{array}$ & $\begin{array}{l}\text { Criterion for support } \\
\text { exceeded in }>25 \% \text { of } \\
\text { measurements }\end{array}$ \\
\hline Secchi disk depth.......................... & Narrative standard & $\geq 4$ feet & $\begin{array}{l}\text { Infrequent excursions from } \\
\text { the criterion for support }\end{array}$ & $\begin{array}{l}\text { Frequent and(or) prolonged } \\
\text { excursions from the } \\
\text { criterion for support }\end{array}$ \\
\hline Aesthetics-Biocommunity ....... & Narrative standard & $\begin{array}{l}\text { For lakes, macrophyte } \\
\text { cover is }<50 \% \text { at } \\
\text { maximum extent of } \\
\text { growth }\end{array}$ & $\begin{array}{l}\text { For lakes, macrophyte } \\
\text { cover is } 50 \text { to } 75 \% \text { of } \\
\text { lake area at maximum } \\
\text { extent of growth }\end{array}$ & $\begin{array}{l}\text { For lakes, macrophtye } \\
\text { cover is }>75 \% \text { of lake } \\
\text { area at maximum extent } \\
\text { of growth }\end{array}$ \\
\hline
\end{tabular}

Dry-weather guidance: Maximum of $<2,000$ colonies/ $100 \mathrm{~mL}$ for $\mathrm{n}<5$ or $\mathrm{GM}$ of $<1,000$ colonies $/ 100 \mathrm{~mL}$ for $\mathrm{n}>5$ and $<10 \%$ of samples $>2,000$ colonies $/ 100 \mathrm{~mL}$ Wet-weather guidance: $<4,000$ colonies $/ 100 \mathrm{~mL}$

\begin{tabular}{|c|c|c|c|c|}
\hline Fecal coliform bacteria.............. & $\begin{array}{l}\mathrm{GM} \text { of }<1,000 \text { colonies } / 100 \mathrm{~mL} \text { in any } \\
\text { representative set of samples and }<10 \% \text { of } \\
\text { samples }>2,000 \text { colonies } / 100 \mathrm{~mL}\end{array}$ & $\begin{array}{l}\text { Dry- and wet-weather } \\
\text { guidances met }\end{array}$ & $\begin{array}{l}\text { Dry-weather guidance met } \\
\text { and wet-weather } \\
\text { guidance not met }\end{array}$ & $\begin{array}{l}\text { Dry-weather samples } \\
\text { guidance not met }\end{array}$ \\
\hline Aesthetics - Biocommunity ....... & Same as for primary contact recreation & $\begin{array}{l}\text { Same as primary contact } \\
\text { recreation }\end{array}$ & $\begin{array}{l}\text { Same as primary contact } \\
\text { recreation }\end{array}$ & $\begin{array}{l}\text { Same as primary contact } \\
\text { recreation }\end{array}$ \\
\hline \multicolumn{5}{|c|}{ Aesthetics Use } \\
\hline $\begin{array}{l}\text { Aesthetics-Visual } \\
\text { observation }\end{array}$ & $\begin{array}{l}\text { No objectionable bottom deposits, floating debris, } \\
\text { scum, or nuisances; } \\
\text { No objectionable odor, color, taste, or turbidity, or } \\
\text { nuisance aquatic life }\end{array}$ & Criteria met & $\begin{array}{l}\text { Objectionable conditions } \\
\text { neither frequent or } \\
\text { prolonged, BPJ }\end{array}$ & $\begin{array}{l}\text { Objectionable conditions } \\
\text { frequent and(or) } \\
\text { prolonged, BPJ }\end{array}$ \\
\hline \multicolumn{5}{|c|}{ Fish Consumption Use } \\
\hline $\begin{array}{l}\text { DPH Fish Consumption } \\
\quad \text { Advisory List .............................. }\end{array}$ & -- & $\begin{array}{l}\text { Not applicable, precluded } \\
\text { by statewide advisory for } \\
\text { mercury }\end{array}$ & Not applicable & $\begin{array}{l}\text { Water body is on DPH Fish } \\
\text { Consumption Advisory } \\
\text { List }\end{array}$ \\
\hline
\end{tabular}

\footnotetext{
${ }^{1}$ Maximum daily mean temperature in one month, from at least 6 measurements evenly distributed over 24 hours.

${ }^{2}$ Ammonia concentration varies with $\mathrm{pH}$; value shown is for $\mathrm{pH}$ equal to 9.0.
} 


\section{Tier I Monitoring Design for the Neponset River Basin}

A monitoring design for Tier I of the statewide program was developed using the Neponset River Basin in Eastern Massachusetts as an example. The Neponset basin was used as a pilot for the Massachusetts Watershed Initiative (MWI) in the early 1990s (Kennedy and others, 1995). It was chosen as the study area for the current effort to take advantage of the extensive data collected in the MWI pilot and to compare the MWI pilot approach to that of the monitoring network proposed here. The Neponset Basin is a 117square-mile watershed that is drained by the Neponset River to Dorchester Bay (Boston Harbor) in Quincy, Mass. (fig. 2). It is divided into 14 tributary subbasins, which are inventory, planning, and communityorganizational units (fig. 2; Warren Kimball, Massachusetts Department of Environmental Protection, oral commun., 1998; Russell Cohen, Massachusetts Department of Fisheries, Wildlife, and Environmental Enforcement, oral commun., 1999). Land use within the basin is 19 percent urban, 35 percent residential, and 48 percent forest cover and other undeveloped land (including 2 percent agricultural land use).

\section{Definition of Water Resources in the Basin}

\section{Data Sources}

The first step in a comprehensive assessment of water resources in an area is to inventory the water resources, that is, to define the population of water bodies to be assessed (Gilbert, 1987). Streams and lakes in the Neponset Basin were inventoried using centerline hydrographic data at 1:25,000-scale developed by Massachusetts Office of Information and Environmental Information (MassGIS) of the Executive Office of Environmental Affairs (EOEA) and the USGS (fig. 2). Hydrography at the 1:25,000-scale corresponds to streams, lakes and ponds, and other water resources represented on the 7.5- by 15 -minute USGS topographic quadrangles. The MassGIS centerline data, originally derived from the quadrangle hydrography, are the standard digital data used by MWI teams and other state agencies for surface-water mapping, planning, analysis, and management at the major-basin and larger scales; the MassGIS data also are increasingly used by municipalities and local organizations for these purposes. The MassGIS 1:25,000 digital hydrography is directly linked to DEP's SARIS and PALIS inventory systems (Halliwell and others, 1982; Ackerman and others, 1984; Ackerman, 1989) for streams and lakes, respectively. The MassGIS data are not currently linked to the USEPA river reach data set (RF3 or the National Hydrography Dataset, NHD) that USEPA is recommending for mapping and analysis of 305(b) assessment data (U.S. Environmental Protection Agency, 1997a, 1997c). The NHD, however, is at a scale of 1:100,000; which does not provide the resolution needed by the MWI teams and DEP/DWM for water-quality monitoring, assessment, or management decisions within the 27 individual major basins in Massachusetts; it also was not available at the time of this analysis. It should be noted that the MassGIS 1:25,000 data could be readily linked to the USEPA river reach data, when a final version of that data set is available.

\section{Streams}

Streams are linear features that theoretically can be assessed at an infinite number of point locations along the stream network. In practice, streams may be inventoried in terms of length (stream miles) and (or) in terms of sections or reaches that are defined by physical boundaries, such as confluences with other streams or watershed boundaries. The DEP's SARIS system, which identifies named streams of varying length that are classified by major basin (Halliwell and others, 1982), is an example of an inventory based on stream reaches. The approach used here for inventorying streams in the Neponset Basin is guided by the need for a conceptual definition of lengths of stream within which the water-quality conditions of interest are expected to be uniform; this is a general need of most stream water-quality assessments, where conditions in stream reaches must be determined by extrapolating point sampling data. Lengths of streams with uniform water quality depend on inputs, outputs, and instream transformation or attenuation processes, which vary by contaminant. Thus, it is not possible to define in advance a length of stream for which one sample would be representative for all contaminants under all circumstances of hydrologic conditions and land use or other contamination inputs. 


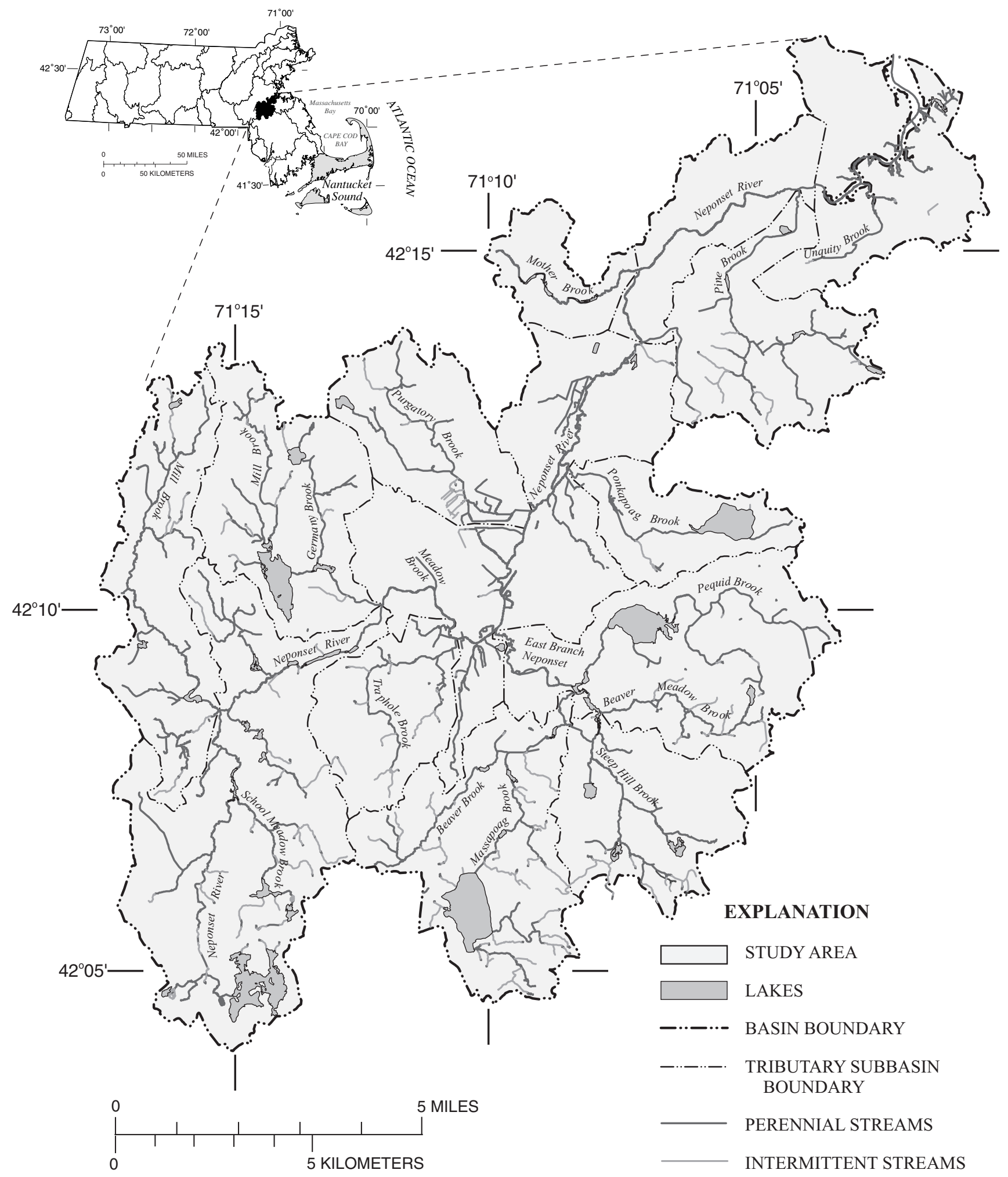

Figure 2. The Neponset Basin in eastern Massachusetts. 
USEPA guidelines address this issue by stating that "a monitoring station can be considered representative of a stream water body for a distance upstream and downstream that has no significant influences that might tend to change water quality or habitat quality;" such influences are listed as point or non-point sources to a stream or tributary, changes in land use or other watershed characteristics, changes in streambank characteristics, large tributaries, or hydrologic features such as dams (U.S. Environmental Protection Agency, 1997a, p. 2-1).

Streams in the Neponset Basin were inventoried for the network design using a systematic, relatively unbiased approach to defining stream lengths expected to have relatively uniform water quality that could be represented by a single sample. Thus, stream reaches were delineated using confluences with tributaries, significant lakes, and point-source discharges. These features correspond to potential inputs, outputs, or transformations of stream-water contaminants in a stream reach. A confluence with a tributary potentially changes water quality in a stream when the tributary water carries contaminants, or contaminants in the stream are diluted through the addition of cleaner tributary water. Transport through lakes potentially changes water quality through changes in flow, such that particulates and associated contaminants (for example, metals) may settle, or through transformation of biologically active contaminants such as nutrients. Flow through stream reaches bordered by extensive wetlands also may have these effects; however, wetlands were not used to delineate stream segments because of the indeterminate effects wetlands have on water quality and because detailed spatial data for wetlands were not available. Point-source discharges may alter streamwater quality through direct input of contaminants or through changes in the physical properties (temperature, $\mathrm{pH}$ ) of the stream water. The physical characteristics of tributary confluences, lakes, and point-source discharges can be consistently determined for any basin, are generally applicable for many contaminants, and do not require relatively subjective judgments (such as judgments about the effects of land use on water quality).

Permitted discharges under the NPDES program were used to represent significant pointsource discharges to the streams in the basin, for the purposes of defining stream segments. Information on NPDES dischargers was obtained from the Permit Compliance System of USEPA Region I (N. Mason,
U.S. Environmental Protection Agency, Boston, Mass., written commun., July and August, 1998; U.S. Environmental Protection Agency, 1998a) and from the 1994 DEP assessment of the basin (Kennedy and others, 1995). A digital data layer of NPDES discharger locations was obtained from DEP (Brian Brodeur, Massachusetts Department of Environmental Protection, 1998). This information was reviewed to identify discharges with the potential for measurable effects on stream-water quality, based on information provided in the discharge permits (table 3 ).

Stream segments were delineated in ARC/INFO as described in the appendix. Only streams coded as perennial in the MassGIS data layer were included (fig. 2). Streams were divided at confluences with perennial tributaries greater than $328 \mathrm{ft}(100 \mathrm{~m})$ in length. Streams also were divided at inlets and outlets of significant lakes (see "Lakes" section, below, for further discussion) and at NPDES locations. The stream segmentation scheme is illustrated for a small portion of the basin in figure 3 (note that streamsegment boundaries are at small distances up- and downstream from confluences, lakes, and NPDES sites, as explained in the appendix). Stream order was determined for all perennial streams in the basin, and stream order was retained as an attribute of each stream segment. Stream order is a classification scheme that can be used as a surrogate for relative stream size; this was defined using the Strahler method (Gordon and others, 1992). First-order streams are small streams at the headwaters of drainages with no tributaries draining to them; second-order streams are formed by the junction of two first-order streams; third-order streams are formed by the junction of two second-order streams, and so on (Gordon and others, 1992). Finally, watershed areas were delineated for each stream segment by using the MassGIS Watershed Analyst (MassGIS, 2000b) as described in the appendix.

Summary statistics on number, length, stream order, and watershed area of perennial stream segments in the basin are presented in table 4 . Three hundred and twelve stream segments were delineated, comprising a total of 152.6 stream miles. About half of the segments (51 percent) and stream miles (47 percent) were firstorder streams (fig. 4A). Watershed of first-order streams were nearly all less than one-half square mile in area. Twenty-seven percent of stream miles were second-order, 18 percent were third order, 6 percent were fourth order, and 8 percent were fifth order; the distribution of stream segments was similar to that of stream miles (table 4). Second- and third-order streams 
Table 3. Discharges permitted under the National Pollutant Discharge Elimination System that were used in defining stream segments for Tier I monitoring in the Neponset Basin, Massachusetts

[Status of permit: Status as of December 1998. BOD-5, 5-day biological oxygen demand; TSS, total suspended solids; gal/d, gallons per day]

\begin{tabular}{|c|c|c|c|c|c|}
\hline Facility name & $\begin{array}{l}\text { Type of } \\
\text { discharge }\end{array}$ & $\begin{array}{l}\text { Status of } \\
\text { permit }\end{array}$ & \multicolumn{2}{|l|}{ Type of discharge } & $\begin{array}{c}\text { Permitted } \\
\text { discharge } \\
\text { volume }\end{array}$ \\
\hline 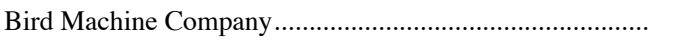 & major & active & \multicolumn{2}{|c|}{ stormwater and noncontact cooling water } & unknown \\
\hline 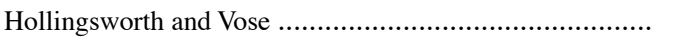 & minor & active & \multicolumn{2}{|c|}{ strainer backwash and process water } & $700,000 \mathrm{gal} / \mathrm{d}$ \\
\hline Bird Roofing, Inc... & minor & active & \multicolumn{2}{|l|}{ stormwater } & $40,000 \mathrm{gal} / \mathrm{d}$ \\
\hline Plymouth Rubber Company........... & major & active & \multicolumn{2}{|c|}{ stormwater and noncontact cooling water } & $2,600,000 \mathrm{gal} / \mathrm{d}$ \\
\hline 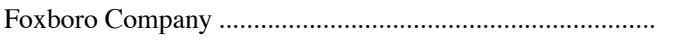 & minor & active & \multicolumn{2}{|c|}{ stormwater and noncontact cooling water } & $320,000 \mathrm{gal} / \mathrm{d}$ \\
\hline 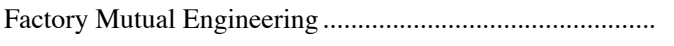 & minor & active & \multicolumn{2}{|l|}{ runoff from equipment testing } & $15,000 \mathrm{gal} / \mathrm{d}$ \\
\hline 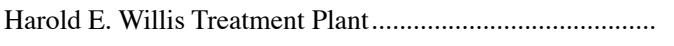 & minor & unknown & \multicolumn{2}{|l|}{ backwash from water-supply plant } & unknown \\
\hline \multirow[t]{2}{*}{ Senior Flexonics/ Metal Bellows Corporation............................ } & minor & unknown & unknown & & unknown \\
\hline & \multicolumn{3}{|c|}{ Effluent standard parameters } & \multicolumn{2}{|c|}{ Receiving water } \\
\hline 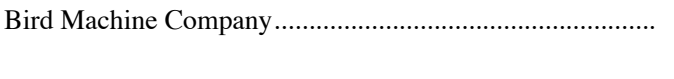 & \multicolumn{3}{|c|}{$\begin{array}{l}\text { temperature, } \mathrm{pH} \text {, phosphorus, copper, lead, zinc, TSS, oil and } \\
\text { grease }\end{array}$} & \multicolumn{2}{|c|}{ Upper Neponset River } \\
\hline 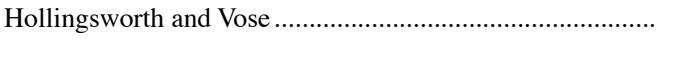 & \multicolumn{3}{|c|}{$\begin{array}{l}\text { temperature, } \mathrm{pH} \text {, dissolved oxygen, phosphorous, zinc, TSS, } \\
\text { settleable solids, BOD-5, toxicity }\end{array}$} & \multicolumn{2}{|c|}{ Middle Neponset River } \\
\hline 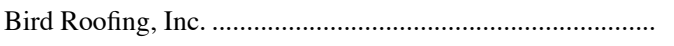 & \multicolumn{3}{|c|}{ temperature, $\mathrm{pH}, \mathrm{TSS}$, oil and grease } & \multicolumn{2}{|c|}{ Middle Neponset River } \\
\hline 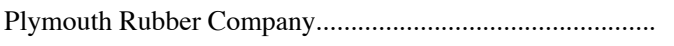 & \multicolumn{3}{|c|}{ temperature, $\mathrm{pH}$, copper, TSS, oil and grease } & \multicolumn{2}{|c|}{ East Branch Neponset River } \\
\hline 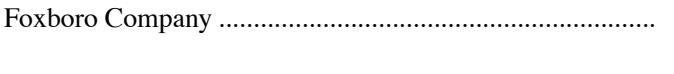 & \multicolumn{3}{|c|}{$\begin{array}{l}\text { temperature, } \mathrm{pH} \text {, fecal coliform bacteria, oil and grease, } \\
\text { toxicity }\end{array}$} & \multicolumn{2}{|c|}{ Neponset Reservoir } \\
\hline 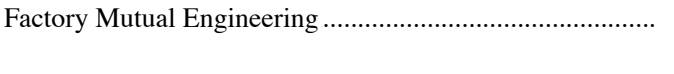 & \multicolumn{3}{|c|}{$\begin{array}{l}\text { temperature, } \mathrm{pH} \text {, mercury, TSS, fecal coliform bacteria, oil } \\
\text { and grease, toxicity }\end{array}$} & \multicolumn{2}{|c|}{ Neponset Reservoir } \\
\hline 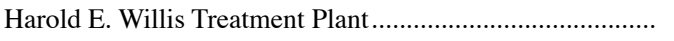 & \multicolumn{3}{|l|}{ unknown } & \multicolumn{2}{|c|}{ Mine Brook } \\
\hline Senior Flexonics/ Metal Bellows Corporation............................ & unknown & & & School M & dow Brook \\
\hline
\end{tabular}

included the major streams draining the 14 tributary subbasins as well as some smaller streams (fig. $4 B-C$ ). Fourth-order streams consisted primarily of the East Branch Neponset River and parts of the mainstem Neponset River upstream from the junction with the East Branch (fig. 4D). The only fifth-order stream in the basin was the mainstem of the Neponset River downstream from the East Branch (fig. $4 E$ ).

Most (83 percent) stream segments were delineated based on confluences with tributaries, the most important factor in determining segment length. The average length of stream segments for all stream orders was about one-half mile, with median length for all but third-order streams about one-third mile. This level of segmentation is most appropriate for small (first- and second-order) streams, which commonly are represented by single segments. However, it is recognized that dividing larger (fourth- and fifth-order) streams at every tributary confluence probably results in more stream segments than necessary to characterize waterquality conditions in these streams, because small tributaries flowing directly to large streams may have negligible effects on the larger streams' quality. However, in urban areas, such as parts of the Lower Neponset River, small tributaries may have disproportionately large effects on water quality; these tributaries, as culverted streams, may drain heavily developed areas that are larger than the length or order of the streams would suggest. The stream inventory procedures described here could be extended by using basinspecific information to identify and retain small tributaries draining relatively large urban areas, which would be likely to affect water-quality in larger streams, and, conversely, to eliminate other small tributaries, not expected to have significant effects. 


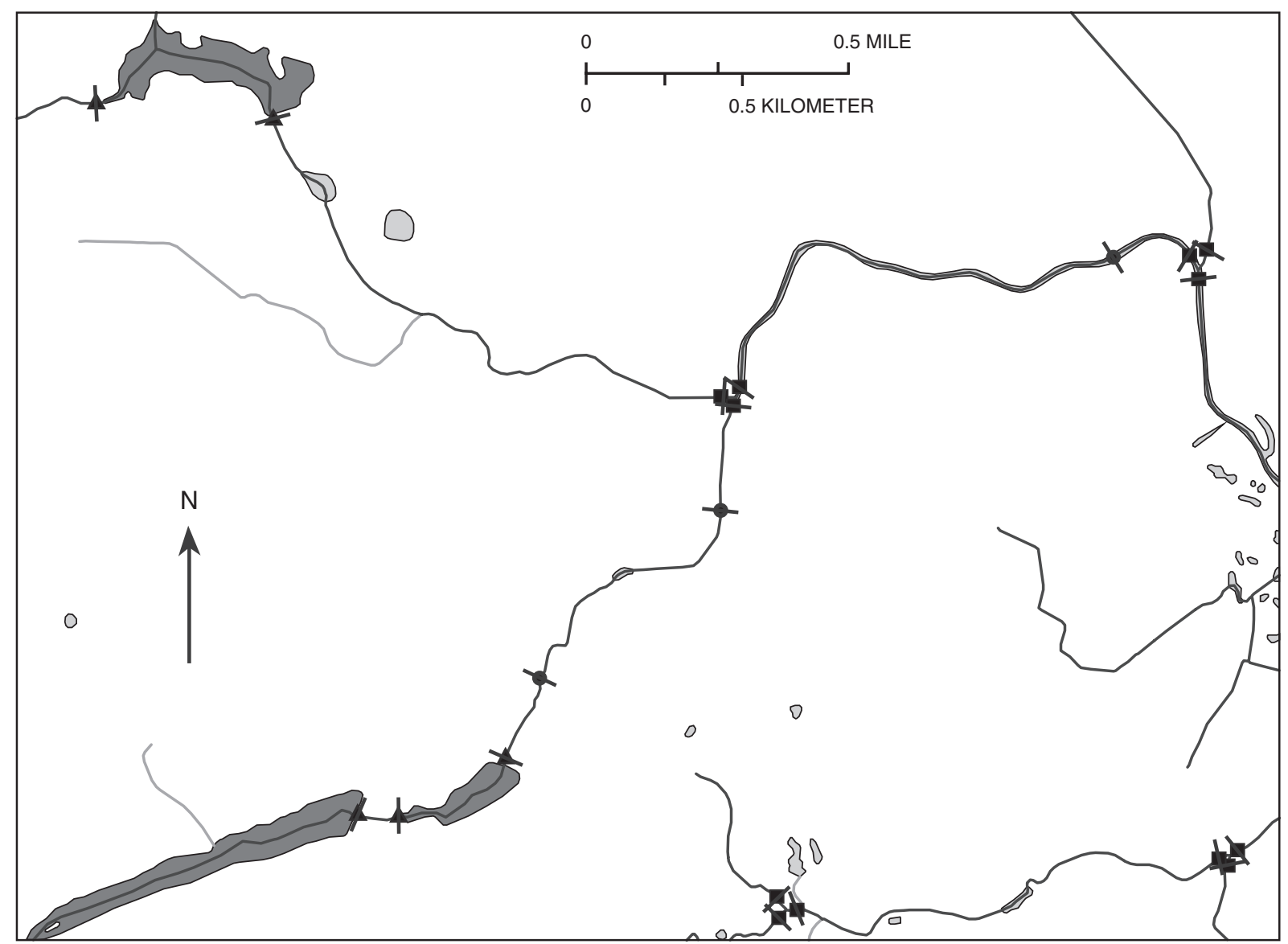

EXPLANATION

LAKES GREATER THAN 5 ACRES IN AREA

LAKES LESS THAN 5 ACRES IN AREA

PERENNIAL STREAM CENTERLINE

INTERMITTENT STREAM CENTERLINE

APPROXIMATE BOUNDARY OF STREAM SEGMENT—Segments defined by:

- Confluences with tributaries

A Significant lakes

- NPDES point discharges

Figure 3. Criteria for segmenting stream hydrography for Tier I monitoring in the Neponset Basin, Massachusetts. 
Table 4. Summary statistics for stream miles and segments inventoried for Tier I monitoring in the Neponset Basin, Massachusetts

\begin{tabular}{|c|c|c|c|c|c|c|}
\hline \multirow{3}{*}{ Stream order } & \multirow{3}{*}{$\begin{array}{c}\text { Total } \\
\text { stream } \\
\text { miles }\end{array}$} & \multicolumn{5}{|c|}{ Stream segments } \\
\hline & & \multirow[b]{2}{*}{ Number } & \multicolumn{4}{|c|}{ Length, in miles } \\
\hline & & & Average & Median & $\begin{array}{c}\text { 25th } \\
\text { percentile }\end{array}$ & $\begin{array}{c}\text { 75th } \\
\text { percentile }\end{array}$ \\
\hline 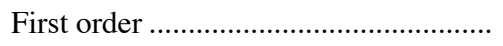 & 72.2 & 158 & 0.46 & 0.31 & 0.15 & 0.61 \\
\hline 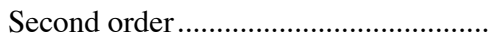 & 31.6 & 58 & .54 & .32 & .20 & .86 \\
\hline 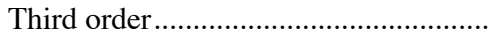 & 28.1 & 47 & .60 & .52 & .24 & .89 \\
\hline 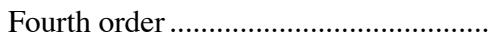 & 8.7 & 25 & .35 & .17 & .12 & .49 \\
\hline Fifth order & 12.0 & 24 & .50 & .28 & .19 & .57 \\
\hline \multirow[t]{4}{*}{ All stream orders } & 152.6 & 312 & 0.49 & 0.26 & 0.16 & 0.71 \\
\hline & & \multicolumn{5}{|c|}{ Stream segments } \\
\hline & & & \multicolumn{4}{|c|}{ Watershed area, in square miles } \\
\hline & & Number & Average & Median & $\begin{array}{c}\text { 25th } \\
\text { percentile }\end{array}$ & $\begin{array}{c}\text { 75th } \\
\text { percentile }\end{array}$ \\
\hline 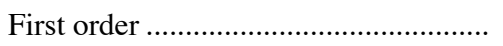 & 72.2 & 158 & 0.37 & 0.19 & 0.05 & 0.45 \\
\hline Second order......... & 31.6 & 58 & 1.53 & 1.05 & .63 & 2.49 \\
\hline 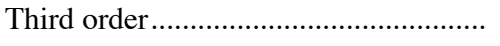 & 28.1 & 47 & 4.65 & 4.57 & 2.14 & 6.16 \\
\hline 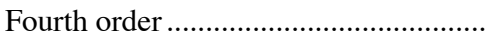 & 8.7 & 25 & 28.1 & 25.8 & 22.3 & 37.6 \\
\hline 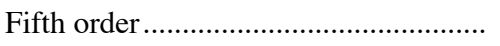 & 12.0 & 24 & 86.3 & 88.7 & 77.4 & 91.7 \\
\hline 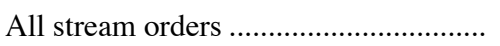 & 152.6 & 312 & 9.55 & 0.72 & 0.15 & 4.18 \\
\hline
\end{tabular}

\section{Lakes}

Lakes in the Neponset Basin were inventoried for the network design by selecting all lakes and ponds represented in the 1:25,000-scale hydrography data layer that were larger than 5 acres, as described in the appendix (fig. 4F). The 5-acre threshold was selected in consultation with DEP/DWM as a criterion to define the significant lakes in a basin that should be included in a comprehensive, basin- or state-wide assessment. Lakes or lake polygons less than 5 acres (including 22 lakes with PALIS codes) were numerous, but represented only 16 percent of the total lake acres in the basin. Additional lakes from the excluded subset could be added to the target population for the assessment as desired. The 46 lakes larger than 5 acres included 40 named, PALIS-coded lakes and 6 unnamed lakes (table 5). Most were less than 35 acres and occurred on all except fifth-order streams. Five lakes, located on second- and third-order streams, were greater than 200 acres.

\section{Sampling Designs}

For a comprehensive assessment of water resources in the Neponset Basin as required by Section 305(b) of the CWA, water-quality information is needed for all stream segments and lakes identified in the basin inventory. Theoretically, this information could be obtained by (1) directly sampling all stream segments and lakes ("exhaustive" approach), or (2) sampling a randomly selected subset of stream segments and lakes and inferring conditions in the rest of the population from the sampled subset ("probabilistic" approach). In practice, an exhaustive approach is almost never possible because of resource limitations. Although it is understood that its implementation is not possible, the exhaustive approach was investigated at the request of DEP/DWM, along with other approaches, to better define the issues and limitations relevant to sampling designs for a comprehensive assessment. Finally, it should be noted that, although the spatial coverage of the exhaustive approach is unrealistic, the discussion of the sampling parameters and frequency in this section is applicable to all the sampling approaches discussed for Tier I monitoring. 


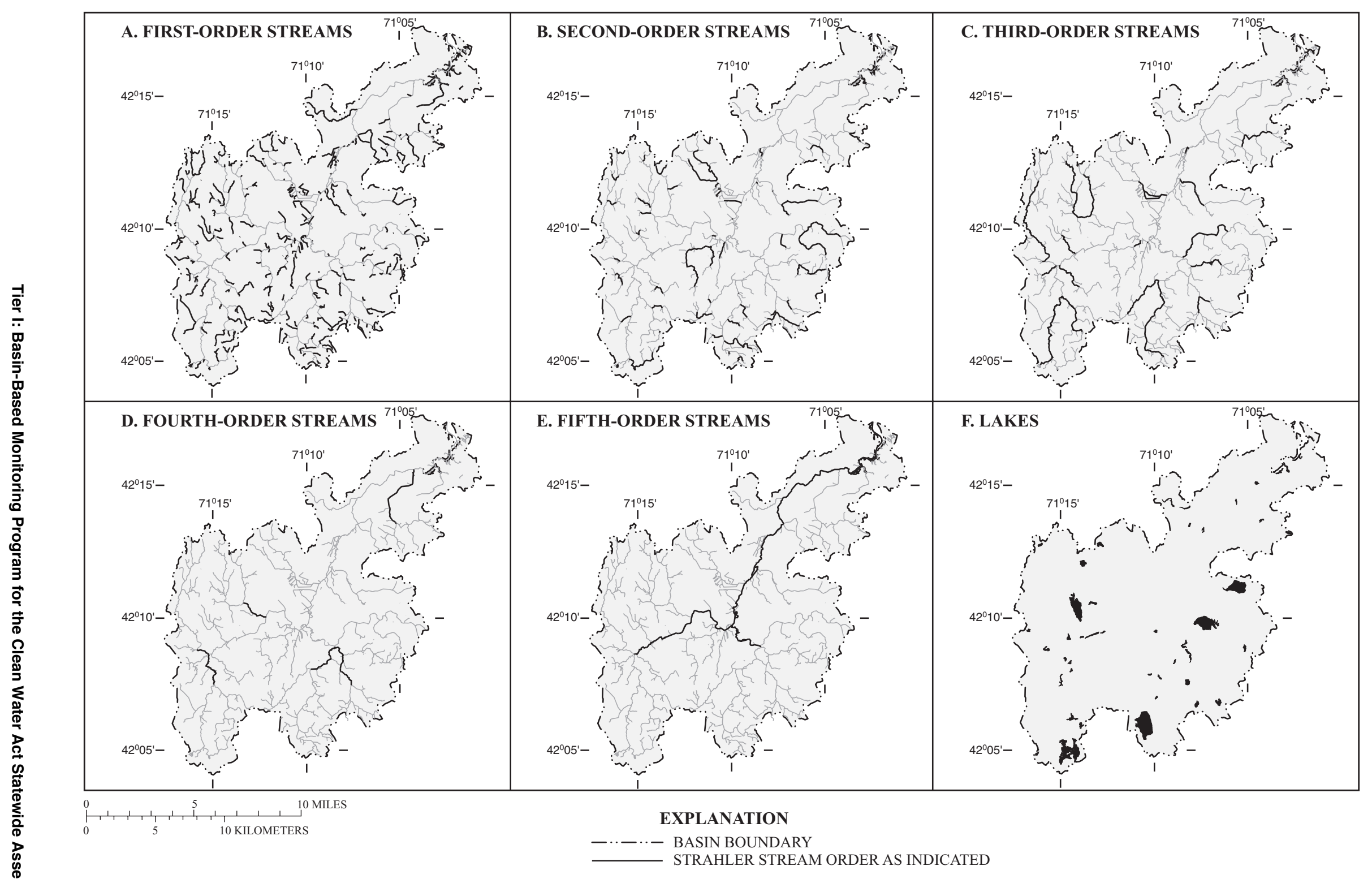

Figure 4. Perennial streams by stream order and lakes inventoried for Tier I monitoring in the Neponset River Basin, Massachusetts. 
Table 5. Physical characteristics of lakes inventoried for Tier I monitoring in the Neponset Basin, Massachusetts

[ID: Unique identification number assigned to point along stream centerline data layer at lake outlet. PALIS-ID: Massachusetts Department of Environmental Management lake inventory code. Strahler order of stream segment: Value of 0 indicates lake is on an intermittent stream, value of 99 indicates lake does not lie on the stream network. --, not determined]

\begin{tabular}{|c|c|c|c|c|c|c|c|}
\hline \multirow{2}{*}{ Lake name } & \multirow{2}{*}{ Tributary basin } & \multirow{2}{*}{ ID } & \multirow{2}{*}{ PALIS-ID } & \multirow{2}{*}{$\begin{array}{l}\text { Lake-surface } \\
\text { area, in acres }\end{array}$} & \multirow{2}{*}{$\begin{array}{l}\text { Strahler order } \\
\text { of stream } \\
\text { segment }\end{array}$} & \multicolumn{2}{|c|}{ Watershed area } \\
\hline & & & & & & Acres & Square miles \\
\hline Avery School Pond.... & Mother Brook & 888 & 73001 & 6.44 & 1 & -- & -- \\
\hline 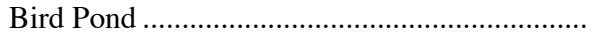 & Upper Neponset & 416 & 73002 & 20.43 & 4 & 16,200 & 25.31 \\
\hline Blue Hills Pond/ Russell Pond .............................. & Pine Tree Brook & 392 & 73003 & 8.94 & 3 & 970 & 1.52 \\
\hline 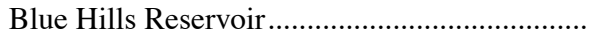 & Pine Tree Brook & 393 & 73004 & 12.17 & 1 & 62.3 & 0.10 \\
\hline Bolivar Pond (Ames Pond) ................................. & East Branch Neponset & 427 & 73005 & 19.79 & 4 & 6,380 & 9.97 \\
\hline 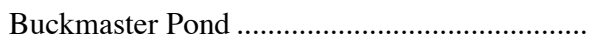 & Hawes Brook & 396 & 73006 & 34.32 & 2 & 329 & 0.51 \\
\hline 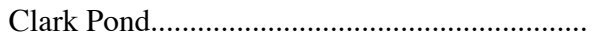 & Upper Neponset & 440 & 73008 & 6.71 & 1 & 739 & 1.16 \\
\hline 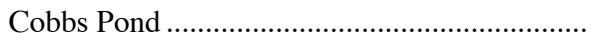 & Upper Neponset & 421 & 73009 & 14.25 & 3 & 1,168 & 1.82 \\
\hline Cranberry Bog Pond........................................... & Upper Neponset & 472 & 73011 & 8.12 & 0 & 78.4 & 0.12 \\
\hline Diamond Pond (Sawmill Pond) …......................... & Upper Neponset & 432 & 73012 & 7.98 & 1 & 1,285 & 2.01 \\
\hline East Dedham Pond ............................................... & Mother Brook & 389 & 73016 & 7.89 & 1 & 1,002 & 1.57 \\
\hline Ellis Pond & Hawes Brook & 405 & 73018 & 17.05 & 3 & 4,883 & 7.63 \\
\hline 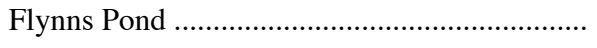 & Mill/Mine Brook & 409 & 73019 & 7.50 & 1 & 104 & 0.16 \\
\hline 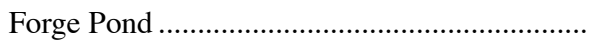 & East Branch Neponset & 476 & 73020 & 8.00 & 3 & 4,274 & 6.68 \\
\hline Ganawatte Farm Pond/ Pine Street Pond ......... & Upper Neponset & 455 & 73037 & 29.45 & 2 & 731 & 1.14 \\
\hline Glen Echo Lake (York Pond) ................................ & East Branch Neponset & 430 & 73022 & 15.75 & 1 & 58.6 & 0.09 \\
\hline Lymans Pond/Gay Street Pond ............................ & Purgatory Brook & 394 & 73021 & 25.13 & 1 & 144 & 0.22 \\
\hline 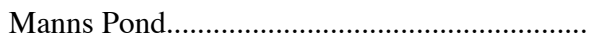 & Massapoag Brook & 450 & 73028 & 5.73 & 3 & 28,140 & 4.40 \\
\hline 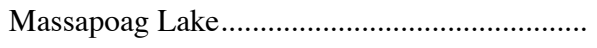 & Massapoag Brook & 454 & 73030 & 389.0 & 3 & 2,321 & 3.63 \\
\hline Mother Brook Pond............................................... & Mother Brook & 388 & 73031 & 8.27 & 1 & 1,358 & 2.12 \\
\hline 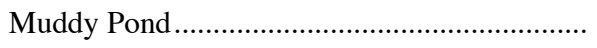 & Steep Hill Brook & 453 & 73033 & 19.77 & 1 & 261 & 0.41 \\
\hline 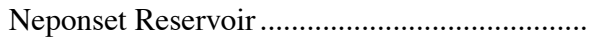 & Upper Neponset & 471 & 73034 & 310.2 & 2 & 1,093 & 1.71 \\
\hline Neponset River Pond............................................ & Neponset Estuary & 367 & 73035 & 10.72 & 3 & 144 & 0.23 \\
\hline 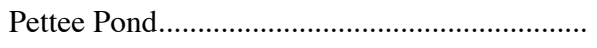 & Hawes Brook & 477 & 73036 & 9.53 & 2 & 2,360 & 3.69 \\
\hline 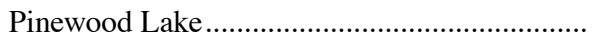 & Steep Hill Brook & 447 & 73039 & 25.20 & 1 & 298 & 0.47 \\
\hline
\end{tabular}


Table 5. Physical characteristics of lakes inventoried for Tier I monitoring in the Neponset Basin, Massachusetts-Continued

\begin{tabular}{|c|c|c|c|c|c|c|c|}
\hline \multirow{2}{*}{ Lake name } & \multirow{2}{*}{ Tributary basin } & \multirow{2}{*}{ ID } & \multirow{2}{*}{ PALIS-ID } & \multirow{2}{*}{$\begin{array}{l}\text { Lake-surface } \\
\text { area, in acres }\end{array}$} & \multirow{2}{*}{$\begin{array}{c}\text { Strahler order } \\
\text { of stream } \\
\text { segment }\end{array}$} & \multicolumn{2}{|c|}{ Watershed area } \\
\hline & & & & & & Acres & Square miles \\
\hline Plimpton Pond & Upper Neponset & 418 & 73041 & 6.37 & 4 & 15,850 & 24.77 \\
\hline 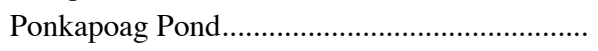 & Ponkapoag Brook & 397 & 73043 & 213.8 & 2 & 1,155 & 1.80 \\
\hline 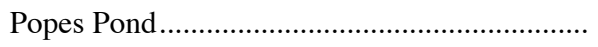 & Pine Tree Brook & 385 & 73044 & 5.97 & 3 & 3,739 & 5.84 \\
\hline 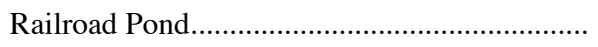 & Upper Neponset & 434 & 73046 & 8.07 & 1 & 1,023 & 1.60 \\
\hline 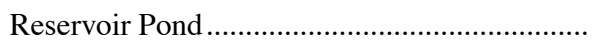 & East Branch Neponset & 408 & 73048 & 251.3 & 3 & 3,908 & 6.11 \\
\hline Sawmill Pond .... & Massapoag Brook & 442 & 73049 & 5.89 & 2 & 16,190 & 2.53 \\
\hline Shephard Pond . & Massapoag Brook & 433 & 73068 & 5.58 & 3 & 6,439 & 10.06 \\
\hline 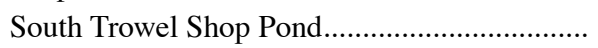 & Massapoag Brook & 444 & 73050 & 8.29 & 3 & 3,883 & 6.07 \\
\hline South Walpole Street Pond.................................... & Upper Neponset & 473 & 73052 & 16.71 & 1 & 200 & 0.31 \\
\hline 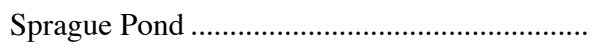 & Middle Neponset & 475 & 73053 & 7.44 & 99 & 71 & 0.11 \\
\hline Stoughton Pond/ Woods Pond................................ & Steep Hill Brook & 452 & 73055 & 28.54 & 1 & 117 & 0.18 \\
\hline Town Pond & Steep Hill Brook & -- & 73056 & 8.13 & 2 & 1,561 & 2.44 \\
\hline 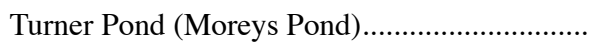 & Mill/Mine Brook & 429 & 73058 & 17.65 & 4 & 4,467 & 6.98 \\
\hline Turners Pond & Pine Tree Brook & 25 & 73059 & 10.53 & 1 & 99.2 & 0.15 \\
\hline Unnamed lake ................................................. & East Branch Neponset & 423 & none & 10.79 & 4 & 17,470 & 27.30 \\
\hline 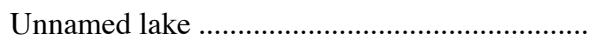 & Middle Neponset & 470 & none & 7.38 & 0 & 31 & 0.05 \\
\hline 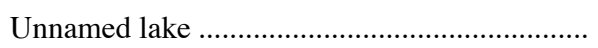 & Middle Neponset & 412 & none & 8.67 & 1 & 53.7 & 0.08 \\
\hline 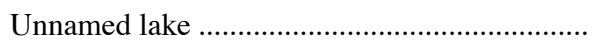 & Mill/Mine Brook & 474 & none & 11.31 & 0 & 175 & 0.27 \\
\hline 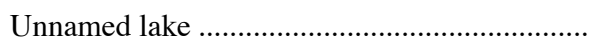 & Upper Neponset & 411 & none & 5.96 & 4 & 162,900 & 25.45 \\
\hline 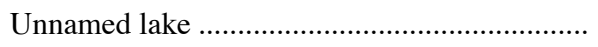 & Upper Neponset & 443 & 504 & 13.66 & 3 & 6,961 & 10.88 \\
\hline 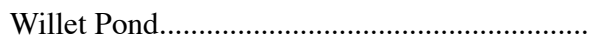 & Hawes Brook & 404 & 73062 & 205.6 & 2 & 3,097 & 4.84 \\
\hline
\end{tabular}




\section{Exhaustive Approach}

\section{Sampling Sites, Parameters, and Frequency}

Sampling sites for the exhaustive approach corresponded to the 312 stream segments and 46 lakes identified in the Neponset Basin, or 357 potential sampling sites. However, it is expected that a basinspecific review of the stream-segment array would lead to a reduction in the number of stream segments on high-order streams; this is addressed further in the "Resource Requirements" section, below. Sampling parameters for the exhaustive approach also were selected to provide data to evaluate all numeric and narrative criteria in the State water-quality standards. The sampling parameters and frequency proposed for this approach are given in table 6. Differences in sampling parameters and frequency between lakes and streams are based on differences in physical, hydrologic, and ecological characteristics; sampling parameters and frequencies that vary by stream order are based on the assumption that stream order is a surrogate for stream size and flow characteristics.

State water-quality standards require that dissolved-oxygen concentrations remain above a minimum concentration (unless decreased by natural causes) and that natural variations in concentration are maintained to support the aquatic life use (table 2). Temperature must be below a maximum value and must not vary by greater than specified values for cold- or warm-water fisheries. Dissolved-oxygen concentrations, $\mathrm{pH}$, and temperature may vary seasonally and daily. In lakes, dissolved oxygen also varies by depth. Ideally, dissolved-oxygen concentrations and temperature would be measured continuously to determine use support, but this is well beyond the scope of a 305(b)-type assessment. In addition, dissolved-oxygen measurements to depict "worst case" conditions should be made in the pre-dawn hours, when dissolved oxygen typically is at a minimum. It is proposed that field parameters of dissolved oxygen, temperature, and $\mathrm{pH}$ be measured repeatedly in streams from March to midOctober in conjunction with bacteria sampling (see below); specific conductance and turbidity also are proposed, as measures of general water quality and suspended solids, respectively. In lakes, measurements should be made at least once, during mid- to late summer, at multiple depths, but are proposed for spring and fall also in conjunction with other measurements. Ideally, dissolved oxygen, temperature, $\mathrm{pH}$, and other field parameters (specific conductance) also could be measured every time a stream or lake is monitored, because these field parameters are easy and inexpensive to measure and provide valuable information on water-quality conditions.

Water-quality standards for fecal-coliform bacteria, an indicator of sewage contamination, specify maximum concentrations, as geometric means of multiple samples, to support primary and secondary contact recreation uses. E. coli is another, commonly sampled fecal-indicator bacteria that future standards could include. Bacteria concentrations in surface waters are variable and highly dependent on stormwater flows. For second- through fifth-order streams, it is proposed that bacteria (fecal coliform and E. coli) be sampled monthly from March to mid-October (eight samples, wet or dry weather), with collection of about five additional samples during this period targeted at rainfall-runoff events (wet weather). For these purposes, wet-weather samples are generally defined as samples collected when streamflow is affected by surface runoff, which varies among sites; as a practical matter, quantitative criteria to identify wet-weather periods (for example, at least 0.5 in. of rain within 2 days; Andrea Rex, Massachusetts Water Resources Authority, oral commun., 2000) and dry-weather periods (for example, no rain for 3 days) probably would be needed to direct the sampling program. In first-order streams, where contact recreation is less likely, monthly bacteria sampling (6 samples) is proposed during this period. It should be noted that even this frequent sampling for bacteria is not likely adequate for decisions on swimming safety at specific locations and times; rather, it is intended to determine general conditions for the CWA.

Nutrients, nitrogen and phosphorus species, contribute to eutrophication (excessive plant and algal growth) in water bodies. Water-quality standards for nutrients are listed as "site-specific criteria to control eutrophication" for aquatic life and recreational uses, rather than as numerical criteria (table 2). Obvious impairment of water bodies from eutrophication generally occurs during summer months, and is likely to occur in lakes and larger, slower-moving stream reaches. Thus, it is proposed that sampling for nutrients occur about monthly from March to mid-October in third-, fourth-, and fifth-order streams with bacteria sampling. Because nutrient concentrations vary with input from stormwater flows, it might be necessary that some of these samples be taken with the wet-weather bacteria samples. Tributaries contributing to large 
lakes, where eutrophication may be of special concern, also could be sampled, regardless of the streamsegment order. Nutrient sampling is proposed once per assessment for lakes, in spring, as a general indicator of lake trophic status. Periphyton community analysis is a response variable for nutrients that integrates over time the effects of variable nutrient concentrations. Periphyton or phytoplankton analysis is proposed for larger order streams, once per assessment; phytoplankton analysis also could be considered for some or all lakes, but is not proposed for the current program.

Several parameters are proposed for sampling only once per assessment on high-order streams and lakes (table 6). High-order streams are more likely to receive and accumulate toxic chemicals, and thus are appropriate for toxicity testing of sediment for the aquatic life use. Sampling for chlorine and other specific toxics chemicals is not proposed (except for ammonia, which is sampled with nutrients), because the occurrence of these contaminants is dependent on specific types of point-source discharges. Sedimentchemistry is most appropriate in depositional areas in streams, that is, in impounded areas of high-order stream segments and behind dams. Thus, the number of sediment-chemistry sampling sites would be less than the total number of high-order stream segments and would be determined for each basin. Sediment chemistry in smaller streams could be assumed satisfactory unless information about specific point-discharges suggests otherwise. Streams that might support the fish consumption use also are appropriate for fish tissue sampling. For the purposes of this design, fish tissue sampling is proposed for third-, fourth-, and fifth-order streams but also could occur in some smaller streams. Detailed sampling parameters, in terms of fish species and contaminants, would be determined on a site-specific basis.

Water-quality and public-health standards for suspended solids, turbidity, and transparency address aquatic life use, primary contact recreation, and aesthetics. Suspended solids is proposed for monthly and wet-weather measurement with bacteria sampling, because suspended solids vary with flow and may indicate sediment-borne contaminants; turbidity is included with field parameters. Secchi-disk transparency, an inexpensive measurement, could be measured in higher-order streams where appropriate with other field measurements. However, Secchi-disk depth can be highly variable, reflecting phytoplankton population dynamics. For lakes, where Secchi disk is used as a primary indicator of trophic status, semimonthly measurement is proposed from mid-March to mid-October (table 6). Trophic status as indicated by Secchi disk can be used to assess the aquatic life use.

Chlorophyll-a sampling and macrophyte cover measurements are proposed for lakes in addition to the frequent Secchi-disk measurements. Chlorophyll-a concentration is another indicator of trophic status and is proposed for semi-monthly sampling with Secchi disk. Macrophyte mapping is proposed for lakes once per assessment, in mid- to late summer. Macrophyte cover would be used to assess the recreational uses as well as the aquatic life use.

Finally, benthic macroinvertebrates, substrate parameters, and other habitat measures provide an integrated assessment of water-quality conditions and address narrative standards for aquatic life use. The parameters referred to here are determined using Rapid Bioassessment Protocols (RBP II or III) as defined by DEP (Commonwealth of Massachusetts, 1997). It is proposed that macroinvertebrates be monitored once per assessment, during the critical period for these biological communities, in all wadeable stream segments.

\section{Resource Requirements}

In quantifying resource requirements, the sampling-site density along large streams was reduced, based on the assumption that further review of the stream segmentation results would eliminate some segment boundaries along these streams, as discussed previously. Sampling site density was reduced to one-half the number of stream segments for fourth- and fifth-order streams (table 7), effectively yielding an average stream length per sample of $1 \mathrm{mi}$. Fourth- and fifth-order streams in the Neponset Basin flow through wetland areas with many small tributaries, some of which would likely be identified on further review as having a low potential to affect mainstem water quality; some segments also would be eliminated from sampling because of access problems. Sampling-site density along third-order streams was reduced by one-third (table 7). Most thirdorder streams were segmented at substantial tributaries; however, some third-order streams also flow through wetlands and further review would likely eliminate some segment boundaries in these areas. Sampling sites along first- and second-order streams were not reduced, because in most cases a first- or secondorder stream is represented by only one segment. 
Table 6. Sampling parameters and frequency for an exhaustive approach to Tier I monitoring in the Neponset Basin, Massachusetts

\begin{tabular}{|c|c|c|c|c|c|}
\hline \multirow[b]{2}{*}{ Water body } & \multicolumn{5}{|c|}{ Sampling parameters } \\
\hline & $\begin{array}{c}\text { Field } \\
\text { parameters }\end{array}$ & $\begin{array}{l}\text { Bacteria and } \\
\text { suspended } \\
\text { solids }\end{array}$ & Nutrients & Macroinvertebrates & $\begin{array}{l}\text { Periphyton } \\
\text { or } \\
\text { phytoplankton }\end{array}$ \\
\hline STREAMS & & -- & & & \\
\hline First order.............. & $\begin{array}{l}\text { monthly, March- } \\
\text { October }\end{array}$ & $\begin{array}{l}\text { monthly, March- } \\
\text { October }\end{array}$ & -- & once per assessment & -- \\
\hline Second order ........ & $\begin{array}{l}\text { monthly, March- } \\
\text { October; plus } 5 \\
\text { wet weather }\end{array}$ & $\begin{array}{l}\text { monthly, March- } \\
\text { October; plus } 5 \\
\text { wet weather }\end{array}$ & -- & once per assessment & -- \\
\hline Third order ........... & $\begin{array}{l}\text { monthly, March- } \\
\text { October plus } 5 \\
\text { wet weather }\end{array}$ & $\begin{array}{l}\text { monthly, March- } \\
\text { October; plus } 5 \\
\text { wet weather }\end{array}$ & $\begin{array}{l}8 \text { samples, } \\
\text { March-October }\end{array}$ & once per assessment & once per assessment \\
\hline Fourth order ......... & $\begin{array}{l}\text { monthly, March- } \\
\text { October plus } 5 \\
\text { wet weather }\end{array}$ & $\begin{array}{l}\text { monthly, March- } \\
\text { October; plus } 5 \\
\text { wet weather }\end{array}$ & $\begin{array}{l}8 \text { samples, } \\
\text { March-October }\end{array}$ & once per assessment ${ }^{1}$ & once per assessment $^{1}$ \\
\hline Fifth order ............ & $\begin{array}{l}\text { monthly, March- } \\
\text { October plus } 5 \\
\text { wet weather }\end{array}$ & $\begin{array}{l}\text { monthly, March- } \\
\text { October; plus } 5 \\
\text { wet weather }\end{array}$ & $\begin{array}{l}8 \text { samples, } \\
\text { March-October }\end{array}$ & once per assessment ${ }^{1}$ & once per assessment ${ }^{1}$ \\
\hline LAKES ..................... & $\begin{array}{l}\text { spring, midsummer, } \\
\text { and fall }\end{array}$ & -- & $\begin{array}{l}\text { once per assessment, } \\
\text { spring }\end{array}$ & -- & -- \\
\hline \multirow{2}{*}{ Water body } & \multicolumn{5}{|c|}{ Sampling parameters } \\
\hline & $\begin{array}{l}\text { Sediment chemistry } \\
\text { and toxicity }\end{array}$ & $\begin{array}{l}\text { Fish } \\
\text { tissue }\end{array}$ & Macrophytes & Transparency & Chlorophyll-a \\
\hline \multicolumn{6}{|l|}{ STREAMS } \\
\hline First order............. & -- & -- & -- & -- & -- \\
\hline Second order ........ & -- & -- & -- & -- & -- \\
\hline Third order ........... & once per assessment & once per assessment & -- & -- & -- \\
\hline Fourth order ......... & once per assessment & once per assessment & once per assessment $^{2}$ & same as bacteria ${ }^{2}$ & -- \\
\hline Fifth order ............ & once per assessment & once per assessment & once per assessment $^{2}$ & same as bacteria ${ }^{2}$ & -- \\
\hline LAKES ..................... & -- & -- & $\begin{array}{l}\text { once per assessment; } \\
\text { midsummer }\end{array}$ & $\begin{array}{l}\text { semi-monthly, } \\
\text { March-October }\end{array}$ & $\begin{array}{l}\text { semi-monthly, } \\
\text { March-October }\end{array}$ \\
\hline
\end{tabular}

\footnotetext{
${ }^{1}$ Wadeable segments only

${ }^{2}$ Sampling for transparency and macrophytes where appropriate
} 
Table 7. Resource requirements for an exhaustive approach to Tier I monitoring in the Neponset Basin, Massachusetts

[Number of visits per location: One visit may include multiple sampling teams. Type of sampling: B, fecal coliform bacteria; C, chlorophyll-a; F, field parmeters; Ft, fish tissue; N, nutrients; Mp, macrophytes; Mv, macroinvertebrates; P, periphyton or phytoplankton; Ss, suspended solids; Sx, sediment chemistry and toxicity; T, transparency; --, not applicable; not all sample types are collected at each site visit.]

\begin{tabular}{|c|c|c|c|c|c|c|c|c|}
\hline \multirow[b]{2}{*}{ Water body } & & \multicolumn{7}{|c|}{ Sample collection } \\
\hline & & $\begin{array}{c}\text { Number of } \\
\text { sampling location }\end{array}$ & \multicolumn{2}{|c|}{$\begin{array}{l}\text { Number of visits } \\
\text { per location }\end{array}$} & $\begin{array}{l}\text { Total number } \\
\text { of visits }\end{array}$ & \multicolumn{3}{|c|}{ Type of sampling } \\
\hline \multicolumn{9}{|l|}{ STREAMS } \\
\hline \multicolumn{2}{|c|}{ 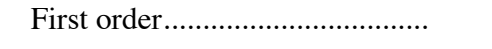 } & 158 & \multicolumn{2}{|l|}{6} & 948 & \multicolumn{3}{|l|}{$\mathrm{F}, \mathrm{B}, \mathrm{Mv}$} \\
\hline \multicolumn{2}{|c|}{ 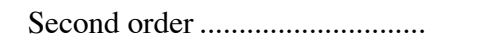 } & 58 & \multicolumn{2}{|l|}{13} & 754 & \multicolumn{3}{|l|}{$\mathrm{F}, \mathrm{B}, \mathrm{Mv}$} \\
\hline \multicolumn{2}{|c|}{ 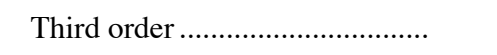 } & 32 & \multicolumn{2}{|l|}{13} & 416 & \multicolumn{3}{|c|}{$\mathrm{F}, \mathrm{B}, \mathrm{N}, \mathrm{Ss}, \mathrm{Mv}, \mathrm{P}, \mathrm{Sx}^{1}, \mathrm{Ft}$} \\
\hline \multicolumn{2}{|c|}{ 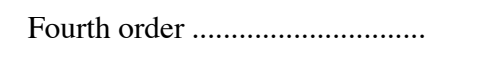 } & 13 & \multicolumn{2}{|l|}{13} & 169 & \multicolumn{3}{|c|}{$\mathrm{F}, \mathrm{B}, \mathrm{N}, \mathrm{Ss}, \mathrm{Mv}, \mathrm{P}, \mathrm{Sx}^{1}, \mathrm{Ft}, \mathrm{Mp}^{2}, \mathrm{~T}^{2}$} \\
\hline \multicolumn{2}{|c|}{ 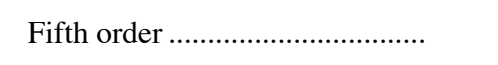 } & 12 & \multicolumn{2}{|l|}{13} & 165 & \multicolumn{3}{|c|}{$\mathrm{F}, \mathrm{B}, \mathrm{N}, \mathrm{Ss}, \mathrm{Mv}, \mathrm{P}, \mathrm{Sx}^{1}, \mathrm{Ft}, \mathrm{Mp}^{2}, \mathrm{~T}^{2}$} \\
\hline \multicolumn{2}{|c|}{ LAKES } & 46 & \multicolumn{2}{|l|}{14} & 644 & \multicolumn{3}{|l|}{$\mathrm{F}, \mathrm{N}, \mathrm{Mp}, \mathrm{T}, \mathrm{C}$} \\
\hline \multicolumn{2}{|c|}{ TOTAL } & 319 & \multicolumn{2}{|l|}{--} & 3,096 & \multicolumn{3}{|c|}{--} \\
\hline \multirow[b]{2}{*}{ Water body } & \multicolumn{8}{|c|}{ Laboratory analyses } \\
\hline & Bacteria & Nutrients & $\begin{array}{l}\text { Suspended } \\
\text { solids }\end{array}$ & $\begin{array}{c}\text { Macro- } \\
\text { inverte- } \\
\text { brates }\end{array}$ & $\begin{array}{c}\text { Periphyton } \\
\text { or phtyo- } \\
\text { plankton }\end{array}$ & $\begin{array}{c}\text { Sediment } \\
\text { chemistry } \\
\text { and toxicity }\end{array}$ & $\begin{array}{l}\text { Fish } \\
\text { tissue }\end{array}$ & $\begin{array}{l}\text { Chloro- } \\
\text { phyll-a }\end{array}$ \\
\hline \multicolumn{9}{|l|}{ STREAMS } \\
\hline First order.......................... & 948 & -- & -- & 158 & -- & -- & -- & -- \\
\hline Second order ...................... & 754 & -- & -- & 58 & -- & -- & -- & -- \\
\hline Third order ......................... & 416 & 256 & 416 & 32 & 32 & 32 & 14 & -- \\
\hline Fourth order ...................... & 169 & 104 & 169 & 7 & 7 & 13 & 5 & -- \\
\hline Fifth order ........................... & 156 & 96 & 156 & 6 & 6 & 12 & 6 & -- \\
\hline 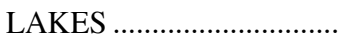 & -- & 46 & -- & -- & -- & -- & -- & 644 \\
\hline 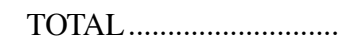 & 2,443 & 502 & 741 & 261 & 45 & 57 & 25 & 644 \\
\hline
\end{tabular}

These modifications, although arbitrary, were used to allow for a more realistic estimation of the resources required for an exhaustive sampling of water-resources in the basin. However, although yielding a more reasonable sampling density, the modifications also introduce subjectivity into the site-selection scheme and could be considered to compromise the exhaustive assessment.

Resource requirements for the exhaustive approach were defined in terms of the personnel needed for sample collection and of the laboratory analyses needed (table 7). The total number of sampling sites was 273 for streams and 46 for lakes, for a total of 2,423 site visits. Sampling sites for fish tissue, proposed for higher-order streams, was reduced to a density of one sample per $2 \mathrm{mi}$ of stream. Personnel requirements for sample collection were determined using estimates from DEP/DWM as follows: field parameters, bacteria, nutrients, and suspended sediment (in streams), five sites per day for two people; macroinvertebrates, two sites per day for three people plus one laboratory day per sample; periphyton or phytoplankton, four sites per day for three people plus one laboratory day per field day; sediment chemistry, two sites per day for two people; fish tissue, one site per day for two people plus one laboratory day per sample; 
and lakes, one to two days per site for two people (A.S. Johnson, Massachusetts Department of Environmental Protection, oral commun., 1999 and 2000). The personnel estimates for stream sampling assume that isokinetic depth- and width-integrated samples would not be taken. According to these estimates, 2,661 personneldays (12.1 full-time equivalent employees, or FTEs) would be required for sample collection alone. Note that most of these activities would occur between March and October, so that the number of people conducting sampling in those months would be greater than the FTE estimates indicate. The number of laboratory analysis range from 25 for fish tissue to 2,443 for bacteria, for a total of 4,718 analyses (table 7).

Resources (primarily personnel) also would be needed for final site selection, obtaining permissions from private landowners, field-work preparation, data management, and data analysis. Note that these resource estimates would have been greater by about one-third without the reductions in sampling density for large streams described previously.

\section{Analysis of the 1994 Neponset Water-Resource Assessment}

In the early 1990s, the DEP/DEM led a group of agencies within the Massachusetts EOEA in an indepth assessment of water resources in the Neponset River Basin (1994 Neponset assessment; Kennedy and others, 1995). This work was conducted as a pilot for the MWI and involved environmental monitoring as well as review of discharge and water-withdrawal permits, water use, and streamflow in the basin. Types of monitoring included physical and chemical monitoring, bacteria sampling, sampling for sediment chemistry and toxicity, and biological monitoring. About 40 to 50 sampling sites were monitored with about 250 site visits. Objectives for the monitoring program were (1) to provide information on current water-quality conditions in the basin and toxic contaminants at specific locations, (2) to identify sources of bacterial contamination, (3) to assess the biological integrity of the Neponset River and specific tributaries, (4) to identify priority non-point-source pollution sources, and (5) to conduct an overall assessment and determine the use-support status with respect to State water-quality standards of water resources in the basin (Kennedy and others, 1995, p. 1-2 to 1-3). Thus, the 1994 Neponset assessment was intended to address multiple information needs, only one of which was the use-support assessment of the CWA. In addition, the assessment of existing conditions and use support was not intended to be comprehensive, in the sense of providing information on 100 percent of the water bodies in the basin. However, a comparison of the monitoring program and results of the 1994 assessment with the goals and requirements of a comprehensive assessment provides useful information for the design of a monitoring program within constraints of limited resources and multiple information needs.

About one-half of the total number of perennial stream miles in the Neponset basin were reported as assessed for overall use support in the 1994 study (fig. 5; Kennedy and others, 1995). One-half of the stream miles also were assessed for specific uses of contact recreation (primary and secondary) and aquatic life based on field water-quality parameters. Smaller fractions of stream miles were assessed for aquatic life use based on sediment chemistry and biology, for fish consumption, and for aesthetics. These values of stream miles for assessed reaches were determined by identifying the reaches in the DEP SARIS inventory (Halliwell and others, 1982) and summing the lengths of their component stream segments (where segment lengths were determined as described in the appendix; these calculated lengths generally were similar to lengths reported in Halliwell and others, 1982). ${ }^{2}$

Streams reported as assessed in the 1994 study corresponded to the mainstem Neponset River, East Branch Neponset River, and their major tributaries. Thus, all fourth- and fifth-order stream miles and most (86 percent) third-order stream miles in the basin were assessed for recreational and aquatic life (field waterquality parameters) uses; overall use support also was considered assessed for these stream miles. Most (more than 90 percent) fourth- and fifth-order streams also were assessed for the other designated uses (except for

\footnotetext{
${ }^{2}$ An alternative approach to calculating the numbers of assessed stream miles would have been to use the lengths of the individual stream segments (as delineated in the present study) on which the 1994 sites were located, rather than the lengths of the entire SARISinventoried stream. That approach would have yielded lower values for assessed stream miles; however, it also would have imposed the definitions proposed in the present study, of how to delineate stream reaches with uniform water quality, upon the 1994 study and was not considered appropriate.
} 


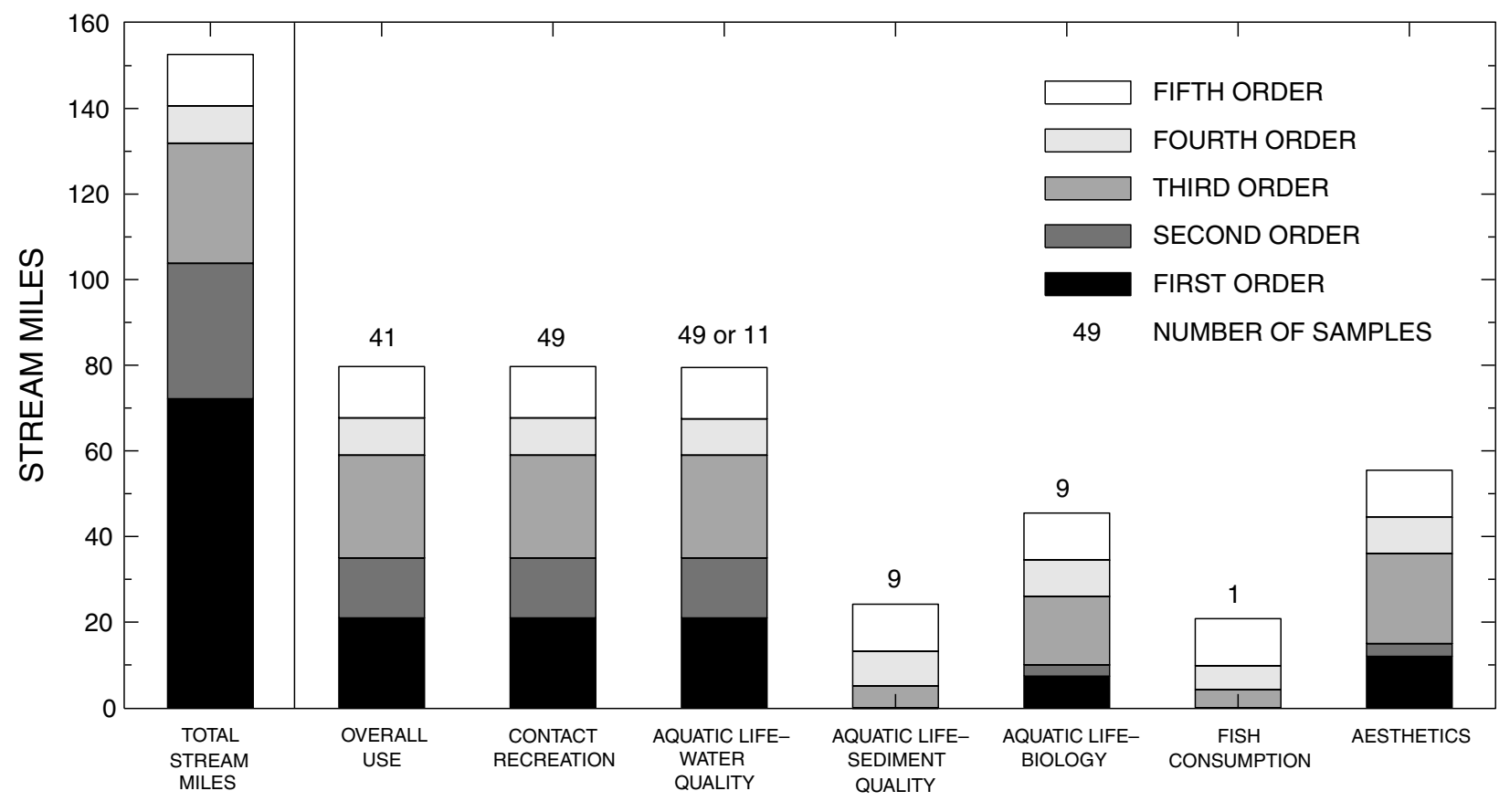

DESIGNATED USE

Figure 5. Total perennial stream miles in the Neponset Basin and assessed miles by stream order and designated use from the 1994 Neponset water-resource assessment. Numbers above bars are the number of samples on which the assessments were based. Numbers for aquatic-life use based on water quality represent samples for dissolved oxygen and other field parameters (49 samples) or chemical concentrations (11 samples). No information was available on sample number for the aesthetics use. Data from Kennedy and others (1995).

fish consumption); assessed fractions of third-order streams varied by use ( 15 to 75 percent). Less than onehalf of the second-order stream miles and less than one-third of the first-order stream miles were assessed for any use. The unassessed small streams were primarily tributaries to the major named tributaries and mainstem rivers in the basin. Because these streams are numerous, their exclusion from the assessed population results in a large fraction (50 percent) of the stream miles in the basin unevaluated for support of their designated uses. Moreover, the site-selection procedures, which appear to have followed a targeted approach where specific reaches were identified for sampling based on known problems or other reasons, makes it difficult to extrapolate conditions in the assessed streams to the remaining streams.

The sampling density of the 1994 assessment for streams was less than that of the proposed exhaustive approach both temporally and spatially. The sampling density averaged $2 \mathrm{mi}$ per sample for the recreational uses and aquatic life use based on field parameters; 3 , 5 , and $7 \mathrm{mi}$ per sample for aquatic life use, based on sediment chemistry, biology, and water chemistry, respectively; and $21 \mathrm{mi}$ per sample for fish consumption (fig. 5). Single samples generally were used to assess the entire lengths of major tributaries, the East Branch Neponset River, and the mainstem Neponset River for aquatic life use in terms of sediment quality or water chemistry. Use support for contact recreation and for aquatic life use in terms of dissolved oxygen and other field parameters was determined from samples from about three dates per site in the summer period, one of which was 2 days after significant precipitation (Kennedy and others, 1995); additional dissolved-oxygen samples documenting daily low values were used for some sites. Thus, temporal variability of bacteria and dissolved oxygen during wet weather may not have been well characterized at some sites.

Thirty-five lakes were wholly or partially assessed for three designated uses in the 1994 assessment. Monitoring consisted of one site visit per lake to determine macrophyte cover, the presence of nonnative or nuisance vegetation, and transparency (Secchi disk or visual estimate), observed from one or more 
sampling points. The use support assessment for secondary contact recreation was based on macrophyte cover. Primary contact recreation and aquatic life uses were assessed in a limited way, using macrophyte cover and transparency, rather than bacteria or chemical data, which were not collected (Kennedy and others, 1995). Where macrophyte cover was substantial, lakes were reported as impaired for aquatic life and recreational uses; otherwise lakes were not assessed for these uses. Using this approach, 26 and 15 lakes were reported as impaired for the primary contact recreation and aquatic life uses, respectively. Lake acres supporting these uses could not be identified. The fish consumption use was assessed for one lake only. Thus, a minimal amount of data was available for the use-support determinations for lakes. Criteria for including lakes in the assessment were not reported. The 35 lakes assessed for secondary contact recreation represented about one-half of the PALIS-coded lakes (Ackerman and others, 1984; Ackerman, 1989), typically including all lakes greater than 10 acres but some of the smaller lakes ( 3 to 5 acres) as well. The 35 lakes accounted for 76 percent of the total lake acres and about 90 percent of the acres of significant lakes (lakes larger than 5 acres).

\section{Combined Probabilistic- Deterministic Approach}

Investigation of the exhaustive approach and analysis of the MWI pilot monitoring program demonstrates the resource-based problems posed by the many small streams in a basin and illustrates the difficulties in determining sampling densities for Tier I monitoring. For small streams, a probabilistic approach would be advantageous, in that this approach would provide some information about all small streams without the prohibitive resource investment required to sample all of them. The information generated by a probabilistic monitoring program could be sufficient to meet the CWA assessment and reporting requirements for all streams in a basin (S. Paulsen, U.S. Environmental Protection Agency, National Health and Environmental Effects Research Laboratory, oral commun., 1999). However, the DEP and MWI teams require information about water-quality conditions in all mainstem rivers and major tributaries in a basin, for objectives of the Clean Water Act and other purposes beyond that of the 305(b) assessment of use-support status. Specifically, information is needed to identify impaired reaches, to determine causes and sources of impairment, and to target control strategies (A.S. Johnson, Massachusetts Department of Environmental Protection, written commun., 1999). Thus, a monitoring program is described in this section that combines probabilistic sampling for small streams with deterministic sampling on large streams that is intended to meet Tier I objectives while also providing information to meet other important water-quality needs in Massachusetts. For lakes, both probabilistic and deterministic programs are discussed. Resource limitations also are addressed by reducing the number of sampling parameters, such that data are collected to evaluate only some, not all, of the applicable numeric and narrative State water-quality standards at some sites. Sampling-density issues (spatial density and frequency) remain a problem, and are discussed further in this section. The monitoring approach described in this section is intended to be implemented in conjunction with the MWI initiative, such that sampling would be conducted at 5-year intervals on a rotating basis in each of the 27 major river basins.

\section{Sampling Sites, Parameters, Frequency, and Resource Requirements for Streams}

\section{Probabilistic Sampling Program}

Probabilistic sampling is proposed for first-, second-, and third-order perennial streams in each basin. In the Neponset Basin, first- and some secondorder streams are primarily headwater streams; thirdorder and second-order streams are the upper reaches of, and major tributaries to, the mainstem Neponset and East Branch Neponset Rivers (fig. 4). These streams are proposed for probabilistic monitoring because of their large number and because, as smaller, headwater streams, many may be less likely to be impaired. Multiple approaches are possible for site selection and sampling parameters and frequency on these streams. Previous and ongoing programs in other States are reviewed to provide background information and discuss advantages and disadvantages of different approaches to probabilistic monitoring.

Probabilistic sampling programs for statewide biomonitoring surveys were conducted in Maryland and Delaware in the early 1990s. In the Maryland assessment, sampling sites were selected on first-, second-, and third-order streams by dividing all 
wadeable streams (impounded, nonwadeable reaches were excluded from the assessment) into 246-foot (75-meter) segments in a digital data layer and randomly selecting segments for sampling (Roth, 1997a, 1997b). Eighteen basins in three regions were sampled over a 3-year period ( 2 basins per region per year), with the number of sampling sites distributed proportionately according to the stream miles per basin and stream order. One basin in each region was sampled in two consecutive years to measure betweenyear variability (Roth and others, 1997b). In the first year of the program (1995), 284 sites were sampled for biological, chemical, and physical parameters. Data from this program were successfully analyzed to calculate percentages of stream miles that were biologically degraded, acidic, or had poor habitat conditions as well as to relate these estimates to land use (Roth and others, 1997b). Disadvantages of the approach were problems in its field implementation, including the inability to access or sample some of the selected segments or difficulty in obtaining permission for sampling from private land owners (Maryland Department of Natural Resources, oral commun., 1999).

In the Delaware assessment for 305(b) reporting in 1993, sites were randomly selected from about 3,300 potential sampling locations on all nontidal streams in the State; the potential sampling points were at the intersections of streams and roads and were identified in GIS (J.R. Maxted, Delaware Department of Natural Resources and Environmental Control, Dover, Del., written commun., 1998, 2000). Sampling sites were distributed among 35 major watersheds according to the distribution of stream miles, to avoid bias associated with the uneven distribution of roads in the State. This approach had an advantage in that it was not necessary to obtain permissions from private land owners and that sites were easy to access. However, subsequent analysis determined that sampling at road crossings was likely to provide a biased estimate (worse than actual) of water-quality conditions in the assessment area (J.R. Maxted, written commun., 2000).

Probabilistic monitoring programs also have been initiated in several other States. In New Jersey, 40 random sampling sites, used for a statewide status assessment, are part of a larger ambient monitoring program that includes 6 background, 20 watershed integrator, 40 land-use indicator, and 10 additional targeted sampling sites per year (Jacob Gibs, U.S. Geological Survey, West Trenton, N.J., written commun., 1998). Sites are randomly selected from an existing network of biomonitoring sites for repeated (4 times) sampling each year for physical, chemical, and sanitary microbiological indicator organism (5 times in 30 days) monitoring; these sites are distributed geographically so that 2 sites are chosen in each of 20 water-management areas in the State.

In Indiana, Kentucky, and South Carolina, probabilistic monitoring programs for 305(b) assessments are underway that have been designed in collaboration with the USEPA Regional Environmental Monitoring and Assessment Program (R-EMAP; A.R. Olsen, U.S. Environmental Protection Agency, Corvallis, Oreg., oral commun., 2000). The programs are designed on 5-year cycles. Points are randomly selected along the USEPA NHD river reach files (1:100,000 scale) as sampling sites. In Kentucky and Indiana, probabilistic monitoring on all streams in the State is being implemented as part of 5-year, rotatingbasin plans similar to the MWI (Kentucky Division of Water, 1997; A. Garceau, Indiana Department of Environmental Management, personal commun., 2000). In Kentucky, 1 to 3 of 12 major basins in the State are monitored during the assessment phases of the program. A current monitoring plan includes 30 to 35 probabilistic sites in each of 2 major basins, which are sampled once for macroinvertebrates and habitat and are used to assess the aquatic life use (Wood and others, 1999). These sites are supplemented with sampling of 14 long-term fixed sites on large rivers (physical, chemical, and biological monitoring) and about 250 targeted biomonitoring sites on nearly all fourth-order streams in the 2 major basins ${ }^{3}$. In the Indiana program, 40 to 64 sites have been sampled in about 2 basins per year for the past 5 years (A. Garceau, Indiana Department of Environmental Management, personal commun., 2000). Sites are sampled three times per year for physical and chemical parameters and once for biological parameters. The program requires four FTEs and two summer interns each year. A pre-survey is conducted in early spring to locate the preselected sites in the field and obtain

\footnotetext{
${ }^{3}$ Multiple groups are responsible for sample collection from this large number of sites, including the Kentucky Division of Water, Kentucky Fish and Wildlife, a university, and several Federal agencies (Wood and others, 1999).
} 
permissions. The probabilistic sampling is part of a larger program that includes targeted sites for indicator bacteria (about 150 sites, sampled 5 times in a 30-day period) and pesticides (about 23 sites, sampled once) and fixed stations for physical and chemical parameters (160 sites, sampled monthly; A. Garceau, Indiana Department of Environmental Management, personal commun., 2000). In the South Carolina programs, about 30 randomly selected sites distributed across the State are sampled each year, such that monitoring results from about 150 sites are available for a statewide assessment after 5 years. (A.R. Olsen, U.S. Environmental Protection Agency, Corvallis, Oreg., oral commun., 2000). Advantages of the South Carolina program are that estimates of water-quality conditions for the entire state (although of lower precision than the 5-year estimate) can be made each year, and the effects of year-to-year climate variations are minimized. In the Kentucky and Indiana programs, statewide estimates are made by combining basin estimates from a 5-year cycle; potential yearly climate variations could introduce bias into these statewide assessments. On the other hand, estimate of water-quality conditions and impaired stream miles can be made at the basin as well as the statewide scale from these programs, which are not possible with the South Carolina approach as described.

The probabilistic-based monitoring proposed for Massachusetts is similar to the more recent State programs in that it would consist of a relatively small number of sites and be part of a larger monitoring program. Procedures are needed for new site selection, as in most of the programs described. Potential site selection approaches based on these experiences include: (1) systematically dividing the streams into segments defined by physical features (tributary confluences, lakes, and point-source discharges) that potentially alter water quality, as described in the Neponset analysis, and randomly selecting segments for sampling; (2) dividing the streams into short, uniform reaches and randomly selecting reaches for sampling as in the Maryland program; and (3) randomly selecting point sampling locations along the stream network, as in the South Carolina and Kentucky programs; the Delaware approach of selecting sites from road crossings is not considered because of its potential bias. Approaches (2) and (3) are likely to be very similar in practice, depending on the reach length in (2) and the flexibility allowed to the sampling team to search within some buffer distance around the precise point location chosen in (3) for a suitable sampling site. Approach (1) differs from these in that every stream segment, rather than every point on the stream segment, has an equal chance of being selected for sampling in this approach. It is based on an assumption that the segmentation scheme provides the best available criteria for predefining reaches with relatively uniform water quality. This assumption is supported by the use of physical features representing potential contaminant inputs (tributary confluences and point sources) and changing flow conditions (lakes) to define stream segments. Approach (1) has the advantage that sampling sites immediately downstream of these features can be avoided, thereby maximizing the length of stream characterized by each sample. In addition, problems of field access and permissions may be reduced, because there are likely to be multiple points along a segment that are suitable for sampling from which a precise sampling point could be chosen.

A problem with approach (1), however, is that the assumption of uniform water quality within segments may not always be valid. For example, changing land uses and variable contaminant inputs from nonpoint sources along a reach are not well represented in a stream-segmentation scheme based on tributaries, lakes, and point sources. The alternative approach of (2) and (3), above, to randomly select points or short reaches along the continuous stream network, makes no assumptions about the length of stream that the sampling point represents. While necessary for an exhaustive or targeted approach, such assumptions are not needed to estimate the proportion of stream miles in an area that meet or fail to meet water-quality standards with a probabilistic approach, because it is not necessary with the probabilistic approach to relate monitoring results from a point sampling location to any particular length of stream. Thus, a site selection scheme that does not predefine stream reaches, thereby avoiding assumptions about water quality, might be most appropriate for the Tier I probabilistic monitoring proposed for small streams in Massachusetts.

The USEPA R-EMAP program has developed several procedures for site selection using digital hydrographic data for a probabilistic monitoring program. Alternative designs select sites for a simple random sample, a stratified random sample, an unequal probability sample, or a spatially balanced sample (A.R. Olsen, U.S. Environmental Protection Agency, Corvallis, Oreg., written commun., 2000). A simple random sample, which has no weighting or other 
discrimination among potential sites, is easiest to implement and analyze but provides the least precise estimates, because it incorporates no knowledge of existing conditions. A stratified random sample allows for estimates of conditions within subpopulations of the target population, which may be defined based on supplementary knowledge, such that estimates for individual subpopulations are more precise than the overall estimate; however, more samples are needed than in the simple random sample, because the same number of samples are needed for each strata as for the entire total simple random program. In an unequal probability sample, site selection is weighted based on defined categories (such as stream order or geographic area) such that streams from some categories have a greater or lesser likelihood of being selected than would otherwise result from their number. Results from an unequal probability sample are analyzed using weighting factors that adjust for the numerical proportion of each category relative to the total population. Finally, in a spatially distributed or "balanced" sample, the spatial distribution of sampling sites and the target population are similar, which results in a more precise estimate; thus, sampling sites would be distributed in a basin in the same way as the streams are distributed, and "clumping" of sites would be avoided.

Because the objective of the Massachusetts monitoring program is an unbiased estimate of conditions in small streams in the State, a simple (unweighted), spatially distributed design might be most appropriate for the proposed probabilistic sampling. A simple random sample is likely to be dominated by samples on first-order streams. An unequal probability sample, designed so that all stream orders were equally likely to be sampled, might be used, and could be considered to provide a more unbiased estimate of streams in terms of water volume in an area (assuming that higher-order streams represent more flow); alternatively, such a weighted estimate might be considered more biased because the larger streams in the population, which might be more likely to be impaired, would be oversampled in terms of stream miles relative to small streams. These potentially ambiguous interpretations suggest that a simple random sample might be preferable. Use of a spatially distributed design is suggested because of the increased precision of this approach (A. Olsen, U.S. Environmental Protection Agency, Corvallis, Oreg., written commun., 2000). Collaboration with USEPA R-EMAP might be an efficient and effective way to select sites for the probabilistic monitoring program in Massachusetts. However, it is proposed that the MassGIS hydrographic data $(1: 25,000)$ be used for site selection rather than the NHD (or RF3, at 1:100,000 scale), because the MassGIS data provide the most upto-date, accurate, and widely used digital hydrography for Massachusetts. Use of these data will likely minimize the problems commonly encountered with field implementation of probabilistic sampling programs, such as the preselection of sites that don't exist or are otherwise not suitable for sampling.

The number of sampling sites to include in the program depends on the objectives, the level of confidence and desired precision for the status estimates, and the resources available for the program. The status estimates yielded by the probabilistic sampling are in terms of the number of sites among all sampled sites meeting water-quality standards (or some other definition of status). This proportion is taken to represent the proportion of stream miles in the sampled area meeting water-quality standards. If program objectives require status estimates for each individual basin as well as for the State as a whole, then many more samples will be needed. A design to meet these objectives is essentially a stratified random design with strata defined by the basin areas, such as in the Kentucky and Indiana programs described previously. The precision of the status estimate is represented as a confidence interval, which is a range of proportion values (as percents) that will include the true value with a specified probability. A more precise estimate is represented by a narrower range of values, or smaller confidence interval. The probability that the interval in fact contains the true value of the proportion is its confidence level. For example, a 90-percent confidence interval around the proportion estimate includes the true value on average 90 percent of the time, whereas a 95-percent confidence interval includes the true value 95 percent of the time (Helsel and Hirsch, 1992). The confidence interval can be calculated in advance of sampling from the number of sampling sites and the value of the proportion (for example, of sites or stream miles) being estimated (a proportion of 0.5 can be assumed to yield a conservative precision estimate; A. Olsen, U.S. Environmental Protection Agency, Corvallis, Oreg., written commun., 2000). The equation is as follows (Schaeffer and McClave, 1982): 


$$
\frac{y}{n} \pm z_{\alpha / 2} \bullet \sqrt{\frac{p(1-p)}{n}}
$$

where

$\frac{y}{n}$ is the observed proportion of sites meeting

water-quality standards (or some other

definition of status)

$n$ is the number of sampling sites

$p$ is the true probability of observing a site that meets water-quality standards, which is estimated by $\frac{y}{n}$

$z_{\alpha / 2}$ is the area under the normal distribution curve for alpha $(\alpha)$ values equal to [ 1 - confidence level]; equal to 1.645 for a 90 -percent confidence level and 1.96 for a 95 -percent confidence level.

Increasing the number of sampling sites increases the precision (narrower confidence interval) for a given confidence level. Thus, confidence intervals (in percent) associated with an assumed proportion of 50 percent of streams in an area meeting water-quality standards would be \pm 16 percent for a sample size of 25 , \pm 12 percent for a sample size of 50 , and \pm 8 percent for a sample size of 100 , with a 90 -percent confidence level; with a 95-percent confidence level, the same sample sizes would result in estimates of $\pm 20, \pm 13$, and \pm 10 percent, respectively (A. Olsen, U.S. Environmental Protection Agency, Corvallis, Oreg., written commun., 2000; these values are based on a simple random sample). If the observed proportion of streams meeting water-quality standards were less or more than 50 percent, the calculated confidence intervals would be narrower. Thus, a range of sample sizes might be considered to provide adequate estimates of the proportion of stream miles in an area meeting water-quality standards. In most cases, resource limitations will ultimately decide the precise number of sampling sites used, once the program objectives have been defined. However, some sample sizes clearly would be too small to provide adequate status estimates. For example, a sample size of 10 would result in a confidence interval (precision) of \pm 26 percent for an estimate of 50 percent of streams meeting standards with a 90 -percent confidence level; in other words, it could be stated with a 90-percent probability of being true that somewhere between 24 to 76 percent of the stream miles in the sampled area met standards, based on this sample size.
This range might be considered too large to provide useful information for the question of whether the streams in the sampled area met their designated uses.

A Massachusetts program would likely be implemented in about five basins per year. Thus, a sample size of 30 to 50 sites per basin, yielding a 90-percent confidence-interval estimate of about \pm 15 to \pm 12 percent around a proportion of 50 percent, would require 150 to 250 sites statewide. This sampling density would support status estimates for individual basins, but may be too many sites to implement, given realistic resource limitations. On the other hand, a sample size of 30 to 50 sites statewide would likely be too small to provide individual status estimates for each basin. Moreover, the annual estimate based on these sampling sites would be applicable only to areas in the State within the sampled basins, considered jointly. A better approach might be to select 30 to 50 sites statewide each year, such as in the South Carolina program, with the potential for additional sites in the 5 assessment-year basins if better representation for those basins is desired. This alternative presents an opportunity for the use of volunteer monitors, coordinated through the MWI teams, to collect data at additional sites to monitor basins more densely where individual status estimates are desired. This would work best in basins where volunteer groups with relatively sophisticated monitoring capabilities and organization structures already exist. Careful planning and oversight of the volunteer program would likely be necessary to ensure data quality and comparability among basins and with DEP/DWM data. Clearly, decisions about sample sizes and implementation of the probabilistic approach require management-level input, and are likely to be based on considerations about the importance of Tier I probabilistic monitoring for 305(b) reporting relative to other aspects of a statewide monitoring program.

For the Massachusetts program, macroinvertebrate and bacteria (fecal coliform and E. coli) sampling are proposed for probabilistic sites on small streams (table 8). This will allow use-support status (that is, impaired or not impaired) to be determined for all small streams for aquatic life and contact recreational uses statewide and possibly per basin. Macroinvertebrate sampling is proposed once per assessment, and bacteria sampling is proposed monthly from March to mid-October (eight samples). Note that the status assessments for individual basins that incorporate 
Table 8. Sampling parameters and frequency for a combined probabilistic-deterministic approach to Tier I monitoring in the Neponset Basin, Massachusetts

[Monitoring approach: $\mathrm{D}$, deterministic; $\mathrm{P}$, probabilistic; --, not sampled]

\begin{tabular}{|c|c|c|c|c|c|c|}
\hline \multirow[b]{2}{*}{ Water body } & \multirow{2}{*}{$\begin{array}{l}\text { Monitor- } \\
\text { ing } \\
\text { approach }\end{array}$} & \multicolumn{5}{|c|}{ Sampling parameters } \\
\hline & & $\begin{array}{c}\text { Field } \\
\text { parameters }\end{array}$ & $\begin{array}{l}\text { Bacteria and } \\
\text { suspended } \\
\text { solids }\end{array}$ & Nutrients & $\begin{array}{c}\text { Macro- } \\
\text { invertebrates }\end{array}$ & $\begin{array}{l}\text { Periphyton or } \\
\text { phtyoplankton }\end{array}$ \\
\hline \multicolumn{7}{|l|}{ STREAMS } \\
\hline $\begin{array}{l}\text { First, second, and } \\
\text { third order ......... }\end{array}$ & $\mathrm{P}$ & $\begin{array}{l}\text { monthly, March- } \\
\text { October }\end{array}$ & $\begin{array}{l}\text { monthly, March- } \\
\text { October }\end{array}$ & -- & $\begin{array}{l}\text { once per } \\
\text { assessment }\end{array}$ & -- \\
\hline Third order ........... & $\mathrm{D}$ & $\begin{array}{c}\text { monthly, March- } \\
\text { October; plus } \\
5 \text { wet weather }\end{array}$ & $\begin{array}{c}\text { monthly, March- } \\
\text { October; plus } \\
5 \text { wet weather }\end{array}$ & $\begin{array}{c}8 \text { samples, } \\
\text { March- } \\
\text { October }\end{array}$ & $\begin{array}{l}\text { once per } \\
\text { assessment }\end{array}$ & $\begin{array}{l}\text { once per } \\
\text { assessment }\end{array}$ \\
\hline $\begin{array}{l}\text { Fourth and } \\
\text { fifth order .......... }\end{array}$ & $\mathrm{D}$ & $\begin{array}{c}\text { monthly, March- } \\
\text { October plus } \\
5 \text { wet weather }\end{array}$ & $\begin{array}{c}\text { monthly, March- } \\
\text { October; plus } \\
5 \text { wet weather }\end{array}$ & $\begin{array}{c}8 \text { samples, } \\
\text { March- } \\
\text { October }\end{array}$ & $\begin{array}{l}\text { once per } \\
\text { assessment }^{1}\end{array}$ & $\begin{array}{l}\text { once per } \\
\text { assessment }^{1}\end{array}$ \\
\hline LAKES ................... & $\mathrm{P}$ or $\mathrm{D}$ & $\begin{array}{l}\text { spring, mid-summer, } \\
\text { and fall }\end{array}$ & -- & \multicolumn{2}{|c|}{$\begin{array}{l}\text { once per assessment; } \\
\text { spring }\end{array}$} & -- \\
\hline & & \multicolumn{5}{|c|}{ Sampling parameters } \\
\hline Water body & $\begin{array}{c}\text { ing } \\
\text { approach }\end{array}$ & $\begin{array}{l}\text { Sediment } \\
\text { chemistry } \\
\text { and toxicity }\end{array}$ & $\begin{array}{l}\text { Fish } \\
\text { tissue }\end{array}$ & Macrophtyes & Transparency & Chlorophyll-a \\
\hline \multicolumn{7}{|l|}{ STREAMS } \\
\hline $\begin{array}{c}\text { First, second, and } \\
\text { third order ....... }\end{array}$ & $\mathrm{P}$ & -- & -- & -- & -- & -- \\
\hline Third order ........... & $\mathrm{D}$ & $\begin{array}{l}\text { once per } \\
\text { assessment }\end{array}$ & -- & -- & -- & -- \\
\hline $\begin{array}{l}\text { Fourth and fifth } \\
\text { order ............... }\end{array}$ & $\mathrm{D}$ & $\begin{array}{l}\text { once per } \\
\text { assessment }\end{array}$ & $\begin{array}{l}\text { once per } \\
\text { assessment }\end{array}$ & $\begin{array}{l}\text { once per } \\
\text { assessment }^{2}\end{array}$ & $\begin{array}{l}\text { once per } \\
\text { assessment }^{2}\end{array}$ & -- \\
\hline LAKES ................... & $\mathrm{P}$ or $\mathrm{D}$ & -- & -- & $\begin{array}{l}\text { once per assessment, } \\
\text { mid-summer }\end{array}$ & $\begin{array}{l}\text { semi-monthly, } \\
\text { March-October }\end{array}$ & $\begin{array}{l}\text { semi-monthly, } \\
\text { March-October }\end{array}$ \\
\hline
\end{tabular}

volunteer monitoring data, if that approach is used to increase sample sizes in some basins, could be less rigorous than the statewide assessment depending on the macroinvertebrate biomonitoring protocols followed by the volunteer monitors. Volunteer monitoring also would be very useful in bacteria sampling at probabilistic sampling sites, because the frequent sampling necessary for bacteria greatly adds to the resource requirements needed for the probabilistic monitoring program.
Sampling for field parameters also is proposed at probabilistic sites, for the aquatic life use and to provide general water-quality information. Field parameters also could provide some information to determine causes of impairment. For example, low dissolved oxygen could be identified as an impairment cause, although, as discussed previously, measurements made at the times of other sampling may not be ideal for identifying "worst case" conditions (which for dissolved oxygen would occur in pre-dawn hours). Other sampling to determine causes or sources 
is not proposed; macroinvertebrate community, as a response variable, will not determine causes or sources, although its ancillary information may be useful for this purpose. For example, the habitat analysis conducted as part of the macroinvertebrate biomonitoring could be used to identify sediment as an impairment cause. Information on causes and sources of impairment, however, is probably most useful when collected for specific reaches where remedial actions can be implemented, rather than at the large scale at which it would be provided by the probabilistic program. Sampling is not proposed to provide information to the assess all standards relevant to the aquatic life and recreational uses (table 2). Data also will not routinely be provided to determine use-support status for fish consumption. Fish consumption is assumed to be less relevant to the small streams sampled with probabilistic sites; third-order streams for which fish consumption is more relevant could be sampled in the deterministic part of the Tier I monitoring program. Some water-chemistry constituents that do not require specialized sampling techniques could be added for probabilistic sites. This would add relatively little to the costs of the monitoring program, because a large part of the cost of sample collection is for personnel making the site visit. Dissolved nutrients would be an example of constituents that could easily be added.

The resources required to implement the probabilistic sampling component of the Tier I monitoring program for streams will ultimately depend on the number of sampling sites selected. Based on previous estimates of time required for bacteria and macroinvertebrate sampling, a sampling program with 30 to 50 sites statewide would require about 171 to 285 personnel-days ( 0.8 to $1.3 \mathrm{FTE}$ ) for sample collection and processing. Additional time would be required for site selection, a pre-sampling survey of sites, and obtaining permissions from land owners for access and sampling, field work preparation, data management, and data analysis; the pre-sampling survey might require one to two months of time (A. Garceau, Indiana Department of Environmental Management, personal commun., 2000). Laboratory analyses are given in table 9. If status assessments were required for individual basins, these resource requirements would be multiplied by the number of basins (typically five) separately assessed.

\section{Deterministic Sampling Program}

Deterministic or targeted sampling is proposed for fourth-, fifth- (and larger), and some third-order streams in each basin. In the Neponset Basin, fourthand fifth-order streams are the middle and lower reaches of the mainstem Neponset and East Branch Neponset Rivers (fig. 6). Third-order streams are major tributaries to and the upper reaches of these rivers. In general for basins statewide, fourth-, fifth-, and the larger third-order streams would be defined as mainstem rivers in major basins, their major tributaries (streams draining the DEM-defined tributary watersheds), and other mid-sized streams in which DEP/DWM has a special interest. Deterministic sampling is proposed to meet DEP/DWM's need for information on water-quality conditions on specific reaches of these streams.

To design a deterministic sampling program for large streams, the length of stream represented by a single sampling point must be determined. It is not possible to do this in the absence of site-specific information on hydrologic conditions and the distribution of potential point and non-point contaminant sources near the sampling point. The length of stream represented by a sampling point, and the important features for determining those lengths, also may vary by sampling parameter. For example, a sampling site may be representative of a greater stream distance for a dissolved constituent such as nitrate than for a constituent that tends to be transported in association with particulates, such as phosphorus or metals, when low-velocity impounded reaches, where deposition may occur, are near the sampling site. Representative stream lengths for indicator bacteria are even more variable, because factors such as temperature, light, die-off, and biological interactions may also affect in-stream bacteria concentrations (Bowie and others, 1985). Thus general estimates of representative stream lengths for sampling sites made in advance of sampling are necessarily arbitrary assumptions, that often rely on "rules of thumb," such as 40 times the stream width.

For the purposes of this report, an arbitrary sampling density of about $5 \mathrm{mi}$ per sample is proposed for deterministic sampling of fourth-, fifth, and third-order streams for Tier I monitoring. This is consistent with USEPA's general recommendation that sampling sites should be considered to represent a maximum of 5 to $10 \mathrm{mi}$ for wadeable streams and $25 \mathrm{mi}$ for large streams (U.S. Environmental Protection Agency, 1997b). For 
Table 9. Resource requirements for a combined probabilistic-deterministic approach to Tier I monitoring in the Neponset Basin, Massachusetts

[Number of visits per location: One visit may include multiple sampling teams. Type of sampling: B, bacteria; C, chlorophyll-a; F, field parmeters; Ft, fish tissue; Mp, macrophytes; N, nutrients; Mv, macroinvertebrates; P, periphyton or phtyoplankton; Ss, suspended solids; Sx, sediment chemistry and toxicity; T, transparency; not all sample types are collected at each site visit. --, not applicable]

\begin{tabular}{|c|c|c|c|c|c|}
\hline \multirow[b]{2}{*}{ Water body } & \multirow[b]{2}{*}{$\begin{array}{c}\text { Monitoring } \\
\text { approach }\end{array}$} & \multicolumn{4}{|c|}{ Sample collection } \\
\hline & & $\begin{array}{l}\text { Number of } \\
\text { sampling } \\
\text { locations }\end{array}$ & $\begin{array}{l}\text { Number of } \\
\text { visits per } \\
\text { location }\end{array}$ & $\begin{array}{c}\text { Total } \\
\text { number } \\
\text { of visits }\end{array}$ & Type of sampling \\
\hline
\end{tabular}

STREAMS

\begin{tabular}{|c|c|c|c|c|c|}
\hline $\begin{array}{l}\text { First, second, and third } \\
\text { order }\end{array}$ & $\mathrm{P}$ & $30-50$ & 8 & $240-400$ & $\mathrm{~F}, \mathrm{~B}, \mathrm{Mv}$ \\
\hline Third order ......................... & $\mathrm{D}$ & \multirow{2}{*}{20} & \multirow{2}{*}{13} & \multirow{2}{*}{260} & $\mathrm{~F}, \mathrm{~B}, \mathrm{~N}, \mathrm{Ss}, \mathrm{Mv}, \mathrm{P}, \mathrm{Mp}, \mathrm{T}$ \\
\hline Fourth and fifth order........ & $\mathrm{D}$ & & & & $\mathrm{F}, \mathrm{B}, \mathrm{N}, \mathrm{Ss}, \mathrm{Mv}, \mathrm{P}, \mathrm{Sx}^{1}, \mathrm{Ft}, \mathrm{Mp}^{2}, \mathrm{~T}^{2}$ \\
\hline 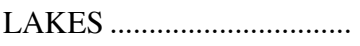 & $\mathrm{P}$ or $\mathrm{D}$ & 24 & 14 & 336 & $\mathrm{~F}, \mathrm{~N}, \mathrm{Mp}, \mathrm{T}, \mathrm{C}$ \\
\hline 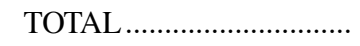 & & 74-94 & -- & $836-996$ & -- \\
\hline
\end{tabular}

\begin{tabular}{|c|c|c|c|c|c|c|c|c|}
\hline \multirow[b]{2}{*}{ Water body } & \multicolumn{7}{|c|}{ Laboratory analyses } & \multirow[b]{2}{*}{$\begin{array}{l}\text { Chloro- } \\
\text { phyll-a }\end{array}$} \\
\hline & Bacteria & Nutrients & $\begin{array}{l}\text { Suspended } \\
\text { solids }\end{array}$ & $\begin{array}{c}\text { Macro- } \\
\text { inverte- } \\
\text { brates }\end{array}$ & $\begin{array}{c}\text { Periphyton } \\
\text { or phtyo- } \\
\text { plankton }\end{array}$ & $\begin{array}{c}\text { Sediment } \\
\text { chemistry } \\
\text { and } \\
\text { toxicity }\end{array}$ & $\begin{array}{c}\text { Fish } \\
\text { issue }\end{array}$ & \\
\hline \multicolumn{9}{|l|}{ STREAMS } \\
\hline $\begin{array}{l}\text { First, second, and third } \\
\text { order }\end{array}$ & $240-400$ & -- & -- & $30-50$ & -- & -- & -- & -- \\
\hline Third order .......................... & \multirow{2}{*}{260} & \multirow{2}{*}{104} & \multirow{2}{*}{260} & \multirow{2}{*}{10} & \multirow{2}{*}{10} & -- & -- & -- \\
\hline Fourth and fifth order.... & & & & & & 10 & 10 & -- \\
\hline LAKES …........................... & -- & 24 & -- & -- & -- & -- & -- & 336 \\
\hline TOTAL …........................... & $500-660$ & 128 & 260 & $40-60$ & 10 & 10 & 10 & 336 \\
\hline
\end{tabular}

comparison, representative distances equal to 40 times stream widths are about $0.5 \mathrm{mi}$, with shorter distances for high-sloped streams and longer distances for lowsloped streams, based on width measurements for a limited number of major tributaries and smaller mainstem streams in Massachusetts (Parker and Gay, 1987; Parker and DeSimone, 1992). The arbitrary 5-mile sampling density differs from the systematic approach to defining stream reaches with uniform water quality, described previously for the exhaustive approach, in that its use incorporates no knowledge about how water-quality conditions in a stream are expected to vary. However, any deterministic (that is, non-probabilistic) approach to choosing sampling locations and relating point-sample information to stream lengths is subjective and requires assumptions about spatial vari- ability in water quality. Thus, a sampling density is proposed that is considered reasonable based on USEPA's recommendations, Massachusetts hydrography, and realistic resource limitations.

Choosing sampling sites at 5-mile intervals along fourth- and fifth-order streams in the Neponset Basin, which has $20 \mathrm{mi}$ of these streams, produces about four sites. It is proposed that the sampling sites be located near downstream ends of the stream reach being characterized. The rationale for this is that downstream locations have the potential for capturing the effects of point- and non-point contaminant sources and hydrologic conditions upstream of the sampling site, whereas sources and conditions downstream from a site cannot be represented by water-quality conditions at the site. 


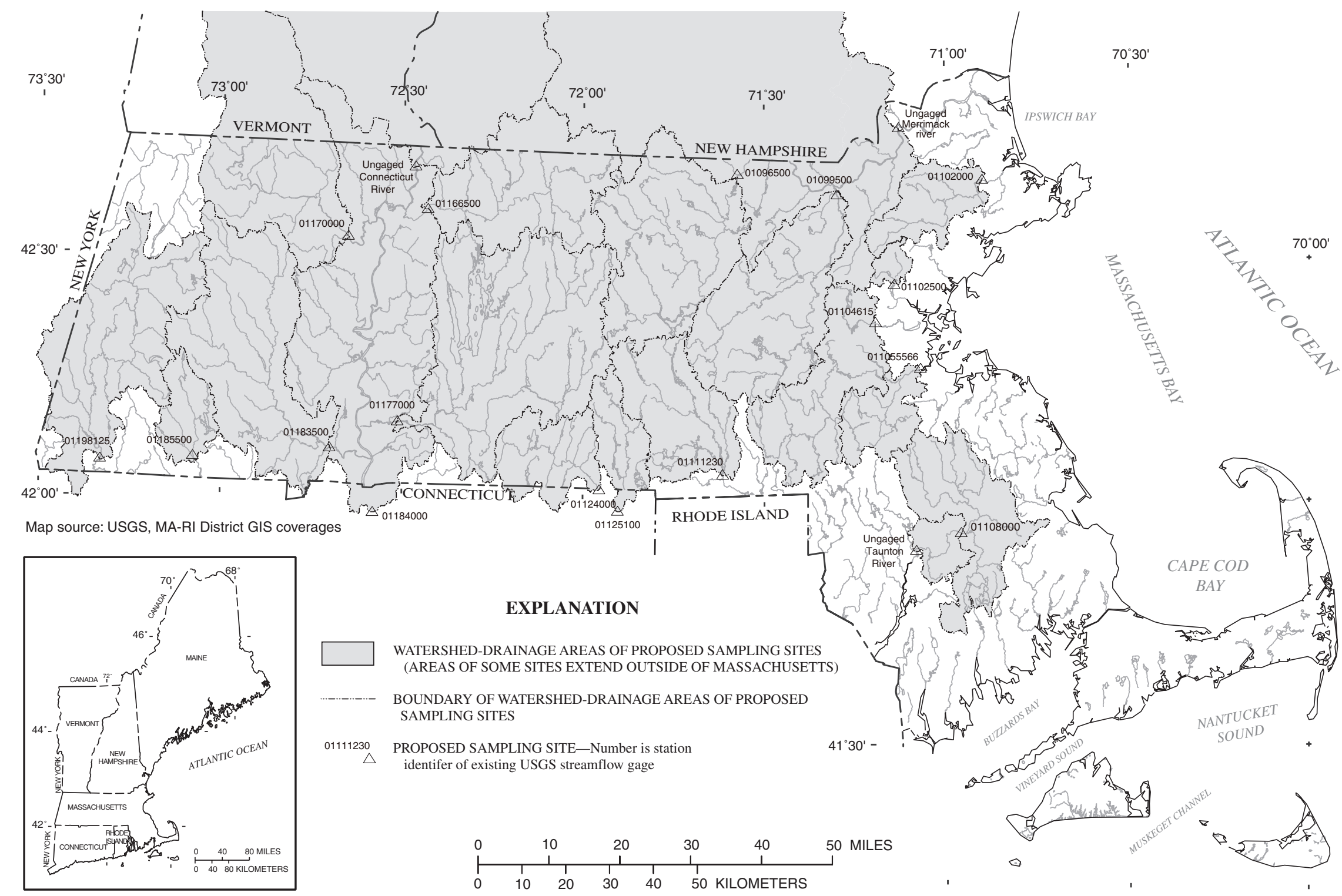

Figure 6. Locations and watershed-drainage areas of proposed sites for Tier II monitoring in Massachusetts. 
Thus, it may be more valid to extrapolate monitoring results upstream than downstream from a sampling site in many cases. Based on these criteria, deterministic sampling sites on in the Neponset Basin would include sites located (1) near the mouths of the mainstem Neponset and East Branch Rivers (two sites); (2) upstream of mainstem confluences, which in the Neponset Basin would be on the Neponset River upstream of the confluence with the East Branch (one site); (3) along the middle or upper reaches of the Neponset River, located to provide coverage at regular spatial intervals from other sites (one site); and (4) possibly other sites located upstream of major point sources and(or) urban areas (although it should be noted that targeting point sources or concentrated nonpoint-source areas with Tier I deterministic sites is likely to bias the overall assessment towards problem areas). The precise locations of the sites would be determined based on local conditions, such as wetlands, point sources, and so on.

In addition to sampling sites on the Neponset and East Branch Neponset Rivers, deterministic sampling sites are proposed for some fraction of their major tributaries, which are mostly third-order streams. Major tributaries could be defined by the DEM-delineated tributary basins, of which there are 14 in the Neponset Basin. Two of these are drained by fourth- or fifthorder mainstem segments, and some tributary watersheds have more than one large stream. Thus, 10 to 15 sampling sites might be adequate to characterize water-quality in major tributaries in the Neponset Basin. As with the mainstem sites, sampling sites would be proposed near the downstream ends of the tributaries, thereby integrating the effects of all sources in the watersheds. These sites could be used to characterize the entire length of the tributary or some portion that extends to its first- or second-order headwater segments.

Additional sites, for sampling by volunteers for some constituents, could be added to increase the number of tributary streams that are deterministically monitored or to increase the sampling density on mainstem reaches. As with macroinvertebrate sampling at probabilistic sites, careful planning, oversight, and quality control for volunteer efforts would be needed to ensure data quality and comparability. Care also would be needed when interpreting data that include these sites, so that the additional sites chosen based on local interest of volunteer monitors do not unduly bias the deterministic site selection scheme toward problem areas.

Sampling parameters proposed for deterministic sites include water chemistry, bacteria, fish community, fish tissue, and possibly sediment chemistry and toxicity, macroinvertebrates, and periphyton or phytoplankton (table 8). Water-chemistry and bacteria sampling is proposed for third-, fourth-, and fifth-order streams and would be used to assess contact recreation and aquatic life uses. Parameters include field parameters (temperature, specific conductance, $\mathrm{pH}$, dissolved oxygen, and turbidity), bacteria (fecal coliform and E. coli), nutrients, and suspended sediments. These parameters could be well suited to monitoring by volunteer groups, which commonly measured some or all of them for their own purposes (Dates and others, 2000), thereby increasing the number of stream miles deterministically assessed for contact recreation and aquatic life uses with water-chemistry. Sampling for periphyton or phytoplankton community and macroinvertebrates, response indicators for aquatic life use, also are proposed in large streams where appropriate. Sampling for metals is not routinely proposed for Tier I monitoring, as DEP/DWM has historically used toxicity testing and biomonitoring to determine whether adverse effects of metals have occurred (A.S. Johnson, Massachusetts Department of Environmental Protection, Division of Watershed Management, written commun., 2000). Metals sampling could be added, however, to address hot-spot, 303(d), or other site-specific information needs. Fish community measurements and fish tissue sampling for toxic contaminants are proposed on fourth- and fifth-order streams to address the aquatic life and fish consumption uses, respectively; fish sampling could be added for third-order streams as appropriate. Sampling for sediment chemistry and toxicity could be included at depositional areas near water-chemistry and fish sampling sites, as these parameters could be used to assess aquatic life use. Other sites, in large impounded areas of streams, also could be added, but may be more appropriate as part of a targeted monitoring program. It is not anticipated that volunteer monitors would have a large role in sampling for metals, fish community or tissue, or sediment, as these parameters require relatively sophisticated sampling techniques. Macroinvertebrate and periphyton sampling is proposed for wadeable sites included in this program, which are most likely to be the thirdorder stream sites. Techniques are available for 
macroinvertebrate sampling on nonwadeable streams (for example, Cuffney and others, 1993), but these are labor intensive and are not proposed for routine monitoring. Finally, macrophyte cover and transparency could be determined on large streams where appropriate, as described for the exhaustive approach.

Repeated sampling is needed to characterize many of the sampling parameters proposed for the deterministic sites because of their temporal variability. However, as with spatial sampling density, it is difficult if not impossible to make general determinations in advance of data collection of the sampling frequency needed to characterize individual water-quality parameters at unsampled sites. Generally, the number of samples needed to characterize a water-quality parameter increases with its variability. Methods are available to compute the number of samples needed to estimate the mean value of a water-quality parameter at a station at known precision and confidence level, if the statistical variance of the parameter at the station is known (Sanders and others, 1987); however, this information is not available at unsampled sites and can only be estimated at sampled sites with large sample numbers. Without previous knowledge of the temporal variability of water-quality characteristics at individual sites, many sampling programs of fixed stations use a uniform sampling frequency at all sites that is calendarbased but may include more frequent sampling in some months or hydrologic regimes. For example, the USGS National Water-Quality Assessment Program sampling protocols call for sampling of small and large basins in New England (drainage areas ranging from 23 to $10,000 \mathrm{mi}^{2}$ ) 18 times per year at most sites for field parameters, nutrients, major ions, and organic carbon (U.S. Geological Survey, 2000). These consist of monthly samples to capture seasonal variability and six additional samples targeted at high and low flows and storm runoff. Sampling for pesticides and VOCs, which are costly to analyze and potentially less variable, occurs once per assessment at some of these sites. More intensively monitored sites are sampled more frequently, for example weekly from April to August and monthly during the rest of the year (30 to 40 total samples) for all constituents, including pesticides and VOCs. These sampling frequencies are considered appropriate for objectives of determining nutrient loads to coastal waters and the effects of urban land use on stream-water quality (Lopes and Price, 1997; U.S. Geological Survey, 2000).
The number of samples considered adequate and their distribution in time also depends on the objectives of the monitoring program. For example, monitoring to calculate contaminant loads requires that the variability in concentration of the contaminant be well characterized over the range of flows in which the majority of its mass is transported. Monitoring to estimate annual average conditions at a site also requires that seasonal variation be well characterized. Monitoring for the status of waters with respect to water-quality standards, as in the Tier I monitoring described in this report, may be understood to call for monitoring during conditions when the standards are likely to be violated. Thus, sampling may not be needed year round for parameters for which impairment would be expected to only occur during summer months. Alternatively, sampling during the expected impaired period may be considered to bias the assessment towards "worse than average" conditions.

Finally, it is important to note that, for an assessment of existing conditions at the scale of the 305(b) assessment, it will not be possible to sample frequently enough to characterize individual water quality parameters with a level of confidence that might be considered statistically valid-sample sizes of 20 or 30 per site are not realistic for 305(b)-type monitoring. Rather, it is important to distribute the limited number of samples that are feasible over the range of conditions with which the parameters are expected to vary, where an understanding of those conditions exists. For example, many constituents, particularly those that are transported with sediment particles, vary with flow.

Sampling over the range of expected flow conditions at a site would be needed to characterize these parameters. Other parameters, such as indicator bacteria, are highly correlated with wet weather flows, so that sampling around storm events is needed. Guidance also is possible from water-quality standards that are written in terms of sample numbers. In most cases, however, resource limitations will ultimately determine the number of samples collected per site, because sampling frequency (along with site number) is a primary factor in the overall cost of a monitoring program (Sanders and others, 1987).

The sampling frequency proposed for the deterministic sites reflects both the need for repeated sampling for some parameters and a realistic expectation of available resources. In addition, it is assumed that sampling can be targeted to expected periods of impairment to meet the objectives of the assessment. 
Thus, for bacteria and suspended sediment, the proposed sampling frequency is monthly from March to mid-October (eight samples, wet or dry weather), with the collection of about five additional samples during this period targeted at rainfall-runoff events (wet weather). Field parameters also would be measured with these samples. As described for the exhaustive approach, criteria for defining wet- and dry-weather periods would be needed. This frequency is greater than the sampling frequency for dissolved oxygen and bacteria used in the 1994 Neponset assessment. Nutrients are proposed for sampling about monthly from March to October (eight samples), with some samples taken with the wet-weather bacteria samples as described for the exhaustive approach. The wetweather sampling for bacteria, suspended sediment and nutrients would be a good opportunity to incorporate volunteer monitoring, because it often is difficult and costly to deploy agency personnel for storm-event sampling. For sampling parameters other than water chemistry and bacteria, that is, fish community, fish tissue, sediment chemistry and toxicity, macroinvertebrates, and periphyton or phytoplankton, one sample per assessment is proposed. These characteristics integrate water-quality conditions over time and are much less temporally variable than water chemistry; composite samples or more than one sample per site could be considered for parameters, such as sediment chemistry, that are highly variable spatially. Volunteer monitoring would be less useful for these parameters, because specialized sampling techniques are required.

Resource requirements for the deterministic monitoring of streams were calculated using the time estimates previously described for the exhaustive monitoring approach. Estimates were made for the Neponset basin (table 9). For water-chemistry and bacteria sampling, 20 sites with 13 visits per site were assumed, requiring 200 to 264 personnel-days. The storm sampling included in these visits will need to include extra effort and non-standard working hours for agency personnel. Personnel estimates for waterchemistry sampling assume that the isokinetic depthand width-integrated methodology would not be used. For fish tissue and sediment chemistry and toxicity, 10 sites with 1 visit per site also would require 30 and 10 personnel-days, respectively. Six sites for fish community were assumed, for a total of 12 personnel-days (not shown in table 9). Finally, 10 macroinvertebrate and periphyton or phytoplankton sites would require 25 and 12 personnel-days, respectively, including sample processing. The total resource requirements for the deterministic monitoring are 193 personnel-days, or about 0.9 FTE; numbers of laboratory analyses are given in table 9. As with estimates for the exhaustive approach, most of these personnel-days would be needed during late spring, summer, and early fall. These estimates do not include time for site selection, obtaining permissions, field preparation, or data management and analysis.

\section{Sampling Sites, Parameters, Frequency, and Resource Requirements for Lakes}

The definition of sampling sites for lakes is less problematic than for streams, in that lakes are discrete water bodies. As with streams, it is proposed that lakes defined in the MassGIS 1:25,000 hydrography be used as the basis for selecting lakes for sampling. The previously described analysis of lakes in the Neponset basin identified those lakes larger than 5 acres for an exhaustive assessment of lake water-quality conditions. Forty-six lakes, represented 84 percent of total lake areas in the basin, met this criterion. This number of lakes may be too large to allow for a deterministic approach for the lakes assessment. A larger size criterion, 10 acres, would reduce the number of lakes included in the assessment for the Neponset basin by about half, to 24 lakes, but still assess 77 percent of the lake areas in basin. The larger size criterion is used for the present discussion.

A sample number of about 24 lakes per basin suggests that either deterministic (in this case, exhaustive) or probabilistic sampling may be possible for the lakes component of Tier I monitoring, within realistic resource requirements. A deterministic approach would provide some site-specific information on all lakes included in an assessment, such that impairments in any one of the lakes potentially could be identified and remedial actions could be initiated. A probabilistic approach would provide information on the overall status of all lakes as a group, in terms of the status with respect to the assessed uses, but would only provide site-specific information on a fraction of the lakes of interest in the sampled area. With the same amount of resources, however, the assessments could be more intensive, in terms of sampling parameters and frequency, with the probabilistic approach, because it would include fewer sampling sites. 
Whether a probabilistic or deterministic approach is used, sampling for field parameters, macrophytes, Secchi-disk transparency, nutrients, and chlorophyll-a is proposed for all lakes included in the assessment (table 9). Profiles of field parameters, for example at 2- to 3-foot intervals, are proposed for spring, mid- to late summer, and fall, from the deepest part of each lake. Available bathymetric maps, local knowledge, or best judgement would be used to select the sampling location. The profile measurements would indicate whether the lake becomes thermally stratified, and whether dissolved oxygen is depleted at depth; dissolved-oxygen depletion indicates lake productivity and the potential for mobilization of nutrients (phosphorus) or toxics (ammonia) from bottom sediments. These data would be used to assess aquatic life use. Macrophyte data would be used for aquatic life use along with primary and secondary (boating) recreation uses. Proposed measures are percent cover of floatingleaved, emergent, and submerged macrophytes and the presence or absence of non-native or nuisance plants, measured once in mid- to late summer. Percent cover could be estimated through visual inspection (floatingleaved and emergent) or several grab samples (submerged) for small lakes or through more quantitative mapping for large lakes.

Measurements of Secchi-disk depth and chlorophyll-a, which are important indicators of trophic status (Carlson, 1977; U.S. Environmental Protection Agency, 1998b), also are proposed at each lake. Although not linked to a specific designated use or State water-quality standard, the trophic state of the lakes provides valuable information for a status assessment, because most uses of lakes are adversely affected by increasing eutrophication. Secchi disk also could be used to assess primary contact recreation (swimming) use in terms of the State public-health standard for transparency. Secchi disk and chlorophyll-a are proposed for semi-monthly measurements from midMarch to mid-October, to capture the temporal variability resulting from phytoplankton population changes. The frequent measurements needed for Secchi disk and chlorophyll-a in lakes could benefit from the use of volunteers, as demonstrated by a recent USGS/DEP study (Waldron and others, 2001). Alternatively, less frequent measurements could be made, for example, in spring, midsummer, and fall only; with this schedule, Secchi-disk data would provide screening information only, to identify problem lakes. Volunteers also could be used to increase the number of lakes assessed in a probabilistic program, although local interest in lake quality may be tied to specific, rather than randomly selected, lakes. In addition to Secchi disk and chlorophyll-a, measurements of total phosphorus and nitrogen are proposed for lakes once per assessment, in spring. Nitrogen and phosphorus concentrations also are components of trophic indices for lakes (U.S. Environmental Protection Agency, 1998b). Although the temporal variability of these constituents would not be sampled, the nitrogen and phosphorus data would be useful to indicate potential problems in some lakes. Phytoplankon community analysis would integrate the effects of temporally variable nutrients concentrations and could be very useful for lakes assessments, but is not currently proposed.

This sampling program proposed for lakes, involving water chemistry, Secchi disk, chlorophyll-a, and macrophytes, is similar to USEPA's Tier 1 lake monitoring, which is considered appropriate for regional lake assessments (U.S. Environmental Protection Agency, 1998b). It provides data primarily for the aquatic life use, and, to a lesser extent, for contact recreation uses. Routine sampling for fish tissue, and fish community for the aquatic life and fish consumption uses are not proposed, because of expected resources limitations. Probabilistic monitoring of a randomly selected subset of all lakes in the five assessed basins per year for fish tissue could be used to provide an overall status estimate of the fish consumption use for 305(b) purposes. However, more useful information, in terms of public-health protection, might be obtained from a targeted sampling program for fish tissue that focuses on lakes identified by DEP/DWM and the MWI teams as high priority for the fish consumption use. Similarly, bacteria sampling for the swimming use is not proposed as a routine part of Tier I lakes monitoring. Bacteria sampling would require repeated site visits, some during wet weather, and probably multiple samples per lake. Moreover, many of the lakes identified for Tier I assessment may not be used for swimming. Thus, it is proposed that the swimming use be assessed on lakes with public swimming beaches only, and that local monitoring data be used for the assessment. It should be noted, however, that bacteria data are not likely to be available for all public beaches, so that an assessment based on local data only will be incomplete even for lakes with public swimming. A single "spot-check" sample could be collected on lakes used for swimming during the one-time visit for water chemistry and other parameters, but this 
would be of limited use given the inherent variability of bacteria concentrations. If information is required on bacteria concentrations for the swimming use in all lakes, a probabilistic approach would be proposed, as for the fish consumption use. Finally, the proposed sampling program for water chemistry, macrophytes, and other indicators for aquatic life use could be supplemented with more intensive assessments, with repeated sampling during the growing season and additional measurements, for specific lakes of interest in each basin for purposes other than the Tier I objectives. Volunteers from lake associations could be very useful in these more intensive assessments

Resource requirements for lakes monitoring can be estimated by assuming that each lake visit requires 0.5 days for 2 people for sample and field-data collection for most visits and 1 day for 2 people when nutrients, chlorophyll-a, and macrophyte sampling occurs. A boat is needed for the site visits, for water-chemistry profiles and sample collection from the middle of the lake and to facilitate macrophyte surveys. Thus, 408 personnel-days (about 1.9 FTE) would be needed for field work to assess lakes in the Neponset basin, if a deterministic approach is used. Most of this time would be concentrated in three field-work periods, in spring, summer, and fall. Additional time would be needed for field preparation, for data analysis and management, and possibly for a presampling survey for lake access.

Accurate bathymetry for all lakes would be useful for 305(b) assessment objectives as well as for objectives of TMDL development. Bathymetric information can be used to locate sampling site(s) on lakes for the 305(b) and other monitoring and to estimate flushing rates; flushing rates are important for evaluating lakes' susceptibility to nutrient loading effects and are needed for nutrient- or phosphorus-loading models such as used in TMDL development. Although not included in the scope of the current work, it is suggested that a program for measuring bathymetry of all lakes be considered. A recording fathometer coupled to a global positioning system would efficiently collect profile depth and position data at submeter accuracy for incorporation into a GIS coverage of lake bathymetry. The GIS could then be used to map the reservoir and compute morphometric features, including lake area, volume, maximum depth, mean depth, relative depth, and depth-area and depthvolume relations.

\section{Statewide Implementation of the Combined Probabilistic-Deterministic Approach for Tier I Basin-Based Monitoring}

Tier I monitoring programs would be implemented in conjunction with the 5-year, rotating-basin schedule of the MWI, as stated previously. The sampling program would be most effectively implemented in Years 2 (research) and 3 (assessment) of the cycle. Sampling plans developed for each basin by DEP/DWM for Tier I monitoring could be complemented with targeted monitoring plans, perhaps using a fixed number of sites per basin, developed by the MWI teams. Simultaneous implementation of the Tier I and targeted monitoring programs could enhance the efficiency and usefulness of both programs.

Special considerations may be needed when implementing the probabilistic monitoring program statewide. In particular, management-level decisions are needed, based on program and monitoring objectives as well as on resource limitations, about whether a sampling density should be used that will allow for assessment of the status of streams (a) within each individual basin (30 or more sites per basin, or 150 or more sites statewide) or (b) aggregated from all sampled basins across the state (30 or more sites statewide). With the latter approach, distribution of the probabilistic sites across the entire State, independent of the MWI cycle, might be a more effective design for the statewide estimate. Implementation of the probabilistic program over multiple 5-year cycles also requires consideration. In subsequent 5-year cycles, the same sites in each basin may be resampled, or new sites may be randomly selected. Sampling the same sites is likely to provide more information on water-quality trends over time. However, sites that are sampled in the first cycle and found to be impaired may have received remediation or other special treatment during the years between samplings, such that the sampling sites will no longer provide an unbiased estimate of ambient conditions in the second cycle (A. Olsen, U.S. Environmental Protection Agency, Corvallis, Oreg., oral commun., 2000).

The resources needed to implement the Tier I monitoring program across the State may be estimated from those determined for the Neponset basin. These resources were estimated, in terms of personnel-days needed for sample collection, from the number of sampling sites in the basin, the proposed number of visits per site, and assumptions about personnel time 
required to collect each sample type. Resource estimates for the Neponset Basin, however, cannot be simply multiplied by five to obtain resources needed to implement the program in five basins each year, because the Neponset Basin, at $117 \mathrm{mi}^{2}$, is considerably smaller than most major basins in the State. The 27 major basins average about $300 \mathrm{mi}^{2}$ in area, and the areas assessed by MWI basin teams average about $400 \mathrm{mi}^{2}$. The Neponset Basin itself is less than one-half of the area assessed by the Boston Harbor Watersheds team. Thus, many more sites would be needed in most basins than determined for the Neponset Basin for the two components of the program that vary with the number of water bodies being assessed, that is, the deterministic monitoring programs for large streams and lakes. The number of sampling sites for the probabilistic monitoring program for small streams is the same irrespective of the number of stream miles being assessed. The number of probabilistic sampling sites would substantially increase, however, if management decisions were made to assess use-support status of small streams individually for each basin included in the assessment, rather than to make a statewide assessment only - in the former case, resource requirements for the statewide estimate would be multiplied by the number of basins (typically five) assessed. With the statewide estimate only, about 30 FTEs for field sample collection and processing would be needed; this assumes that five basins, each requiring about twice the effort as the Neponset, are assessed per year. Laboratory analysis for the plan as described would require 2,840 to 3,000 analyses for bacteria (fecal coliform and E. coli), 1,280 analyses for nutrients (total nitrogen and total phosphorus or individual species), 2,600 analyses for suspended sediment, 130 to 150 macroinvertebrate, 100 analyses each for periphyton or phytoplankton, fish tissue, sediment chemistry, and sediment toxicity, and 3,660 chlorophyll-a analyses, for a total of 10,510 to 10,690 laboratory analyses. Personnel requirements for field aspects of the program would be needed primarily in late spring, summer, and early fall.

In addition to the personnel resources for field sample collection and processing, personnel time will be needed for pre-sampling site surveys, obtaining permissions, field preparation, data management, and other aspects of the program. It is difficult to estimate these personnel requirements. Time needed for program administration, data management, and similar activities is largely dependent on the specifics of the program's operation. For example, personnel time for data handling and management will vary depending on whether results are reported from analytical laboratories in digital or paper form, and on how much work is required to enter the results into the program's data storage system. Similarly, time for data reporting aspects of the monitoring program will vary greatly depending on the specific reporting venues. In the surface-water sampling component for a typical USGS NAWQA program, about 1.5 personnel-days are required for field preparation and data management for each personnel-day spent in the field collecting samples; additional personnel time is spent in this program for administration, planning, and reporting. For a USGS-based, statewide monitoring program in New Jersey, about 1.5 personnel-days are spent for field preparation, data management, and preparation of data for publication for each personnel-day in the field (Jacob Gibs, U.S. Geological Survey, oral commun., 2000). For a recent, less complex USGS sampling program for bacteria and nutrients in small streams, about 0.5 days were required for field preparation and data management for each field day. These rough estimates suggest that the FTE estimates made for field data collection components of the proposed monitoring program for Massachusetts could be about doubled, to about 60 FTEs, when time for field preparation and data management are included. The additional time for project administration, planning, site selection, and obtaining permissions could add several more FTEs. Again, however, it must be noted that these are only rough estimates and the actual personnel resources required by all aspects of the program may vary widely, depending on final makeup of the program. These substantial resource requirements could be reduced by eliminating or reducing assessment of some designated uses that require intensive sampling, such as the recreational use for small streams or frequent sampling of lakes for trophic status, or by using a probabilistic approach for lakes. Finally, in addition to personnel requirements, implementation of the proposed program would require resources for field supplies, transportation, laboratory analyses, and data storage.

Volunteer monitoring could be used in several ways to supplement agency resources to meet the fairly substantial personnel requirements of the proposed program for Tier I monitoring, or to enhance it. Volunteers could collect bacteria samples at probabilistic and deterministic sites, reducing the number of agency visits needed to these sites. Volunteers would be 
particularly helpful for wet-weather sampling, for which it can be difficult and costly to mobilize agency sampling teams. For lakes, volunteers could make some or all of the frequent Secchi-disk and chlorophyll-a measurements. Volunteer monitoring also could be used to provide more intensive assessments of some lakes, or to deterministically sample lakes of special interest if a probabilistic approach for lakes otherwise generally is taken. For streams, volunteer monitoring could enhance the proposed program through biomonitoring (macroinvertebrates) and bacteria sampling at additional sites on small streams, which otherwise are probabilistically sampled statewide, in basins where individual status estimates are desired. The status estimates using volunteer data could be less rigorous if less sophisticated biomonitoring protocols are followed by the volunteer groups than by agency personnel, but still could meet information needs for the basin. Finally, volunteer monitoring of additional sites on large streams could be used to increase the number of thirdorder streams that are deterministically monitored or to increase the sampling density on mainstem reaches, most likely for aquatic life (water-chemistry sampling) or recreational (bacteria sampling) uses.

Experience gained through implementation of the combined probabilistic-deterministic program for Tier I monitoring, as with all components of a proposed statewide network, would likely suggest ways in which the network design could be modified and improved. In fact, modifications and flexibility will likely be needed following initial implementation of the monitoring program. For example, sampling parameters could be added or dropped from the program, or sampling frequencies could be changed based on the analysis of the initially collected data. Careful consideration may be needed to ensure that short-term program modifications will not adversely affect the comparability of data collected during multi-year assessments. The statewide assessment of use-support status, which is a requirement of the CWA, will not be possible to obtain by aggregating individual basin-based assessments over 5 -year periods if the sampling program is altered too much from year to year or among basins.

\section{TIER II: FIXED-STATION MONITORING PROGRAM FOR CONTAMINANT LOADS IN MAJOR RIVERS}

The objective of Tier II of the statewide monitoring program is to determine loads of contaminants carried by major rivers in Massachusetts at strategic locations. This information is needed at the mouths of major rivers to quantify loads delivered to coastal waters, such as Boston Harbor, and major inland waterways, such as the Connecticut River. Information also is needed at State boundaries to permit the determination of contaminant loads entering and leaving Massachusetts. The sampling approach suited to the loads monitoring objective is fixed-station monitoring, where the same sites are sampled repeatedly over time and over a range of hydrologic conditions. Repeated sampling over time also generates data that may be suitable for determining trends in water-quality conditions and, over the longer term, for determining trends in contaminant loads.

\section{Sampling Sites, Parameters, and Frequency}

Candidate streams for Tier II monitoring include the mainstem rivers draining the State's 27 major basins. Nineteen sampling locations are proposed, generally on the largest rivers in Central, Western, and Eastern Massachusetts (table 10 and fig. 6). The proposed sampling sites are: near the mouths of the Merrimack, Aberjona, Charles, Ipswich, Neponset, and Taunton Rivers, which collectively drain to Boston Harbor, the Gulf of Maine, and Narrangansett Bay; at the mouths of the Millers, Deerfield, Chicopee, and Westfield Rivers, which discharge to the Connecticut River; at the mouths of the Concord and Nashua Rivers, which discharge to the Merrimack River, and at locations on the Quinebaug, French, Blackstone, West Branch Farmington, Housatonic, and Connecticut Rivers near where they enter and(or) leave the State. Because continuous streamflow records are needed for accurate loads calculations, most of the sites are proposed at or near existing gages. The need for streamflow data also limits potential sampling locations on rivers that drain to the coast to areas that are upstream of tidal influences and areas of sluggish 
Table 10. Sampling sites and drainage areas for Tier II monitoring to determine loads carried by major rivers in Massachusetts

[No., number; USGS, U.S. Geological Survey]

\begin{tabular}{|c|c|c|c|c|}
\hline \multirow{2}{*}{ River and sampling location } & \multirow{2}{*}{ Major basin } & \multirow{2}{*}{$\begin{array}{c}\text { USGS } \\
\text { station } \\
\text { No. }\end{array}$} & \multicolumn{2}{|c|}{ Drainage area, in square miles } \\
\hline & & & Massachusetts & Total \\
\hline Aberjona River at Winchester, Mass. ${ }^{1}$. & Boston Harbor / Mystic & 01102500 & 25 & 25 \\
\hline 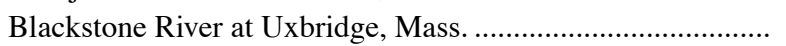 & Blackstone & not gaged & 244 & 244 \\
\hline Charles River at Watertown, Mass. ${ }^{1}$... & Charles & 01104615 & 271 & 271 \\
\hline 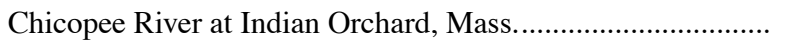 & Chicopee & 01177000 & 690 & 690 \\
\hline 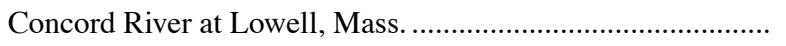 & SuAsCo & 01099500 & 399 & 399 \\
\hline Connecticut River at Thompsonville, Conn. ${ }^{2}$............................. & Connecticut & 01184000 & ${ }^{3} 2,526$ & ${ }^{3} 9,678$ \\
\hline 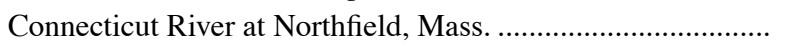 & Connecticut & not gaged & 26 & 6,745 \\
\hline 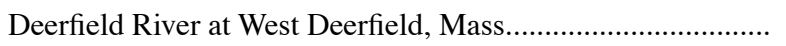 & Deerfield & 01170000 & 279 & 558 \\
\hline French River at N. Grosvenordale, Conn. ${ }^{2}$. & French & 01125100 & 95 & 102 \\
\hline Housatonic River at Ashley Falls, Mass. ${ }^{2}$.................... & Housatonic & 01198125 & 422 & 465 \\
\hline 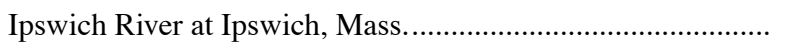 & Ipswich and Parker & 01102000 & 125 & 125 \\
\hline 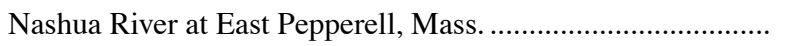 & Nashua & 01096500 & 418 & 435 \\
\hline 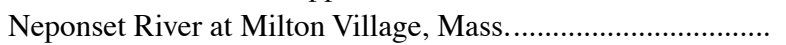 & Boston Harbor / Neponset & 011055566 & 108 & 108 \\
\hline Merrimack River near Haverhill/Methuen, Mass...................... & Merrimack & not gaged & ${ }^{4} 1,084$ & 44,746 \\
\hline 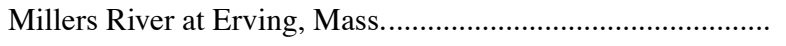 & Millers & 01166500 & 293 & 373 \\
\hline 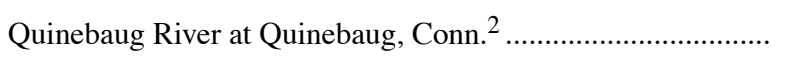 & Quinebaug & 01124000 & 135 & 151 \\
\hline 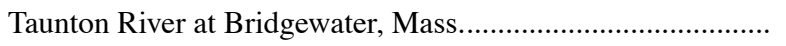 & Taunton & not gaged & 317 & 317 \\
\hline West Branch Farmington River near New Boston, Mass. ........ & Farmington & 01185500 & 92 & 92 \\
\hline 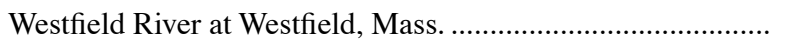 & Westfield & 01183500 & 496 & 498 \\
\hline
\end{tabular}

flow where streamflow cannot be gaged accurately. In most cases, such as on the Charles River and Aberjona Rivers, existing gages are already located as far downstream as possible for stream gaging. It may be possible to gage streamflow on the Taunton River further downstream than the existing gage; thus, an alternative is proposed that would be downstream of the Taunton urban area. Similarly, a new gage site is proposed on the Merrimack River, near the Haverhill/Methuen line, so that contaminant loads for the Merrimack River would include runoff from as many urban areas and major tributaries as possible. Two other sites are proposed for fixed-station monitoring that are currently are not gaged - the Connecticut River at Northfield, Mass., near the State boundary with Vermont and New Hampshire, and the Blackstone River at Uxbridge, Mass.
The exact location of each sampling site could be changed to accommodate specific water-quality information needs. For example, the proposed site on the Chicopee River at Indian Orchard, Mass., would exclude pollutant loads from urban runoff, combinedsewer overflows, and other sources associated with the City of Chicopee urban area, which is downstream of the proposed site. Similarly, loads to the Connecticut River from the Deerfield River, measured at the existing gage, would exclude the effects of sewagetreatment facilities discharging to the Green River, which joins the Deerfield River downstream of the gage. These site could be moved to capture the effects of the downstream contaminant sources. The site on the West Branch Farmington River, which is intended to represent loads from a relatively undeveloped watershed with no point sources, also could be moved farther downstream toward the Connecticut State border if desired. However, such water-quality information 
needs should be evaluated in the context of the resources required for establishing and maintaining a new streamflow gage to accommodate them, unless a nearby gage can be used to estimate streamflow at the sampling site.

Sampling at the proposed sites would provide information to determine contaminant loads from 67 percent of the total land area of Massachusetts (table 10). Unsampled areas in the proposed network design are primarily in Eastern Massachusetts. Many of the major basins in Eastern Massachusetts contain many, relatively small streams that discharge directly to the coast (fig. 7), and hydrology on Cape Cod and the Islands is dominated by ground-water flow. It would not be possible to conduct loads monitoring in these areas, given realistic resource limitations. One approach to characterizing contaminant loads from these areas would be to add a limited number of sites in small coastal watersheds that are considered representative of adjacent basins. These sites could be moved after sampling had been conducted for a sufficient time (several years) to adequately characterize contaminant loads on the sampled streams. For coastal streams of any size, alternatives to conventional stream gaging techniques would be needed to quantify loads from areas downstream from the furthest downstream gageable sites (fig. 7). Alternative approaches include methods for measuring flow through dams at river mouths or modeling and may require site-specific studies or monitoring programs. In some areas, such as near Boston, the downstream areas are heavily urbanized and contain significant sources of contaminants; thus, special studies may be desirable to characterize the water-quality conditions in these areas.

Sampling sites also could be added to the Tier II network to address information needs that are regional, rather than statewide, in scale. For example, a site in the upper Charles River Basin (near Medway) would be useful to track the trends in constituent concentrations due to the increased development in the upper portions of that basin. A similar argument could be made for the Assabet River (near Maynard), as this river basin is also affected by increased development along the Interstate 495 corridor. Other sites include the Weweantic and North Rivers, which are both coastal streams. The Weweantic River is influenced by cranberry cultivation within its basin, and the Weweantic and North Rivers both are affected by increased development.
Sampling parameters for Tier II monitoring are proposed to provide information on the waterquality issues of concern for each receiving waters or other monitoring location. Thus, loads of nutrients that stimulate eutrophication or other contaminants that impair the designated uses of receiving waters are of interest. Loads of nutrients and suspended sediments, which might be associated with organic contaminants such as PCBs, also are likely to be of interest across State boundaries. Sampling for field parameters (temperature, specific conductance, $\mathrm{pH}$, and dissolved oxygen), nutrients (nitrogen and phosphorus species), bacteria, and suspended sediment is proposed for all Tier II sites. Sampling for bacteria (fecal coliform and E. coli; Enterococcus, an indicator for salt water, could be included for coastal sites) also is proposed, to provide additional, general information on the status of waters for the contact recreation uses. Sampling for other parameters, such as selected metals or organic compounds, could be added based on specific information needs at some sites or previous knowledge of impairments, for example, at sites near the Massachusetts-Connecticut boundary.

Sampling frequency for Tier II monitoring is determined by the need to adequately characterize the range of hydrologic and seasonal conditions for loads calculations. Thus, about monthly sampling frequency is needed, but samples need not be at strictly regular intervals. Additional samples will likely be needed during high- and low-flow periods to fully cover the range of hydrologic conditions and characterize wet-weather conditions. This is particularly important for suspended sediment and sediment-associated contaminants such as phosphorus and metals, because sediment concentrations are variable and depend on changing flow conditions. Fifteen, isokinetic depth- and width-integrated samples per year at each site are initially proposed; this sampling frequency is consistent with the recently redesigned USGS NASQAN sampling program for contaminant loads on freely flowing large rivers (Hooper and others, 1997). The sampling frequency could be revised after several years of data collection and analysis, if it were determined that less frequent sampling were adequate. The sampling frequency also could be enhanced by the use of volunteers or paid local observers. Volunteer monitors would be particularly useful for sediment and sediment-borne contaminants, because daily or more frequent (during high flows) sampling could be needed to adequately quantify sediment loads (Edwards and Glysson, 1999). 


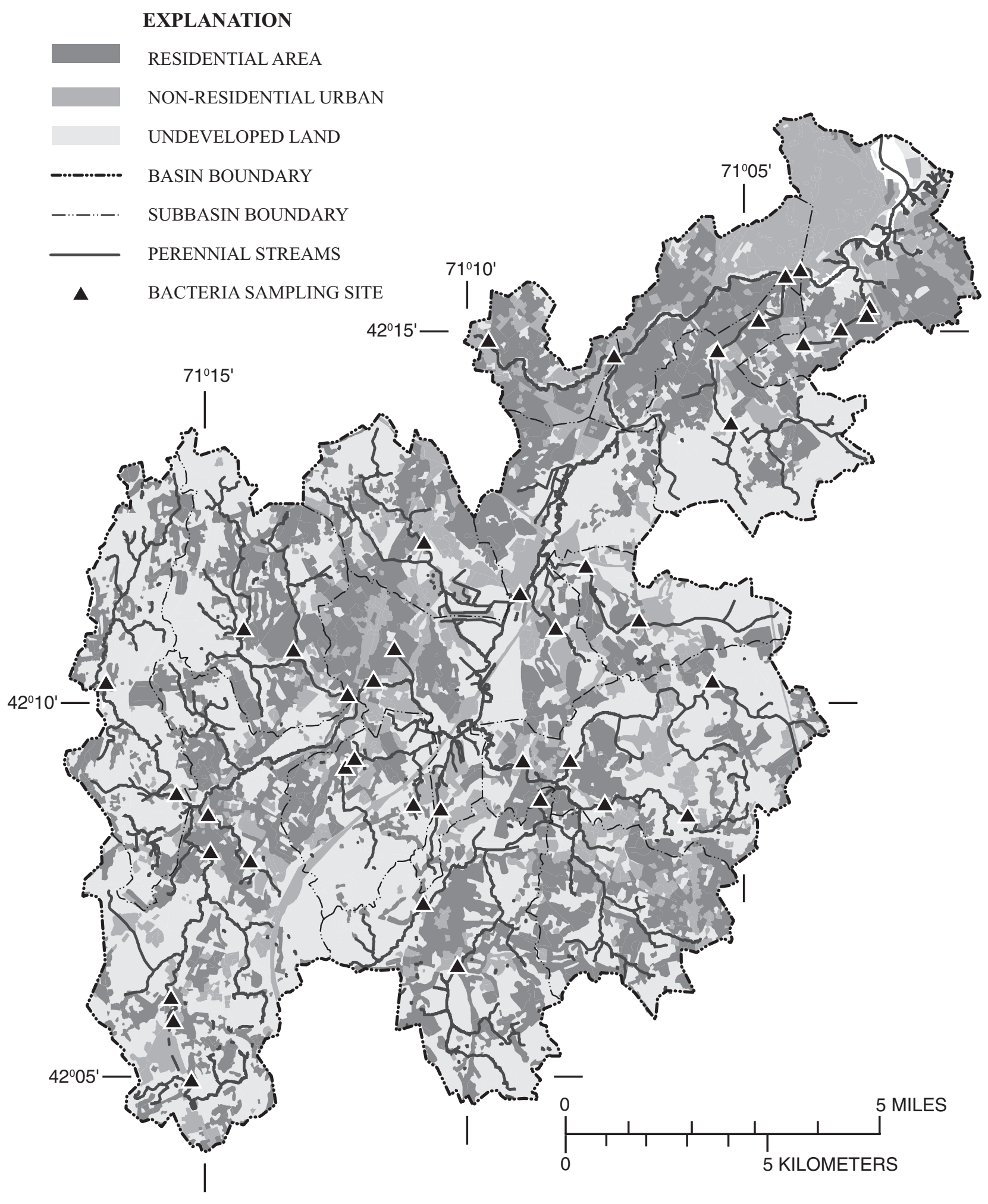

Figure 7. Sites sampled for bacteria for hot-spot monitoring in the 1994 Neponset water-resource assessment and generalized land use in the basin. Land-use data from MassGIS; undeveloped land use as shown includes a small amount of agricultural land use. 
A recommended approach is that volunteers collect point or single-profile, depth-integrated samples, and statistical relations are used to relate these samples to the depth- and width-integrated samples collected by agency personnel for use in loads calculations (Edwards and Glysson, 1999). Continuous measurement of field turbidity, in conjunction with frequent samples collected by agency personnel or volunteers, could be used to develop relations between turbidity and sediment concentration that would allow for more accurate calculation of sediment loads (Christensen and others, 2000).

\section{Resource Requirements}

Resource requirements for Tier II monitoring were defined in terms of the personnel requirements for sampling collection, the laboratory analyses needed, and the costs for stream gaging at currently ungaged sites. Sampling the 19 proposed stations 15 times per year requires 270 site visits and samples for analysis annually. It is expected that 0.5 to 1 day would be required for each visit for one to two people, depending on travel distances, the proximity of sites, and the sampling parameters at each site. Site visits in which metals samples were collected would always require two people, to implement the low-level sampling protocols; metals sampling also would require extra fieldwork preparation time to pre-clean sampling equipment. Sampling of two or even three sites per day may be possible when two-person crews are used, and samples are taken at existing stream gages (such that streamflow need not be measured at the time of sampling). One-person crews may be appropriate for some sites with one visit per day. However, sampling large rivers typically is conducted with two-person crews, because it entails the use of specialized equipment that is deployed off bridges or boats and because of safety concerns, especially under high-flow conditions. Assuming that one-half of the stations require 0.5 days per visit and half require 1 day for two people, 500 personnel-days (about 2 FTEs) would be required for sample collection for Tier II monitoring, with some additional time needed for field-work preparation. The laboratory analyses needed for these samples would include 285 analyses for nutrients (total nitrogen and phosphorus, or separate analyses of nitrogen and phosphorus species) and bacteria, at least that many analyses for suspended sediment (probably many more), and a lesser number of analyses metals.

The resources required for sampling the Tier II sites could be reduced through cooperative agreements among States. Specifically, sampling at the Quinebaug, French, and Connecticut Rivers (Thompsonville, Conn.) currently is being conducted by the USGS, Connecticut District, in cooperation with the Connecticut Department of Environmental Protection. Alternative sites on these streams in Massachusetts could be chosen for inclusion in the Massachusetts monitoring program, but a more efficient use of resources would be to share sampling costs at sites near the Connecticut and Massachusetts boundary between the two States. Similarly, water-quality samples are currently being collected at a site on the Blackstone River in Millville, Mass., about 3 mi downstream from the proposed Blackstone site, by the USGS in cooperation with the Rhode Island Department of Environmental Management. Because the Millville site is not suitable for flow measurement, the alternative site in Uxbridge, Mass., was proposed. Cost-sharing between Massachusetts and Rhode Island could be considered for the Blackstone River sampling to maximize the use of monitoring resources and avoid redundancy in data collection. Resources also would be required for establishing and maintaining new streamflow gages at currently ungaged sites.

\section{TIER III:TARGETED MONITORING PROGRAMS}

Monitoring that targets particular locations, areas, or issues is categorized in the statewide network design as Tier III monitoring. It includes data collection for 303(d) listing of impaired water bodies as required by the CWA, hot-spot monitoring, and other site-specific investigations. Because these programs are focused on specific issues or areas rather than providing more general information on the status of waters over a wide area, their monitoring designs will vary significantly based on site characteristics and monitoring objectives.

Monitoring for 303(d) listing is conducted on specific reaches of identified water bodies. Such monitoring could verify an impairment indicated by reconnaissance-level sampling, in order to place the water body on the State's 303(d) list, or confirm the 
impairment of an already listed water body. An example of this type of monitoring is wet- and dry-weather sampling by the USGS and DEP/DWM for selected metals at a site on the Mystic River in Medford, between Lower Mystic Lake and the Amelia Earhardt Dam, a reach that is currently listed as impaired by toxics (Commonwealth of Massachusetts, 1999). Data collected for these purposes is defined by the water-quality problem of interest and must be of high quality. High-quality, well-documented data are needed because the monitoring results may affect the development of TMDLs for the sampled water bodies and may need to be legally defensible. For these reasons, professional water-quality sampling may be required for this type of Tier III monitoring. The highest level of quality control and documentation would be needed for volunteer monitoring data to be used.

Monitoring of known or suspected impaired waters or monitoring to identify impairment sources is hot-spot monitoring. Hot-spot monitoring is an important objective of the MWI teams (A.S. Johnson and W.R. Dunn, Massachusetts Department of Environmental Protection, written and oral commun., 1999). It differs from monitoring for the statewide 305(b) assessment, which also yields information on impaired water bodies over a wide area, in that its focus is on impairments in specific streams and reaches so that remedial actions can be taken rather than to provide information on the overall status of all streams in the area. Hot-spot monitoring, as discussed in this report, also differs from the kind of systematic sampling program that would be required to locate impaired waters in a basin without any prior knowledge of their likely distribution. Hot spots are defined here as sources of impairments, rather than the resulting impaired or con taminated stream reaches, and monitoring approaches for locating such sources are discussed in this section. The discussion focuses on streams; approaches for lakes or other water bodies would differ based on their specific hydrologic regimes. As with Tier I monitoring, a review of the 1994 MWI pilot assessment of the Neponset Basin is used to provide context for the discussion of hot-spot monitoring strategies.

In the 1994 Neponset assessment, contamination of surface waters by fecal bacteria was a known major problem throughout the basin (Kennedy and others, 1995). This knowledge was used to design a sampling program to identify sources of bacterial contamination in the basin. Other objectives of the sampling program included a basin-wide assessment of existing conditions for compliance with State waterquality standards, information on occurrences of toxic contaminants in water, sediment, and biota, and a biological integrity assessment of the Neponset River and some of its major tributaries (Kennedy and others, 1995, p. 1-2). It is important to consider these other objectives because the same sampling sites were used for these purposes as well as for the hot-spot monitoring.

The monitoring program for bacterial contamination in the 1994 Neponset study used 41 sampling sites. No information is provided on the approach or criteria used for site selection (Kennedy and others, 1995). The sites are located along the mainstems of the Neponset ( 8 sites, primarily in the upper segment) and East Branch Neponset Rivers (1 site) and along nearly all of their major tributaries (32 sites, along 16 of 18 tributary streams; Halliwell and others, 1982; fig. 7). One to four sites are located along each mainstem segment or tributary, distributed at varying points from headwaters to mouths. Thus, the monitoring program appears to have used, at least in part, a geographically based, targeted approach to distribute sites among streams in the basin. Other criteria, such as local knowledge of problem areas, also may have been used to select streams for sampling or to locate sites along streams, but it is not possible to infer these procedures from the information provided in the report. Most (31) sites were sampled 3 times, on July 19, August 16, and October 18, 1994. Several sites also were sampled on December 12, 1994 (4 times total), or were sampled on only one or two of the sampling dates. The July and October sampling dates represented dry-weather conditions, whereas the August sampling date was marginally wet weather in that it occurred 2 days after a substantial storm.

In general, the bacteria data collected in the 1994 study were primarily used to identify and prioritize impaired reaches rather than to locate specific sources of impairment. The prevalence of fecal coliform concentrations exceeding state standards (standards exceeded at 30 of 41 sites) also was used to confirm the finding that bacterial contamination was a major waterquality problem in the basin (Kennedy and others, 1995 , p. 2-15). Sites were prioritized based on relative concentrations on a basin map. In terms of source identification, the elevated fecal coliform concentrations in dry- as well as wet-weather samples were used to conclude that sources in the basin were likely to be leaking sewer lines and failed septic systems, as well as 
stormwater runoff. A specific source was identified in only one instance. Exceptionally high fecal coliform concentrations (32,000 to 224,000 colonies per 100 milliliters) were measured in Meadow Brook (fig. 2), a channelized tributary to the Neponset River that drains the urban center of Norwood. These results led to infrastructure investigations by the Town of Norwood in the Meadow Brook drainage area, through which leaking sewer lines were identified and remedied. Specific sources for which remedial actions could be initiated were not identified for the other 29 impaired sites. The authors of the report recognize that additional sampling was needed for source identification and for monitoring the effectiveness of ongoing management actions (Kennedy and others, 1995).

The 1994 Neponset study illustrates the framework for an effective approach for hot-spot monitoring, but also demonstrates the potential difficulties of using a single monitoring design for multiple, and to some extent conflicting, objectives. The bacteria sampling sites were intended to identify reaches that were contaminated by bacteria as well as the sources of the contamination; a third objective was to provide information on the status of waters in the basin with respect to water-quality standards for bacteria for contact recreational uses [the 305(b) assessment]. The most effective approach to locate specific impaired reaches is a systematic, geographically distributed sampling program; such approaches have been developed for locating highly contaminated areas at hazardous-waste sites using sampling grids (Gilbert, 1987). Knowledge of the expected locations of the impairments allows for more efficient sampling, in that expected contaminated areas can be sampled more densely. However, for an assessment of existing conditions throughout a basin, this kind of targeted sampling is likely to lead to biased results, because contaminated areas are preferentially sampled. For the identification of impairment sources, a multi-purpose sampling program also may not be adequate because source identification usually requires follow-up water-quality sampling or other types of investigation, as with the Meadow Brook example in the Neponset Basin. Resources may not be allocated or remaining for these investigations once the overall sampling program is completed.

Effective programs for hot-spot monitoring are based on substantial knowledge of identified or suspected problem areas and on site and contaminant characteristics. Sources of knowledge about problem areas are historical water-quality data, land-use data, and local observations or anecdotal reports of impairments. This information can be gathered by the MWI teams and used for site selection. Monitoring data at all quality levels and the local knowledge of volunteer groups also could be very effective, for site selection or source identification. In the tiered network design described in this report, the probabilisticdeterministic sampling program for basin-based 305(b) monitoring is another source of knowledge about problem areas. Types or causes of impairments prevalent in a basin and specific impaired reaches could be identified through the relatively extensive water-quality sampling proposed for larger streams. For smaller streams, in which macroinvertebrate sampling (a response variable) and bacteria sampling only are proposed, less information would be provided on chemical or physical causes and geographic distribution of impairments; however, Tier I sampling in individual basins could be augmented with additional water-quality parameters on these streams for reconnaissance-level identification of impairment causes.

Once known or suspected hot spots are identified, specific sampling programs could be designed based on the sites and contaminants of concern. Goals of the program would be to confirm existence of the problem, document its persistence and variability, or determine whether inferences as to its source can be made from sampling results. The sampling parameters and temporal and spatial scales for sampling depend on site conditions and cannot be specified in advance. Sites downstream of a known hot spot, such as a ground-water plume discharging to a stream or a combined-sewer overflow, may be sampled repeatedly over time to characterize its effect on stream quality under varying hydrologic conditions or to document improvements from remedial actions. Sites at suspected hot spots would be similarly sampled, except that less information would be available to guide the sampling program. When a suspected problem area is confirmed, a second phase of sampling may be needed, in which sampling sites are chosen upstream to locate the area of maximum contamination. Existing knowledge of land uses and potential non-point and point sources along the sampled reach and its tributaries could be used to guide the second phase of sampling. The Meadow Brook site in the Neponset Basin is an example where infrastructure investigation without any additional water-quality sampling was sufficient to identify a source to the extent that remediation could be achieved. Another example, where more additional work is needed for source identification, is an ongoing 
investigation in the Millers River by the USGS, DEP, and MWI basin team, where a several-year study with repeated sampling along 44 stream miles is being conducted to locate the source of PCB contamination in fish and sediments in the river.

Because knowledge of impaired areas is an important basis for hot-spot monitoring, the 1994 Neponset bacteria results also were used to investigate whether GIS procedures could be developed that would substantially aid site selection for identifying impaired reaches. Land-use data from MassGIS (1995 data at 1:25,000-scale; MassGIS, 1997) were aggregated into generalized categories of residential, non-residential urban, and undeveloped uses, reflecting their expected contribution of bacteria to surface waters (fig. 7: the undeveloped land-use category, shown with agricultural land use in figure 7, did not include agricultural land use in the statistical analyses). Mean and median fecal coliform concentrations at the 41 sampling sites were compared with percentages of these three generalized land uses in (a) the entire watersheds of the sampling sites (mean and standard deviation of watershed areas equal to $9.2 \pm 21 \mathrm{mi}^{2}$ ), (b) watershed areas extending upstream to the watershed of the next tributary confluence or significant lake ("incremental watershed area", mean and standard deviation equal to 0.64 $\pm 0.65 \mathrm{mi}^{2}$ ), and (c) 200-foot riverfront buffer areas along the streams, extending from the sampling site upstream to the next tributary confluence or significant lake (mean and standard deviation of lengths equal to $0.58 \pm 0.56 \mathrm{mi}$ ). Tributary confluences and significant lakes were chosen as the upstream boundaries to landuse areas used in the comparison, rather than using a uniform distance upstream from the sampling site, to minimize the effects of dilution from tributary inflows, variable streamflow velocities (Parker and DeSimone, 1992), and variable attenuation from die-off, sedimentation, or other factors during transport through lakes (Bowie and others, 1985). Concentrations and land-use percentages were compared directly using the nonparametric Spearman Rank correlation test and by comparing land-use percentages between groups of sites where State bacteria standards for primary contact recreation were exceeded and not exceeded using the Mann Whitney test.

If land use were found to be an indicator of fecal coliform contamination, the watersheds and stream reaches throughout the basin could have been analyzed in terms of land use to determine how well the siteselection scheme of the 1994 assessment sampled all the watersheds or stream reaches in the basin that were likely to be impaired. However, no statistically significant (alpha equal to 0.10) relations were found, except for a weak correlation between median fecal coliform concentrations and residential land use in incremental watershed areas of the sampling sites. The importance of residential land use as a source of bacteria to streams is consistent with literature reports (for example, Bladys and others, 1998; James and others, 1998, and references therein); however, these results did not support additional quantitative review of the 1994 sampling results.

The general lack of statistically significant relations among land use and bacterial concentrations found here likely results at least in part from the limited scope and available data for the analysis. However, it also illustrates the difficulties in using land-use data in the absence of any other, local knowledge to identify specific impaired reaches for contaminants like bacteria. Sources of bacteria, which include stormwater runoff, leaking sanitary sewers, illicit connections to storm sewers, combined-sewer overflows, and waterfowl (Weiskel and others, 1996), are in general associated with specific land uses but also are highly variable within mapped land-use categories, and in-stream processes affecting bacteria are complex. Thus, results of investigating the 1994 sampling program confirm the central role of site-specific knowledge in the design of hot-spot monitoring programs.

Because hot-spot monitoring programs are issue-, site-, and basin-specific, the resources required for an effective program for this component of Tier III of the statewide network cannot be defined in advance. As with other components of a statewide network, the scope of hot-spot monitoring programs in basins must be defined at least in part by the resources available for the effort. One approach would be for a regulatory agency, such as DEP/DWM, to work with groups well situated to collect local and historical knowledge, such as the MWI teams, to identify and prioritize problem contaminants and problem areas in a basin for each assessment cycle. This process could be informed by reconnaissance-level sampling by volunteer groups and(or) by Tier I monitoring results. Resources then could be allocated, based on the total amount of resources available for this component of a statewide network and the relative severity of the identified problems among and within basins. Detailed hot-spot monitoring programs then could be designed that would effectively address the specific problem areas and issues. 
TIER V: STRATEGIES FOR COMPLIANCE-BASED AMBIENT MONITORING

Thousands of water-quality samples are collected annually in Massachusetts to document or determine compliance with regulations governing water quality of wastewater discharges, water supplies, and other municipal and private entities. Data collected for compliance-monitoring programs may be difficult to interpret in terms of ambient conditions, however, because analyses are performed on treated water or wastewater or on natural waters that are directly affected by pollutant sources. One alternative for enhancing the efficient use of limited monitoring resources is to modify compliance-monitoring programs to provide ambient data that supports the multiple water-quality information needs of Massachusetts.

The National Pollutant Discharge Elimination System (NPDES), a permit program under the regulatory authority of the Federal CWA, is administered by USEPA and the States. In accordance with the CWA, all point-source discharges of pollutants to U.S. surface waters must be permitted under the NPDES program (U.S. Environmental Protection Agency, 1997c). A NPDES permit specifies the quantity and quality of waste or effluent that may be discharged by a permittee or facility to a specific water body (or "receiving water"). The permit generally also specifies a monitoring program that must be conducted by the permittee to determine that permit standards are being met. Typical NPDES permittees include municipal sewagetreatment facilities, which discharge treated effluent, and industrial facilities, which may discharge treated wastewater, cooling water, or stormwater; receiving waters may be streams or coastal waters. Permitted NPDES discharges also include municipal storm sewer systems serving populations of 100,000 or greater and some large construction projects (U.S. Environmental Protection Agency, 2000). Monitoring programs in NPDES permits commonly include periodic (daily, weekly, or monthly, for example) sampling of effluent at discharge locations for temperature, suspended solids, fecal bacteria, oil and grease, specific toxic pollutants (for example, metals or solvents), or nutrients; monitoring programs are tailored to specific facility operations and discharge types. Permitted NPDES dischargers are classified as "major" or "minor" based on the volume of effluent or other water discharged.
Compliance monitoring for the NPDES program in Massachusetts was evaluated as a potential source of ambient water-quality data by analyzing the locations of permitted major NPDES discharges as potential stream-quality sampling sites. Sites were analyzed in terms of geographic distribution among major basins in the State, stream order of the receiving water, and upstream watershed areas of sites. Stream order of the receiving water is a measure of the distribution of sites among streams of varying sizes and is used to evaluate how well the major NPDES discharge locations would serve for a statewide assessment of existing conditions in streams, as outlined in Tier I of the monitoring design described in this report. Information on upstream watershed areas of sites is useful for evaluating how well the major NPDES discharge location would serve as a network of sites for determination of contaminant loads, as outlined in Tier II of the monitoring design. It should be noted that the use of compliance-monitoring sites for the collection of ambient water-quality data for these purposes requires special considerations, which also are discussed in this section.

A preliminary data layer of permitted major NPDES discharges in Massachusetts was obtained from DEP for this analysis (Brian Brodeur, Massachusetts Department of Environmental Protection, written commun., 1999). This data layer, currently undergoing field checking and revision, was the best available representation of NPDES discharge locations at a statewide scale. Some NPDES permittees were represented by multiple point locations in the data layer, which may have corresponded to facility buildings, pipe outlets, or discharge lagoons. Discharges were identified by the NPDES permit number, facility name, facility type (for example, municipal or industrial), and receiving water of the discharge. The data layer contained 205 discharge locations, which were associated with 155 permitted discharges to surface waters across the Commonwealth.

The preliminary NPDES data layer was modified by replacing multiple discharge locations with a single point feature for each discharge permit that was located on the receiving-water stream as represented by the MassGIS digital hydrography (1:25,000-scale centerline data) For discharge permits represented by a single point in the preliminary data layer, this point feature also was moved to the receiving stream where necessary. These modifications were not made, however, for discharge locations in brackish water, estuaries, or coastal waters, where centerline locations could not be 
determined, or for discharge locations in basins for which centerline data layers were not currently available. Centerline data layers were not available for the North Coastal and Buzzards Bay basins; a preliminary version of the centerline data layer for the Taunton basin was obtained from MassGIS and was used in this and other NPDES-related analyses. The modified NPDES data layer is shown in figure 8.

Strahler stream order of discharge-location sites was determined in ARC/INFO on a basin-by-basin basis, for all basins except the North Coastal and Buzzards Bay basins. Stream-order definitions in this analysis were based on both perennial and intermittent streams, because elimination of intermittent streams from each basin's centerline data layer would have required detailed GIS editing that was beyond the scope of this analysis. In addition, watershed areas of sites were delineated in ARC/VIEW using the MassGIS Data Viewer's Watershed Analyst (MassGIS, 2000a, 2000b) for all sites except those located in the North Coastal, Buzzards Bay, and Taunton basins, where the Watershed Analyst was not available at the time of the analysis.

Major NPDES discharge locations are distributed throughout the State, although the density of sites generally is greater in eastern basins than in western basins (table 11 and fig. 8). Several basins, including the Cape Cod and Islands, Farmington, Shawsheen, and Westfield basins, have few or no discharge locations to streams. As might be expected, the discharge locations are disproportionately located on large streams. Sixty-two percent of all locations (79 percent of sites for which stream order was determined) are on fourth-order or larger streams; these streams are likely to account for only about 20 percent of the total perennial stream miles in the state, based on analysis of the Neponset Basin (table 4). Only 7 percent of discharge sites ( 9 percent of sites for which stream order was determined) are located on first-order streams, which accounted for nearly half of the perennial streams in the Neponset Basin.

A sampling network that used major NPDES discharge sites for a statewide assessment of existing conditions in streams for 305(b) and similar purposes would be based on a targeted or deterministic monitoring approach. Because site selection is deterministic rather than probabilistic, conditions in the sampled streams could not be readily extrapolated to unsampled streams with an NPDES-based network. Thus, 100 percent coverage of stream miles in the state would not be possible. An estimate of the coverage potentially provided by sampling at major NPDES sites can be made by making assumptions about the lengths of streams represented by samples at the discharge sites, that is, about stream reaches adjacent to the sites that would be expected to have relatively homogeneous water quality and biological integrity. Assuming lengths of 3 stream miles per site for first- through third-order streams and 5 mi per site for fourth-order and larger streams, a total of 553 stream miles, or less than 10 percent of the total perennial stream miles in the state, could be assessed. The majority ( 86 percent) of these stream miles would be fourth-order and larger streams, such that a statewide assessment based on NPDES sites alone would be biased towards larger streams. Sampling at NPDES sites could be combined with other parts of a Tier I monitoring design to increase the overall coverage provided by the deterministic components of a Tier I design. However, sites provided by the NPDES network may not be optimum for several reasons, discussed further below.

The distribution of major NPDES discharge sites might be more appropriate for a network with objectives of determining contaminant loads (Tier II objectives), rather than for a statewide status assessment. The total watershed areas of NPDES sites in basins where watersheds could be delineated (123 sites, excluding sites in the Buzzards Bay, North Coastal, and Taunton basins) is $5,062 \mathrm{mi}^{2}$, which is a large fraction (72 percent, excluding areas of the three basins listed above) of the total land area of Massachusetts. Many of the NPDES sites are located on the mainstem rivers that would be of interest for contaminant loads, although the sites are unlikely to be at the specific locations (river mouths or State boundaries) of interest in most cases. Where discharge sites were well located, sampling could occur upstream of the discharge location(s) for ambient loads or water-quality, or upand downstream if data also were needed to characterize the discharge's effect on stream quality, for example, as part of a TMDL program. Samples at downstream locations also could be used to identify the need for increased treatment or upgrades at the discharging facility (D.R. Dunn, Massachusetts Department of Environmental Protection, written commun., 2000). Potential sites for each facility would need to be evaluated by an experienced water-quality professional to identify locations suitable for sampling and flow measurement with respect to streamflow, the point source(s), in-stream mixing, and other factors; 


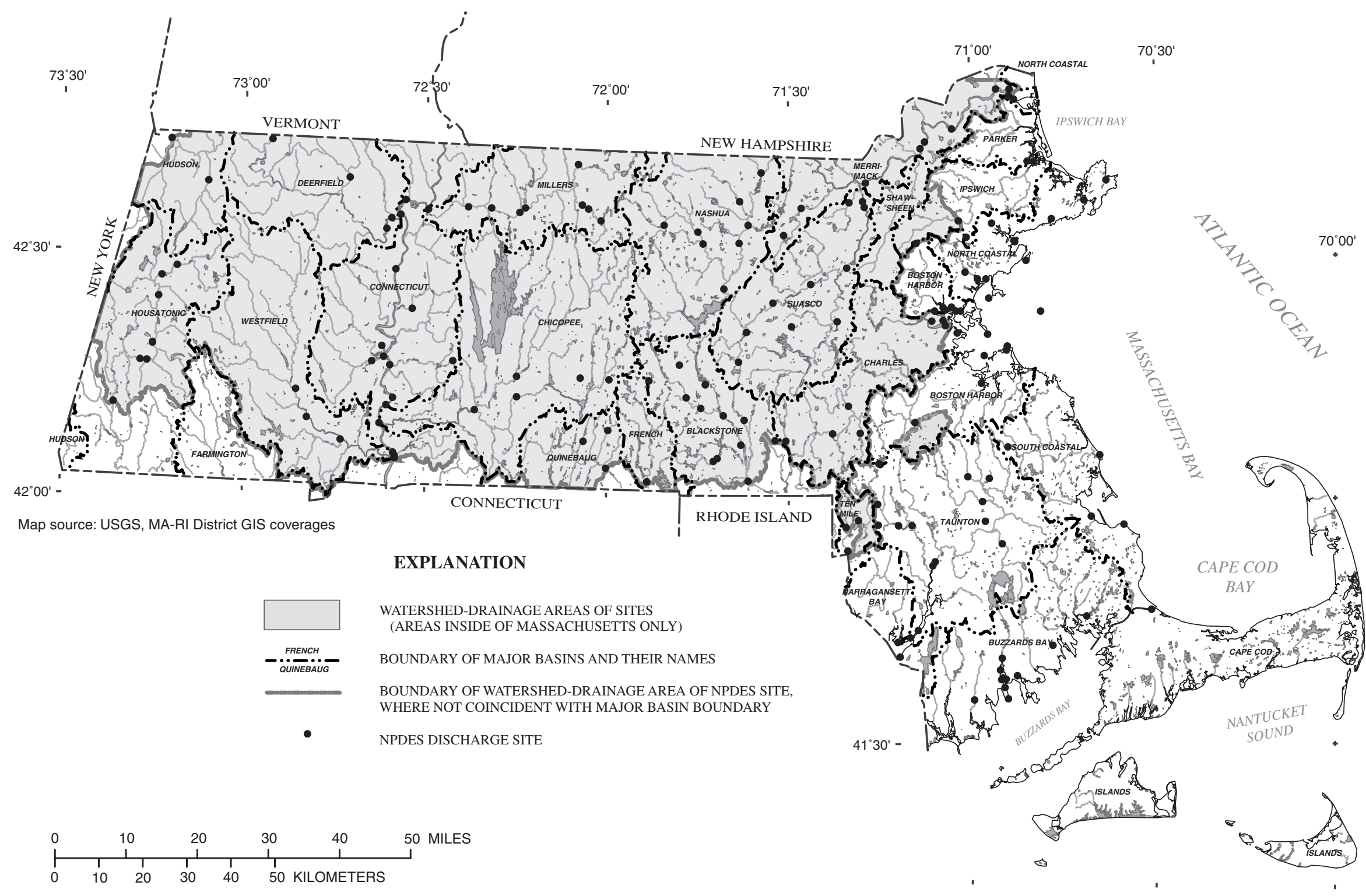

Figure 8. Locations and watershed-drainage areas of permitted major discharge sites within the National Pollutant Discharge Elimination System (NPDES) in Massachusetts for potential water-quality monitoring. Discharge sites in the Buzzards Bay and North Coastal Basins and sites discharging to coastal waters may be represented by more than one discharge location; drainage areas in the Buzzards Bay, North Coastal, and Taunton Basins are not shown. 
Table 11. Distribution of major discharge sites within the National Pollutant Discharge Elimination System among major river basins and stream orders in Massachusetts

[Density of discharge sites: Based on basin areas within Massachusetts; --, no sites or not determined]

\begin{tabular}{|c|c|c|c|c|c|c|c|c|c|}
\hline \multirow{3}{*}{ Major basin } & \multicolumn{8}{|c|}{ Number of discharge sites } & \multirow{3}{*}{$\begin{array}{l}\text { Density of } \\
\text { discharge } \\
\text { sites, in sites } \\
\text { per square } \\
\text { mile }\end{array}$} \\
\hline & \multicolumn{6}{|c|}{ Stream order } & \multirow{2}{*}{$\begin{array}{l}\text { Coastal sites or other } \\
\text { sites for which } \\
\text { stream order was not } \\
\text { determined }\end{array}$} & \multirow{2}{*}{ Total } & \\
\hline & 1 & 2 & 3 & 4 & 5 & $6-7$ & & & \\
\hline 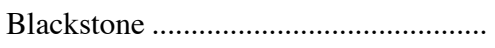 & -- & 3 & 2 & 1 & 5 & 1 & -- & 12 & 0.036 \\
\hline $\begin{array}{l}\text { Boston Harbor (Mystic, Neponset, } \\
\text { Weymouth, and Weir) }\end{array}$ & 1 & -- & -- & -- & 1 & -- & 13 & 15 & .051 \\
\hline 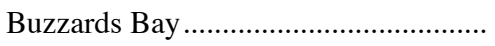 & -- & -- & -- & -- & -- & -- & 9 & 9 & -- \\
\hline 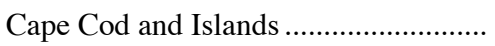 & -- & -- & -- & -- & -- & -- & 1 & 1 & .002 \\
\hline 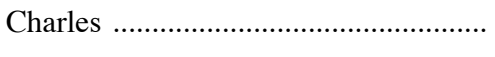 & -- & -- & -- & 2 & 2 & 1 & -- & 5 & .016 \\
\hline 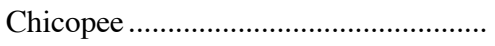 & 1 & 1 & -- & -- & -- & 3 & -- & 5 & .007 \\
\hline 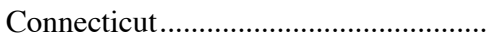 & 1 & -- & 1 & 1 & 4 & 8 & -- & 15 & .022 \\
\hline 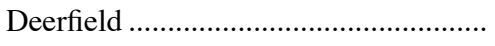 & -- & -- & 1 & 2 & & 1 & -- & 4 & .012 \\
\hline 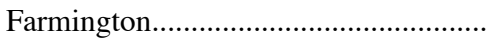 & -- & -- & -- & -- & -- & -- & -- & -- & -- \\
\hline French & -- & -- & -- & -- & 1 & -- & -- & 1 & .011 \\
\hline 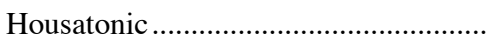 & -- & -- & -- & 2 & 6 & -- & -- & 8 & .016 \\
\hline 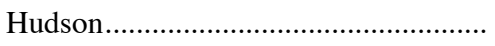 & -- & -- & -- & 1 & 1 & -- & -- & 2 & .010 \\
\hline 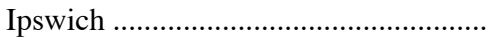 & 1 & 1 & -- & 1 & -- & -- & -- & 3 & .019 \\
\hline 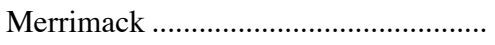 & 1 & 1 & -- & 1 & -- & 6 & 1 & 10 & .036 \\
\hline 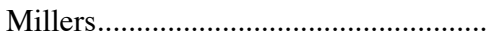 & -- & -- & -- & 3 & -- & 6 & -- & 9 & .029 \\
\hline Narragansett and Mt. Hope Bay ........... & -- & -- & -- & -- & -- & -- & 2 & 2 & .018 \\
\hline 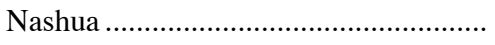 & -- & -- & 1 & -- & 4 & 3 & -- & 8 & .018 \\
\hline North Coastal............................................ & -- & -- & -- & -- & -- & -- & 10 & 10 & -- \\
\hline 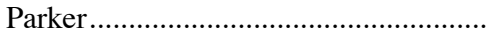 & -- & -- & -- & -- & -- & -- & -- & -- & -- \\
\hline 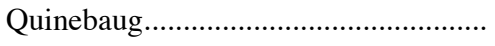 & -- & -- & 1 & 1 & -- & 1 & -- & 3 & .020 \\
\hline 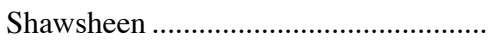 & -- & -- & -- & -- & -- & -- & -- & -- & -- \\
\hline 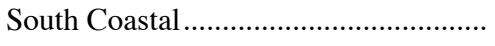 & 2 & -- & -- & -- & -- & -- & 2 & 4 & .021 \\
\hline SuAsCo (Assabet, Concord, and & & & & & & & & & \\
\hline Sudbury) ............................................ & 3 & 1 & -- & 2 & 3 & 1 & -- & 10 & .025 \\
\hline Taunton & 1 & -- & 2 & 3 & 2 & 1 & 4 & 13 & .025 \\
\hline 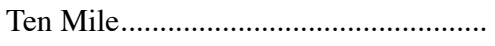 & -- & -- & -- & -- & -- & -- & 3 & 3 & .062 \\
\hline 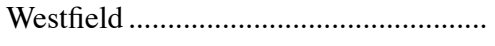 & -- & -- & -- & -- & 3 & -- & -- & 3 & .006 \\
\hline 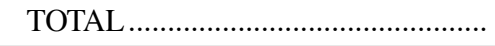 & 11 & 7 & 8 & 20 & 32 & 32 & 45 & 155 & 0.024 \\
\hline
\end{tabular}

suitable sampling sites might not be available for some discharge sites. Continuous flow data are needed to calculate contaminant loads; thus, if flow measurements could not be made at or near the site, or if the site were not close enough to a streamflow gage such that intermittent measurements could be related to a continuous record, loads could not be determined. In addition, isokinetic depth- and width-integrated sampling would likely be needed, which in general is best implemented by experienced water-quality personnel. More generally, sampling and analyses by facility per- sonnel or contractors may result in data that are not of sufficient comparability or quality to meet information needs. Well-defined protocols for sample collection, handling, and analysis, including perhaps the use of one or a small number of laboratories for all analyses, and rigorous quality control procedures would be needed. Even with these requirements, data collected by multiple, private entities may not be comparable among sites or over time at individual sites or be of sufficient quality such that contaminant loads could be calculated at all sampling sites. 


\section{SUMMARY AND CONCLUSIONS}

A water-quality monitoring program is proposed that would provide data to meet multiple information needs of Massachusetts agencies and others concerned with the quality of the State's water resources. The program design was guided by the information needs of the Massachusetts Department of Environmental Protection, Division of Watershed Management (DEP/DWM), which include mandates of the Clean Water Act (CWA) and Massachusetts Watershed Initiative (MWI) activities, and by input from many organizations involved in water-quality monitoring in the State. The program has several components or tiers, which are defined in terms of specific monitoring objectives, and is focused on inland surface waters. The objective of Tier I of the monitoring program is to provide a periodic assessment of the water-quality status of the State's surface and ground waters, as is required by section 305(b) of the CWA. The objective of Tier II is to determine loads of contaminants carried by major rivers in Massachusetts at strategic locations, such as at the mouths of major rivers and at State boundaries. Targeted monitoring programs for various objectives, such as the listing of impaired water bodies required by section 303(d) of the CWA, the identification of causes and sources of impairment for 303(d) and 305(b) purposes, and hot-spot monitoring for pollution source identification, compose Tier III of the statewide monitoring program. A fourth monitoring Tier is needed for the development of Total Maximum Daily Loads for specific impaired waters, but is not described in this report. Monitoring for compliance with regulations and permits, such as the National Pollutant Discharge Elimination System (NPDES) permits, is a possible fifth tier that might be modified to provide ambient water-quality data as well as compliance data.

To guide development of the monitoring program design, a review was conducted of general principles of network design, including monitoring objectives and approaches, and of ongoing monitoring activities of Massachusetts state agencies. A clear definition of objectives for the monitoring program is a first and necessary step in network design. Monitoring approaches, which comprise the details of how waterquality measurements will be made, are chosen to answer the water-quality questions posed by the program objectives. Monitoring approaches can be defined in terms of the time period of the measurements (short-term, long-term, or rotating), the method of site selection (targeted or probabilistic), the types of measurements made (for example, physical, chemical, or biological), the type of water resource being monitored (for example, stream, lake, or ground water), and the use of the monitoring results. Monitoring methods include fixed-station monitoring, which is a type of monitoring in which the same sites are repeatedly sampled at regular time intervals for a long period of time. Fixed-station monitoring and flow data typically are needed to estimate mass fluxes or constituent loads, as in Tier II of the proposed monitoring program; this is not the best approach for a large-scale assessment of water-resource conditions, as is needed for Tier I of the proposed program. Short-term (synoptic) surveys that incorporate probabilistic designs are more appropriate for large-scale assessments.

Ongoing monitoring programs by State agencies include (1) lake sampling, fish-toxics monitoring, measurements of benthic macroinvertebrates, and some water-chemistry monitoring by DEP/DWM, (2) lake monitoring by DEM in State parks, (3) reservoir, reservoir tributary, and coastal river sampling for bacteria and water-chemistry by the Metropolitan District Commission and the Massachusetts Water Resources Authority, (4) bacteria and physical monitoring in coastal waters by the Division of Marine Fisheries and fish community surveys by the Division of Fisheries and Wildlife of the Department of Fisheries, Wildlife, and Environmental Law Enforcement, (5) ground-water monitoring for highway-runoff contaminants by the Massachusetts Highway Department, and (6) diverse monitoring activities of many local volunteer groups. Many of these activities would provide useful data for components of the statewide monitoring program, but none has the monitoring approach, geographic coverage, sampling density, or sampling parameters that would provide information to meet all the information needs of DEP/DWM, the MWI teams, and USEPA. The review of ongoing monitoring programs demonstrates the need for the development of a statewide monitoring program such as the one described in this report.

The proposed monitoring program developed for Tier I objectives consists of a basin-based assessment of existing surface-water-quality conditions with respect to State water-quality standards and the designated uses of water bodies. Requirements for a Tier I program that reflects CWA mandates, are that it be statewide in scale, comprehensive (all water bodies in the State are assessed), and repeated at regular 
intervals. Another goal is improvement in the 305(b) assessment, through an increase in the number of stream miles and lake acres assessed and a reduction in the historical bias toward problem areas. Several approaches for this tier and their associated resource requirements were considered. Information collected in the Neponset Basin in Eastern Massachusetts, which was used as a pilot area for the MWI in the early 1990s, was used in the investigation of these approaches. GIS-based procedures were developed to inventory streams and lakes in the basin for a comprehensive assessment. Resources required for an exhaustive approach, in which every stream segment and lake in the basin is assessed and data are collected to evaluate nearly all applicable water-quality standards, were estimated to be about 2,660 personnel-days or 12 fulltime equivalents (FTEs) for field sample collection and processing and about 4,700 laboratory analyses. These estimates are for the Neponset Basin alone, which has less than one-half of one of the average area of the 27 major basins $\left(300 \mathrm{mi}^{2}\right)$ and less than one-third of the average area of the basin areas assessed by the MWI teams $\left(400 \mathrm{mi}^{2}\right)$. Thus, for statewide implementation, in which five major basins are assessed per year, perhaps 10 times the Neponset estimates would be needed, or about 120 FTEs for sample collection and processing and about 47,000 analyses; in all likelihood, more than double the personnel resources would be needed when project planning, field preparation, data management and analysis, and other aspects of the program are included. Thus, resource requirements for a comprehensive assessment of all water bodies using this exhaustive approach are much greater than could be realistically expended.

During the 1994 MWI pilot assessment of the basin, about one-half of the total stream miles were assessed for their designated uses, with a sampling density that was considerably less than that proposed for a systematic, exhaustive assessment of streams and lakes in the basin. All fourth- and fifth-order were assessed for most designated uses; the fraction of thirdorder streams assessed varied from 15 to 85 percent, by use; and less than one-half of second-order streams and less than one-third of first-order streams were assessed for any use. About one- to three-fourths of significant (larger than 5 acres) lakes in the basin were assessed for designated uses; lake assessments were based on limited data that resulted in impairment only being assessed for important uses of aquatic life and primary contact recreation. Analysis of the Neponset Basin and of the MWI pilot demonstrated that resource-limitation problems will always be posed by the large number of sites needed in order for all the small streams in a basin to be sampled (about half of stream miles in the Neponset Basin were headwater or first-order streams) and the need for repeated site visits to assess some uses. Thus, a monitoring program is proposed in which (a) probabilistic monitoring of small streams is combined with the deterministic or targeted monitoring of large streams and (b) deterministic or probabilistic monitoring of lakes may be supplemented with more intensive sampling in lakes of special interest. Small streams, including first-, second-, and third-order streams, are assessed probabilistically for the aquatic life and recreational uses. Depending on the resources expended, comprehensive estimates of these uses for small streams could be made on a state-wide basis only or for individual basins also. For large streams, including fourth-, fifth, and some third-order streams, nearly all designated uses would be assessed. Lakes larger than 10 acres are assessed for aquatic life use and trophic status.

The combined probabilistic-deterministic program would provide information to meet CWA requirements and provide data for other information needs of Massachusetts regulatory agencies and MWI teams. It would be implemented on schedule with the 5-year rotating-basin cycle of the MWI, probably in the MWI's research and assessment years. Managementlevel decisions would be needed with respect to program objectives and sampling density for the probabilistic component of the program, about whether estimates of use support for small streams are needed on the statewide scale only or for individual basins also. With the statewide estimate for small streams only, about 30 FTEs for field sample collection and processing and about 10,500 laboratory analyses would be needed; this assumes that five basins, each of which requires about twice the effort as the Neponset, are assessed per year. Additional time for field preparation and data management could double these requirements to about 60 FTEs, with several additional FTEs needed for program administration, planning, site selection, and obtaining permissions. Although they are much less than the requirements for the exhaustive approach, these resource requirements are substantial. They could be reduced by eliminating or reducing assessment of some designated uses that require intensive sampling, 
such as the recreational use for small streams or frequent sampling of lakes for trophic status, or by using a probabilistic approach for lakes.

Volunteer monitoring could be used in several ways to enhance the proposed program for Tier I monitoring or to offset the resource requirements for field data collection. Volunteer monitoring, coordinated through the MWI teams, could be used to conduct biomonitoring or collect bacteria samples at additional sites in basins where individual status estimates for small streams are needed; these estimates could be less rigorous if less sophisticated biomonitoring protocols were followed by the volunteer groups than by agency personnel. Volunteer monitoring of additional sites on large streams could be used to increase the number of third-order streams that are deterministically monitored or to increase the sampling density on mainstem reaches, most likely for aquatic life (water chemistry sampling) or recreational (bacteria sampling) uses. For lakes, volunteer monitoring could be used to increase or maintain the measurement frequency for trophicstatus indicators, to conduct more intensive assessments for some lakes, or to sample lakes of special interest deterministically if a probabilistic approach for lakes generally is taken.

For Tier II, a fixed-station sampling network to determine contaminant loads carried by major rivers, a total of 19 sampling sites are proposed. The sites are located primarily at or near existing streamflow gages in 17 of the 27 major basins in Massachusetts. Sampling at these sites would provide information on contaminant loads from 67 percent of the total land area of the State. The remaining unsampled areas of the State would be primarily coastal areas, which are drained by many small streams. Resource limitations would preclude including all these streams in a loads network. A limited number of sites in small coastal watersheds also could be sampled for a sufficient time (several years) to characterize loads from the watersheds, however, then discontinued and relocated elsewhere in the coastal area. Loads from some areas between the coast and the inland limit of tidal influence will not be determinable without developing sitespecific, non-standard methods for flow measurement (through dams, for example), or modelling. Resource requirements for Tier II of the network were estimated at about 2 FTEs for water-quality sample collection, with additional time needed for field preparation, data analysis and resources for the management, and the installation, operation, and maintenance of any new streamflow gages.

Targeted programs of Tier III of the proposed network are described primarily in terms of strategies for hot-spot monitoring, that is, monitoring to identify pollution sources. These strategies are investigated using an analysis of the bacteria sampling program of the 1994 Neponset Basin assessment. In that study, data from 41 sites were used to identify leaking sewer lines and failed septic systems, as well as stormwater runoff, as general sources of bacteria contamination in the basin and to confirm that bacteria were a basinwide problem. The bacteria source for a specific impaired reach was identified in only one instance out of 29 impairments, using infrastructure investigation by a town rather than by additional water-quality sampling. An analysis of watershed areas of the sampling sites found little relation between bacteria concentrations and land uses expected to be bacteria sources. These analyses illustrate the difficulties that can arise when a single monitoring design is used to address multiple, sometimes partly conflicting, monitoring objectives. They also demonstrated that effective programs for hot-spot monitoring are based on substantial knowledge of suspected problem areas and on site and contaminant characteristics, information that commonly is compiled by MWI teams and also could be provided to some extent by Tier I of the monitoring program. Approaches for hot-spot monitoring programs, in terms of sampling parameters and density, require site-specific development and resource requirements that cannot be defined in advance.

Finally, the distribution of major National Pollutant Discharge Elimination System (NPDES) sites in Massachusetts was evaluated to determine the usefulness of these sites for the collection of ambient water-quality data. Locations of 155 sites were reviewed. The sites were well distributed geographically among basins, but were located primarily on large rivers, with two-thirds or more on fourth- or higher order streams. Use of these sites for a statewide assessment of stream-water quality, such as needed for Tier I of the monitoring program, would yield estimates of use support that were biased towards large streams. The targeted approach to site selection also would mean that monitoring could not be extrapolated to unsampled streams. With assumptions of $3 \mathrm{mi}$ of assessed stream per site for first- through third-order streams and $5 \mathrm{mi}$ per site for fourth- and higher order streams, a total of 
$553 \mathrm{mi}$, or less than 10 percent of the perennial stream miles in the State, would be assessed by sampling major NPDES sites. NPDES sites might be more suited to sampling for loads or Tier II objectives than for a statewide status assessment. Watersheds of major NPDES sites, where they could be determined, account for about 70 percent of the total land area of Massachusetts. These sites may not be optimally located in terms of the loads objectives, however; they also would require review and perhaps sampling by experienced water-quality personnel. It might also be difficult to design and implement sampling protocols for use by multiple private entities to ensure adequate data quality and comparability.

In summary, the water-quality monitoring program described in this report contains several components that would provide information to meet many of the water-quality information needs of the Massachusetts state agencies and others concerned about water resources in the State. The components are complementary in many ways but are not interchangeable, and each component requires a substantial investment of personnel time, laboratory analyses, and other resources. Several components must be developed on site-specific bases, and available resources will place important constraints on all aspects of the program. The water-quality information needs to which components of the proposed program are addressed must be carefully evaluated and prioritized, so that monitoring resources are efficiently and effectively deployed in accordance with the critical tasks of protecting and managing the water resources of Massachusetts.

\section{REFERENCES}

Ackerman, M.T., 1989, Compilation of lakes, ponds, reservoirs and impoundments relative to the Massachusetts Clean Lakes Program: Westborough, Mass., Massachusetts Department of Environmental Quality Engineering, Division of Water Pollution Control, TSB.

Ackerman, M.T., Batiuk, R.A., and Beaudoin, T.M., 1984, Compilation of lakes, ponds, reservoirs and impoundments relative to the Massachusetts Lake Classification Program: Boston, Mass., Massachusetts Department of Environmental Quality Engineering, Publication number 13786-216-30-8-84-CR, 196 p.
Bladys, Stanley, III, Raines, T.H., Mansfield, B.L., and Sandlin, J.T., 1998, Urban stormwater quality, eventmean concentrations, and estimates of stormwater pollutant loads, Dallas-Fort Worth Area, Texas, 1992-93: U.S. Geological Survey Water-Resources Investigations Report 98-4158, 51 p.

Bowie, G.L., Mills, W.B., Porcella, D.B., Campbell, C.L., Pagenkopf, J.R., Rupp, G.L., Johnson, K.M., Chan, P.W.H., Gherini, S.A., and Chamberlin, C.E., 1985, Rates, constants, and kinetics formulations in surface water quality modeling ( $2 \mathrm{~d}$ ed.): Athens, Ga., U.S. Environmental Protection Agency, Office of Research and Development, EPA/600/3-85/040, 455 p.

Carlson, R.E., 1977, A trophic state index for lakes: Limnology and Oceanography, v. 22, p. 361-368.

Christensen, V.G., Jien, Xiaodong, and Ziegler, A.C., 2000, Regression analysis and real-time water-quality monitoring to estimate constituent concentrations, loads, and yields in the Little Arkansas River, SouthCentral Kansas, 1995-99: U.S. Geological Survey Water-Resources Investigations Report 00-4126, 36 p.

Commonwealth of Massachusetts, 1997, Summary of water quality 1996: Worcester, Mass., Commonwealth of Massachusetts, Executive Office of Environmental Affairs, Department of Environmental Protection, Division of Watershed Management, $135 \mathrm{p}$.

1998, Summary of water quality 1998: Worcester, Mass., Commonwealth of Massachusetts, Executive Office of Environmental Affairs, Department of Environmental Protection, Division of Watershed Management, $145 \mathrm{p}$.

1999, Final Massachusetts section 303(d) list of waters: Worcester, Mass., Commonwealth of Massachusetts, Executive Office of Environmental Affairs, Department of Environmental Protection, Division of Watershed Management, $131 \mathrm{p}$.

Cuffney, T.F., Gurtz, M.E., and Meador, M.R., 1993, Methods for collecting benthic invertebrate samples as part of the National Water-Quality Assessment Program: U.S. Geological Survey Open-File Report 93403, 66 p.

Dates, G., Dickens, S., and Tremblay, M., 2000, Volunteer monitoring program development: Report to the Massachusetts Executive Office of Environmental Affairs, Oct. 13, 2000, variously paginated.

Edwards, T.K., and Glysson, G.D., 1999, Field methods for measurement of fluvial sediment: U.S. Geological Survey Techniques of Water-Resources Investigations, Book 3, Ch. C2, 89 p.

Gilbert, R.O., 1987, Statistical Methods for Environmental Pollution Monitoring: New York, Van Nostrand Reinhold Company, 319 p. 
Gordon, N.D., McMahon, T.A., Finlayson, B.L., 1992 , Stream hydrology - An introduction for ecologists: New York, John Wiley and Sons, 526 p.

Halliwell, D.B., Kimball, W.A., and Screpetis, A.J., 1982, Massachusetts stream classification program: Part I: Inventory of rivers and streams: Westborough, Mass., Massachusetts Department of Environmental Quality Engineering, Division of Water Pollution Control, Technical Services Branch, 125 p., and associated documentation.

Helsel, D.R., and Hirsch, R.M., 1992, Statistical Methods in Water Resources: Amsterdam, The Netherlands, Elsevier Science Publishing Company, 522 p.

Hooper, R.P., Goolsby, D.A., Rickert, D.A., and McKenzie, S.W., 1997, NASQAN, Monitoring the water quality of the Nation's large rivers, A river-basin perspective on monitoring water quality: U.S. Geological Survey Fact sheet FS-055-97, 6 p.

Intergovernmental Task Force on Monitoring Water Quality, 1995a, The strategy for improving water-quality monitoring in the United States--Final report of the Intergovernmental Task Force of Monitoring Water Quality: U.S. Geological Survey Open-File Report 95742, accessed February 24, 2000 at URL http://water.usgs.gov/wicp/lopez.main.html.

1995b, The strategy for improving water-quality monitoring in the United States - Technical Appendixes--Final report of the Intergovernmental Task Force of Monitoring Water Quality: Reston, Va., U.S. Geological Survey, 117 p.

James, William, Huber, W.C., Dickinson, R.E., and James, W.R.C., eds, 1998, Water Systems Models Hydrology, Users Guide to SWMM4 RUNOFF and supporting modules: Guelph, Ontario, Canada, CHI and University of Guelph, 283 p.

Kennedy, L.E., O’Shea, L.K., Dunn, Jr., W.J., and LeVangie, D., 1995, The Neponset River Watershed 1994 resource assessment report: North Grafton and Boston, Mass., Massachusetts Department of Environmental Protection, Office of Watershed Management, variously paginated.

Kentucky Division of Water, 1997, Kentucky Watershed Management Framework Document: accessed May 19, 2000, at http://water.nr.state.ky.us/dow/wa/default.htm.

Lopes, T.J., and Price, C.V., 1997, Study plan for urban stream indicator sites of the National Water-Quality Assessment Program: U.S. Geological Survey Openfile Report 97-25, 15 p.

Massachusetts Department of Environmental Protection, 1997, About the Bureau of Resource Protection: accessed February 11, 2000, at URL http://www.state.ma.us/dep/brp/aboutbrp.htm.
MassGIS, 1997, MassGIS Datalayer descriptions and guide to user services: Boston, Mass., Massachusetts Executive Office of Environmental Affairs, March 1997, $131 \mathrm{p}$.

2000a, MassGIS Data Viewer Overview, March 2000: accessed June 19, 2000, at URL http:// www.magnet.state.ma.us/mgis/vwrover.htm. 2000b, MassGIS Data Viewer Watershed Analyst, March 2000: accessed June 19, 2000, at URL http://www.magnet.state.ma.us/mgis/vwr_wa1.htm.

Parker, G.W., and DeSimone, L.A., 1992, Estimating reaeration coefficients for low-slope streams in Massachusetts and New York, 1985-88: U.S. Geological Survey Water-Resources Investigations Report 91-4188, 34 p.

Parker, G.W., and Gay, F.B., 1987, Equation to estimate reaeration coefficients in Massachusetts streams: U.S. Geological Survey Water-Resources Investigations Report 86-4111, 34 p.

Persaud, D., Jaagumagi, R., and Hayton, A., 1993, Guidelines for the protection and management of aquatic sediment quality in Ontario: Ontario, Canada, Queen's Printer for Ontario, Ontario Ministry of the Environment, Water Resources Branch.

Roth, N.E., Chaillou, J.C., and Gaughan, Michael, 1997a, Guide to using 1995 Maryland biological stream survey data: prepared by Versar, Inc., Columbia, Md., for Maryland Department of Natural Resources, Annapolis, Md., May 1997, variously paginated

Roth, N.E., Southerland, M.T., Chaillou, J.C., Volstad, J.H., Weisberg, S.B., Wilson, H.T., Heimbuch, D.G., and Seibel, J.C., 1997b, Maryland biological stream survey: ecological status of non-tidal streams in six basins sampled in 1995: prepared by Versar, Inc., Columbia, Md., for Maryland Department of Natural Resources, Annapolis, Md., May 1997, variously paginated.

Sanders, T.G., Ward, R.C., Loftis, J.C., Steele, T.D., Adrian, D.D., and Yevjevick, Vujica, 1987, Design of Networks for Monitoring Water Quality: Littleton, Colorado, Water Resource Publications, 328 p.

Scheaffer, R.L., and McClave, J.T., 1982, Statistics for Engineers: Boston, Duxbury Press, 475 p.

Smith, R.A., Alexander, R.B., and Wolman, M.G., 1987, Analysis and interpretation of water-quality trends in major U.S. rivers, 1974-81: U.S. Geological Survey Water-Supply Paper 2307, 25 p.

U.S. Environmental Protection Agency, 1997a, Guidelines for preparation of comprehensive state water-quality assessments (305(b) reports) and electronic updates: report contents: Washington, D.C., U.S. Environmental Protection Agency, Office of Water, EPA-841-B-97002A, variously paginated. 
U.S. Environmental Protection Agency, 1997b, Guidelines for preparation of comprehensive state water-quality assessments (305(b) reports) and electronic updates: supplement: Washington, D.C., U.S. Environmental Protection Agency, Office of Water, EPA-841-B-97002B, variously paginated.

1997c, NPDES Permit Program-General Information: U.S. Environmental Protection Agency, Office of Wastewater Management, accessed April 24, 2000, at URL http://www.epa.gov/owm/gen2.htm. 1998a, Envirofacts Warehouse, 1998, accessed November and December 1998, at URL http://www.epa.gov/9966/enviroded/owa) . 1998b, Lake and reservoir bioassessment and biocritera, Technical Guidance Document: U.S. Environmental Protection Agency, Office of Water, EPA-841-B-98-007, variously paginated.

1999, Summary of state biological assessment programs for streams and rivers: U.S. Environmental Protection Agency, Office of Water, EPA230-R-96-007, accessed February 11, 2000, at URL http://www.epa/gov/owow/monitoring/bio.

2000, About the NPDES storm water program: U.S. Environmental Protection Agency, Office of Wastewater Management, accessed April 24, 2000, at URL http://www.epa.gov/owm/sw/about/index.htm.
U.S. Geological Survey, 2000, Water resources of New Hampshire and Vermont, Study design of the New England Coastal Basins and preliminary monitoring plans, accessed November 9, 2000, at URL http://nh.water.usgs.gov/CurrentProjects/nawqa/nawqa web2.htm.

Weiskel, P.K., Howes, B.L., and Heufelder, G.R., 1996, Coliform contamination of a coastal embayment: sources and transport pathways: Environmental Science and Technology, v. 30, no. 6, p. 1872-1881.

Waldron, M.C., Steeves., P.A., and Finn, J.T., 2001, Use of thematic mapper imagery to assess water quality, trophic state, and macrophyte distributions in Massachusetts lakes: U.S. Geological Survey WaterResources Investigations Report 01-4016, 40 p.

Ward, R.C., Loftis, J.C., and McBride, G.B., 1990, Design of water quality monitoring systems: New York, Van Nostrand Reinhold, $231 \mathrm{p}$.

Wood, Pamla, Shipp, Alison, and Colten, Lee, 1999, 19992000 Strategic monitoring plan, Salt \& Licking Basin Management Unit, Kentucky: accessed May 19, 2000, at URL http://water.nr.state.ky.us/dow/mon2.htm. 
APPENDIX - Geographic Information System (GIS) and other computer-based procedures used in the monitoring design for the Neponset Basin 



\section{GENERAL COMMENTS}

The procedures outlined below describe the steps that can be followed to inventory streams and lakes in a basin as needed for the Tier I network design of the proposed statewide monitoring program. The inventory for streams involves segmenting the streams at tributary confluences, intersections with lakes, and point-source discharges. Digital data used in these procedures is the 1:25,000-scale hydrography made available with the MassGIS Watershed Data Viewer (MassGIS, 2000a). Most of the procedures are carried out using ESRI's ARC/INFO Geographic Information System (GIS) software or the Watershed Viewer, which is run in ESRI's ARCVIEW software. Knowledge of and facility with these software packages is assumed in the steps described.

An overview of the procedures is as follows:

A. First, the centerline stream data layer for the basin was edited, in ARC/INFO, to generate a data layer of points that define the boundaries between stream segments and downstream of lakes. The approach used to complete this task was guided by the need to delineate watersheds for each stream segment and lake included in the inventory (these were needed for a stratified-sampling design based on watershed characteristics, which was not in fact implemented in the final monitoring design). Consequently, streams were segmented in ARC/INFO at locations that were at small distances (30 meters) upstream from the actual points of tributary confluences and of intersections with lake boundaries, so that separate watersheds could be accurately delineated for each segment with the Watershed Analyst.

B. The data layer of points defining stream-segment boundaries was used to create "events" along the centerline hydrography for the basin using the Watershed Analyst in ARCVIEW. Events are points along a stream network that are referenced to the network in terms of distance along a stream reach and upstream/downstream order. Unique identification numbers were given to the stream segments, and an event table was created that provided information on the distance of each point along its reach. These data were later manipulated in a spreadsheet to determine individual stream segment lengths (see item 4, below).

C. Watersheds, which were saved as ARCVIEW shape files, were delineated from each event. These represent watersheds for all stream segments and lakes in the basin. The application within the Watershed Analyst that was used to delineate watersheds from a point-event table (that is, in batch mode), rather than interactively and individually, were specifically created for this project by Aleda Freeman at MassGIS.

D. Stream segment data from (B) were manipulated in a spreadsheet to generate population statistics such as total stream miles in the basin, length per segment, and so on. 
1. SEGMENTATION OF STREAM HYDROGRAPHY IN THE NEPONSET BASIN USING ARC/INFO

\subsection{PREPARATION OF THE STREAM COVERAGE}

1.1.1. Copy the centerline coverage (called "centerline") for the basin of interest out of the "watershed" library of the MassGIS Watershed Data Viewer. This is the coverage created by MassGIS that represents hydrography as a routed network.

1.1.2. Remove all arcs that do not connect to the main network (these arcs represent streams that flow into sink holes such as a kettle pond).

1.1.3. Drop the node, route, and section feature classes from the centerline coverage using 'Dropfeatures'.

1.1.4. Build the centerline coverage as a polygon coverage to complement the line attributes that still exist. The purpose of this step is to allow identification of braided areas in the centerline coverage.

1.1.5. Review the polygons that exist in the centerline coverage. There should be two types of polygons, which will be separately handled:

- Large polygons are typically stream networks that share the same headwaters (generally a wetland). These areas are left as is.

- Small polygons are typically areas inside a braided stream. Identify these areas on a plot; these areas will need special manipulation in a subsequent step (1.2.13b, below)

1.1.6. Drop the polygon feature class. The edited centerline coverage that results will be a line coverage containing only connected streams.

\subsection{SEGMENTING STREAMS BASED ON TRIBUTARY CONFLUENCES}

1.2.1. Make a copy of the edited centerline coverage. Retain both copies; continue steps described below on one copy.

1.2.2. Remove intermittent streams. Save them in a separate coverage.

1.2.3. Drop the line feature class; then re-build the coverage as lines. Calculate the attribute "covername-id" equal to 1 for all lines.

1.2.4. Remove pseudo nodes using the 'Eliminate' command.

1.2.5. Remove any dangling arcs with lengths less than 100 meters (328 feet). Save them in a separate coverage.

1.2.6. Run the 'Eliminate' command again to remove pseudo nodes left over after the removal of dangling arcs less than 100 meters (there may be a few pseudo nodes remaining on very long arcs).

1.2.7. Build the coverage as nodes. Add two items to the node attribute table (NAT) using the 'Additem' command: NODE_TYPE (4 5 B) and NODE_CODE (2 2 I).

1.2.8. Create a coverage of all lakes and ponds in the watershed by selecting them out of the hydrography coverage ("hydro") that is located in the "watershed" library. The hydrography coverage is the traditional 1:25,000-scale digital data representing hydrography as shown on USGS topographic quadrangles. The lake coverage created in this step will be used to identify confluences in the centerline coverage that occur within lakes (step 1.2.9, below). 
1.2.9. Calculate values for NODE_TYPE and NODE_CODE as follows:

NODE_TYPE: $1=$ dangles; $2=$ pseudo nodes; $3=$ all remaining nodes (nodes of type 3 will be at the tributary confluences).

NODE_CODE:

$1=$ pseudo nodes (same as node_type $=2$ )

$2=$ nodes at confluences within lakes (Use the 'Overlap' option of the 'Reselect' command in ArcPlot, with the coverage of lakes created in step 1.2.8, above, as the overlap coverage.)

$3=$ dangles (same as node_type $=1$ except for the node at the mouth of the network).

$4=$ dangles in lakes (Repeat the 'Reselect/Overlap' procedures with the lakes coverage for NODE_CODE $=2$, then reselect for NODE_TYPE $=1$. These nodes are uniquely identified because they are headwater nodes.)

$5=$ node at mouth of basin

$8=$ all remaining nodes (confluences). These nodes will be used in step 2.1.4, below, to define stream segments.

1.2.10. Run the 'Buffer' command on the nodes, using 30 meters as the buffer distance, to create circular polygons of 30-meter radii around all nodes.

1.2.11. Reselect all nodes with a NODE_CODE $=8$. Within this selected set, reselect all buffers which overlap the selected nodes (Use the 'Reselect' command in ARC/PLOT), using the coverage created in step 1.2.10 ("coverbuff") as the buffer coverage and the coverage being developed ("coverage") as the input coverage, as follows "Reselect coverbuff poly overlap coverage node'). Create a new coverage of the selected buffer polygons, using the 'Writeselect' command.

1.2.12. Run the 'Identity' command using the edited centerline coverage as the input coverage and the coverage of buffer polygons as the identity coverage (use 'LINE' for feature class). This is done to create nodes where the buffer boundary intersects the centerline.

1.2.13. Select all new nodes created in step 1.2.12 (NODE_CODE $=0)$ and calculate NODE_CODE $=99$. Quality-assure these nodes on the computer screen by "zooming into" various areas in the map.

Check for two problems:

a. Areas where there are multiple river sections (for example, canals, mud flats, or marshland). In these areas, select nodes that may overlap one another or cluster. Keep some representative nodes for these areas, coded as NODE_CODE $=99$. Calculate the remainder to NODE_CODE $=6$.

b. Nodes that are on braided-stream sections (identified and plotted in step 1.1.5; these areas include cranberry bogs). Calculate NODE_CODE $=7$ for these. 
1.2.14. Run the 'Nodepoint' command to create points from the nodes in the coverage. In the output point coverage, select all points with NODE_CODE values not equal to 99 and delete them. The remaining points are the population for defining stream segments by tributary confluences.

\subsection{INVENTORYING LAKES AND SEGMENTING STREAM HYDROGRAPHY BASED ON LAKES:}

1.3.1. Preparation of the lakes coverage

1.3.1.1. From the coverage of lakes created in step (1.2.8), above, create a new coverage by reselecting all polygons larger than 5 acres $(20,235$ square meters). NOTE: This coverage, of lakes larger than 5 acres, is the coverage used as an inventory of lakes in the basin for the monitoring program.

1.3.1.2. Check that all lake polygons lie on the centerline network of perennial and intermittent streams. Do this by comparing the coverage of lakes larger than 5 acres with the edited centerline coverage retained in step 1.2.1 that included intermittent streams. In rare instances, lakes may not lie on the centerline network, and may need special handling to delineate their watersheds (see step 3, below).

1.3.1.3. Review the lakes polygons in the coverages on screen to identify single lake bodies that are represented by two adjacent polygons. These may occur at quadrangle boundaries (for example, Bird Pond in the Neponset Basin) or where lakes are partly coded as lake/open water and partly as lake/wetland. Review these lakes on the topo quadrangles and dissolve the internal arcs as appropriate. This step also may be completed in step 2.1.2.2.

1.3.2. Build the edited centerline coverage with intermittent streams, retained in step (1.2.1), above, as a node coverage (complimenting the line feature class). Add an item to the node attribute table, LAKE_NODE ( $111 \mathrm{I})$. Calculate all nodes to LAKE_NODE $=1$.

1.3.3. 'Clip' the centerline data later using the coverage of lakes larger than 5 acres as the clip coverage, specifying 'Line' for the feature class option.

1.3.4. New nodes will be created from this clip. Reselect all nodes where LAKE_NODE $=0$ and calculate LAKE_NODE $=2$ for these new nodes.

1.3.5. Run the 'Buffer' command on the coverage using 'Node' as the feature type and 30 meters as the buffer distance. Check the output coverage for overlapping buffer-zone polygons. Overlapping buffer polygons would occur in areas where two lakes, less than 60 meters apart, are connected by a stream. Document these areas for a subsequent step. 
1.3.6. Reselect (in ARC/PLOT) all nodes from the clipped coverage with a LAKE_NODE $=2$, then reselect all polygons from the buffer zones coverage that overlap the selected set. Create a new coverage of these buffer zones using the 'Writeselect' command.

1.3.7. Prepare the final line coverage created in the section 1.2, above, for inclusion of lake nodes by adding the intermittent stream segments and small arc lengths, which were removed in steps 1.2.2 and 1.2.5, to the coverage with the 'Append' command. Select all nodes where NODE_CODE $=0$ (these are new nodes produced during the append procedure), and calculate NODE_CODE $=9$ for these nodes. The intermittent stream segments and small arc segments are added back to the coverage being developed at this stage, to allow for nodes to be determined for lakes that lie on these stream reaches.

Note that items in both the arc (AAT) and node (NAT attribute tables must match before running 'Append'. If they do not match, "dummy" items will need to be added to the coverage that lacks attributes present in the other coverage. This is necessary because items in the two coverages must be identical to the 'Append' command to work correctly; if items are not identical, items present in one coverage and not in the other will be eliminated when the 'Append' command is run. The only non-default items that it is important to retain are NODE_TYPE and NODE_CODE items in the NAT. Build the output coverage from the Append procedure as LINE and NODE feature classes (check to see if all items exist in the NAT).

1.3.8. Run the 'Identity' command using the final line coverage created in step 1.3.7, and the output coverage of buffer polygons created in step 1.3.6.

In the output coverage from the 'Identity' procedure, reselect the nodes that overlap the coverage of lakes larger than 5 acres. Within this selected set, reselect the nodes with NODE_CODE $=0$. Calculate the NODE_CODE $=10$ for this subset of nodes. Then, use the 'Nselect' to "flop" the selected set, which will select all remaining nodes with NODE_CODE $=0$ (these will be all nodes that are more than 30 meters outside of lake boundaries). Calculate NODE_CODE $=98$ for these nodes.

1.3.9. Run the 'Nodepoint' command. In the output point coverage, select out all points with NODE_CODE values not equal to 98 and delete these nodes. The remaining points are the population for defining stream segments by significant lakes.

1.3.10. Combine the coverage of points created in step (3.9) with lakes with the coverage of points created in (2) with tributary confluences, using the 'Append' command.

Check for:

a. Points that fall within estuaries for coastal watersheds (the centerline extends out to the ocean). Delete these points. 
b. Locations where lakes are very close to confluences. Any points that fall closer than 20 meters to the lake or the confluence should be deleted. This will occur only infrequently.

A quick on-screen review or check plot of the coverage should be sufficient to locate these occurrences (nodes lying close to one another also can be found using the reach codes of the Watershed Analyst).

c. Locations where two lakes are very close to one another identified in step 3.5). Add a point in the middle of the two lakes as close to the centerline as possible.

\subsection{SEGMENTING STREAM HYDROGRAPHY BASED ON POINT SOURCES}

1.4.1. Create or use an existing point coverage of the point-source sites in the watershed. Review the coverage for accuracy and compare it to the centerline coverage of streams. If a site does not lie on the centerline network, determine its correct location and move the point to that location.

1.4.2. Run the 'Nodepoint' command and calculate NODE_CODE $=97$ for all points.

1.4.3. 'Append' the point coverage created in step 1.4.2 for NPDES locations to the point coverage based on lakes and confluences created in step 1.3.10. Check for match among attributes in the two coverages as described in step 1.3.7.

\subsection{CREATING THE FINAL POINT COVERAGE OF SEGMENT BOUNDARIES}

1.5.1. Add an attribute "ID" to the point coverage created in step 1.4.3. Calculate ID equal to the coverage\# attribute; this will define a unique identification number for each node.

1.5.2. Run the 'Addxy' command on the point coverage. The coverage now is ready to create events on the centerline hydrography with the Watershed Analyst.

2. DETEMINING UPSTREAM/DOWNSTREAM ORDER AND ANCILLARY INFORMATION FOR STREAM SEGMENTS BY CREATING POINT EVENTS ON THE CENTERLINE HYDROGRAPHY USING ARCVIEW AND THE WATERSHED ANALYST

2.1. Open the MassGIS Data Viewer project in ARCVIEW. Load the extension 'Spatial Analyst', followed by the extension 'MassGIS Watershed Delineator'.

2.2. Preset a tolerances option, using options under the 'MassGIS-Hydro' menu:

"Change snap tolerance for finding route"-This tolerance sets the maximum distance from which a point will snap to the centerline network. Because the points are already on the centerline network, this tolerance can be set at 1 .

2.3. Add the centerline theme for the basin of interest and the point coverage finalized in step 1.5.2 to the view. With both themes active, run the 'MassGIS-

Hydro' menu option 'Make point event table from coverage' to create a point event table. This option prompts the user to select the attribute that should be 
used to number the events. The attribute "ID," created in step 1.5.1, was used to set the event identification number (ID), ensuring a unique ID for each event.

The point event table created in this step will provide the following information: the ID of the point event, the MassGIS reach code for the stream reach on which the event is located, and the distance along that reach (measured from its downstream end) to the event. This information will be used in step 5, below, to determine stream segment lengths.

2.4. Run the 'Display event table' from the 'MassGIS-Hydro' menu, which creates a theme and displays the point events.

3. DELINEATE WATERSHEDS FOR STREAM SEGMENTS AND LAKES USING ARCVIEW AND THE WATERSHED ANALYST

3.1. Open the MassGIS Data Viewer project in ARCVIEW. Load the extension 'Spatial Analyst', followed by the extension 'MassGIS Watershed Delineator.'

3.2. Preset a tolerances option, using options under the 'MassGIS-Hydro' menu:

"Change snap tolerance for delineation"-This tolerance sets a search distance from the cell of elevation grid in the Watershed Analyst that is selected (in this case, the cell that the event lies within) to the lowest cell within the tolerance distance to start the delineation (the watershed delineation will start from this cell). Because the centerline network was used to create the events used for delineation, the events lie directly upon the centerline network. This allows snap tolerances for watershed delineation to be set at very low values. Low snap tolerances are especially important at confluences, where a snap tolerance greater than 2 elevation-grid cells could result in the wrong confluence being chosen as the starting point for the delineated watershed. However, although the events all are on the stream centerline, the selected elevation-grid cell corresponding to an event will not always correspond to the cell where the stream lies, as described by the grid elevations (although the stream locations based on the centerline and on the grid elevations should be close, due to enhancement processing of the source DEMs for the elevation grid). Thus, some leeway should be allowed for this tolerance. Because the confluence events are located 30 meters from the actual confluences, 15 to 20 meters is an appropriate value for this tolerance.

3.3. With the centerline theme and the event theme active, select the "Upstream Watershed for Points in Batch Mode" tool, which is a button on the Watershed Analyst pull down indicated with a "W" and three diamond shaped symbols (for more information on how to use the Watershed Analyst, see the MassGIS Home page: http://www.magnet.state.ma.us/mgis/.

3.4. The user is asked several questions before the batch processing begins, including whether to use either an input attribute to name the output watershed shape files (each watershed is output to a separate shape file) or a default value. For this project, the identification number determined as the coverage attribute "ID" in step 1.5.1 and used as the point event ID in step 2.1.3 was used. The user also is asked to choose attributes for inclusion in each output shape file. The following attributes were included: the ID of the point event, the distance or "measure" along the stream route that the point event occurs, measured 
from the beginning of the route, and the area, in square meters, of the delineated watershed. The ID and measure attributes are are important to include, because they maintain a relationship between the output watershed and both the event and the centerline network. (The ID and measure attributes also occur in the point event table.)

3.5. Delineated watersheds should be quality-assured with on-screen review. For the Neponset Basin work, 95 percent of the watersheds were found to be accurately delineated. Inaccurate delineations occurred in a few instances where, for example, an event was too close to an upstream lake, and the delineated watershed incorrectly cut partly across the lake surface instead of running outside of the lake boundary (enhancements to the watershed delineation application have been proposed to correct this problem). Because of these few inaccuracies, the quality-assurance review is recommended.

3.6. If lakes larger than 5 acres include any lake not on the centerline, their watersheds will need to be separately delineated. Procedures for this will depend of the specific circumstances of each lake.

4. MANIPULALATION OF STREAM SEGMENT DATA TO OBTAIN STREAM AND LAKE POPULATION STATISTICS IN A SPREADSHEET

GENERAL COMMENT: The spreadsheet steps described below were developed simultaneously with the GIS procedures described in steps 1 through 3, above. The procedures described effectively process the data generated by the GIS work to obtain the information needed for the Neponset network design and analysis; however, they do not represent the most efficient approach to obtaining this information.

The GIS procedures described in steps 1-3 result in the definition of segments along the centerline hydrography that can be uniquely identified by their downstream endpoints (IDs). The centerline segments include (i) segments along streams between confluences ("internal stream segments") and (ii) segments extending through lakes (lake segments). The centerline segments also include (iii) 40-meter segments along mainstem reaches that extend up- and downstream from confluences with tributaries, and (iv) 20-meter segments along each tributary extending upstream from its confluence a higher order or mainstem stream. Segment types (iii) and (iv) resulted because of the need to divide the centerline hydrography small distances up- and downstream from confluences, rather than at their exact locations, so that watersheds could be delineated. Similarly, lake segments extend about 20 meters up- and(or) downstream from the lake inlet and outlet, respectively (separate nodes at the lake boundaries themselves were not created). The confluence segments and the 20-meter lengths within lake segments represent parts of the physical stream segments of interest for the stream population inventory, and their lengths must be "added back" to the internal stream segments to obtain true lengths of physical stream segments in the basin.

The re-accumulation of stream segments for the stream population inventory from confluence segments and parts of lake segments was accomplished through the spreadsheet steps described below. A more efficient approach would be to complete this work within ARCVIEW. An application within the Watershed Analyst could be developed that would make use of the option to "Create a linear event table from the point event table" in the Watershed Analyst. Input to the application would be point events that were located at confluences and at lake inlets and outlets, rather than at the up- and downstream points needed for watershed delineation. A linear event table 
summarizes the length of river meters from an event to the next downstream event, and includes the upstream point event ID for each linear event. The linear event table would efficiently produce the information on stream-segment length and upstream/downstream order needed for an accurate stream population inventory in a basin. Work was begun on this application by USGS and MassGIS, but was not completed as part of the current project.

\subsection{STREAMS}

\subsubsection{A spreadsheet was constructed containing:}

a. event ID

b. reach code - the number MassGIS uses to uniquely code each continuous length of stream in the centerline coverage

c. measure - the distance, in meters, along the reach from its beginning to the location of the event)

d. NODE_TYPE - S, stream; L, lake defined based

e. order - strahler stream order

f. watershed area

Items $\mathrm{a}, \mathrm{b}, \mathrm{c}$, and $\mathrm{f}$ were obtained from the ARCVIEW shape files containing the watershed delineations; they also could have been derived from the point event table. Items $\mathrm{d}$ and e were obtained from the ARC/INFO coverage by listing attribute items NODE_TYPE and ORDER

4.1.2. Data were sorted on (1) reach code and (2) measure, in ascending order. In this way, the centerline segments are ordered sequentially from downstream to upstream along a reach.

4.1.3. Values for lengths of all centerline segments (LENGTH1), in meters, were determined by subtracting the measure of the upstream event ID from the measure of the event ID for the segment of interest.

4.1.4. Centerline segments representing confluence segments (types iii and iv, above), were identified, by their lengths (about 20 or 40 meters) and relative positions between longer segments. The identification of these segments was checked on a plot of centerline hydrography and event locations.

4.1.5. Final values for lengths of inventoried stream segments were determined:

a. For internal stream segments bounded by confluence segments, lengths were determined by adding the lengths of the internal stream segments to the length of the adjacent confluence segments (or one-half of the lengths of an adjacent confluence segments that extended across the confluences).

b. For internal stream segments bounded by lake segments, lengths were determined by adding 20 meters to the length of the internal stream segments.

4.1.6. Final values for lengths of inventoried lake segments also were determined, subtracting 20 meters from the initial length value (step 4.1.3) for lake inlet and outlet segments; these procedures were verified as appropriate by reviewing a plot to the centerline hydrography, lake 
polygons, and event locations. However, this information, on length of the centerline hydrography as intersected by the lake boundary, was not used for in the current network design or analysis for characterizing lakes in the basin.

4.1.7. Final values for inventoried, physical stream and lake segments of length, stream order, and watershed area, were output to a second spreadsheet for calculation of summary statistics and further analysis.

4.1.8. For lakes, values of lake area, determined by listing the AREA attribute of the coverage of lakes greater than five acres created in step 1.3.1, were added to the spreadsheet created in step 4.1.7.

\subsection{LAKES}

4.2.1. A spreadsheet was constructed by copying items listed in step 4.1.1 for all IDs where NODE_TYPE was equal to L (for lake).

4.2.2. Lake areas (polygon areas) were added, by matching ARC/INFO polygon IDs, obtained from the.PAT file of the coverage of lakes larger than 5 acres.

4.2.3. Lake polygons and IDs were reviewed on a plot to identify lakes represented by two polygons in the coverage. Generally, these occurred when part of the lake was represented by open water and part by wetland. These were combined in the spreadsheet inventory as appropriate. Note that as similar review occurred at step 1.1.1.3 